Portland State University

PDXScholar

Winter 4-18-2013

\title{
Statistical Analysis of Stormwater Device Testing Protocols in Portland, Oregon
}

Zahra Kavianpour Isfahani

Portland State University

Follow this and additional works at: https://pdxscholar.library.pdx.edu/open_access_etds

Part of the Water Resource Management Commons

Let us know how access to this document benefits you.

\section{Recommended Citation}

Kavianpour Isfahani, Zahra, "Statistical Analysis of Stormwater Device Testing Protocols in Portland, Oregon" (2013). Dissertations and Theses. Paper 676.

https://doi.org/10.15760/etd.676

This Thesis is brought to you for free and open access. It has been accepted for inclusion in Dissertations and Theses by an authorized administrator of PDXScholar. Please contact us if we can make this document more accessible: pdxscholar@pdx.edu. 
Statistical Analysis of Stormwater Device Testing Protocols in Portland, Oregon

$$
\text { by }
$$

\title{
Zahra Kavianpour Isfahani
}

A thesis submitted in partial fulfillment of the requirements for the degree of

\author{
Master of Science \\ in \\ Civil and Environmental Engineering
}

Thesis Committee:

William Fish, Chair

Scott Wells

Hamid Moradkhani

Portland State University 2013 


\begin{abstract}
Stormwater treatment is commonly performed with a combination of approaches including the utilization of natural systems and engineered devices. Before using a proprietary treatment instrument it is required to verify its performance and efficiency in reducing different pollution components including the TSS. Different states have developed strategies and regulations for accepting new instruments. In this thesis the stormwater management plan of the City of Portland, Oregon (2008), is analyzed in order to improve the current regulations. These rules apply to new technologies which are proposed by vendors to be used in Portland's stormwater treatment plans. Each requirement which should be met by the applying vendors is thoroughly analyzed followed by a comparison with the Stormwater management plan(2008)regulations of the state of Washington the so called Technology Assessment Plan-Ecology TAPE (Howie, 2011). Because of the similarities in the climate and land use between these two testing frameworks in order to evaluate the potential applicability of data submitted by vendors who had devices approved by Washington, to be utilized by Portland. The treatment of total suspended solids (TSS) is the focus of this thesis since it is central to the testing process and since most of the other pollutions are attached to TSS and will get treated if TSS is treated. The overall analysis shows that Portland adopts more restrictive requirements on the characterization of stormwater event samples to be treated by a technological instrument while Washington's restriction are more stringent on the efficiency of total suspended solid removal, in which it demands


higher standards on the treatment of TSS compared to Portland's efficiency requirements. In order to study practical context in which regulations are administrated by Portland, rainfall data from 66 gauges covering the period of 1980-2011 was studied and the impacts of seasonality, land use, land form, periods of no rain before and after an event and Portland's Modified Performance line on the number of accepted rain events were analyzed. The results which were accepted by state of Washington were also compared with the results accepted by the city of Portland on Portland's Standard Performance line. Our seasonality study suggests that Portland's requirements are unnecessarily restrictive which results in the disqualification of many otherwise useful stormwater events, sometimes allowing no natural events to be available for testing in dry years. The analysis of land use showed that land use has no statistically significant impact on the concentration levels of TSS, thereby indicating that land use restrictions in the testing rules could be usefully relaxed. Decreasing the interevent no-rain period significantly increases the total number of events providing sufficient data to assess the performance of treatment facilities. We also showed that many more events become suitable for performance testing if events separated by one hours or less are considered a single, longer event. Finally we identified a statistical relationship between number of forecasted accepted stormwater events and the total average daily precipitation in a given year. 
In The Name of God, The Most Compassionate and Merciful

I dedicate this thesis to my husband and my best friend, Reza, who has always been by my side, with unconditional love, help and support, encouraging me to follow what I am passionate about. To my daughter, Ava, whose presence makes me the happiest person and the proudest mother.

And to my parents and little sister, Sarah, who have always been my role models and helped me start my journey and showered me with their love and support throughout the way. 


\section{Acknowledgments}

I would like to acknowledge with my greatest thanks to my advisor, Professor William Fish for all his guidance throughout my thesis; and for introducing me to the subject which provided a new path in my studies. I would also like to thank him for his inspirational classes which introduced me to a new perspective, and from those classes I found what I was truly passionate about.

I would like to thank Mr. Guy Alvis for being available any time I had a question or needed more information. The data which are used in this study are through the efforts of Mr. Alvis.

I thank my thesis committee members Professor Scott Wells and Professor Hamid Moradkhani. They were great help for starting my new major and kindly advised me on my path. They helped me understand my abilities and interests and guided me from my very first steps in Portland State University, and for that I am deeply thankful.

My gratitude is to the Department of Civil and Engineering's staff, especially Megan Niermeyer who have always been available to help and answer questions.

I deeply thank all my family members and friends, whose support has been a reason for my confidence and efforts.

The funding for this research study was provided by the City of Portland, Bureau of Environmental Services. 


\section{Contents}

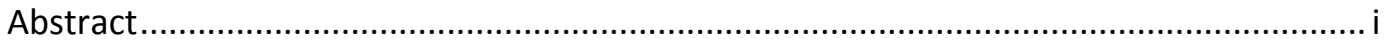

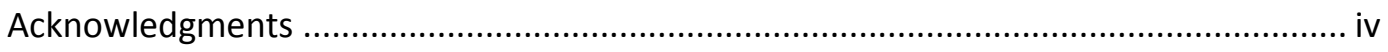

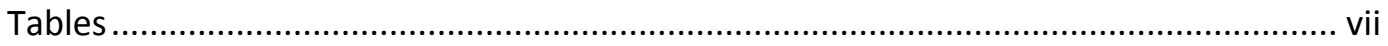

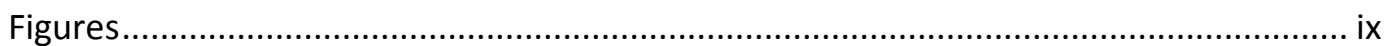

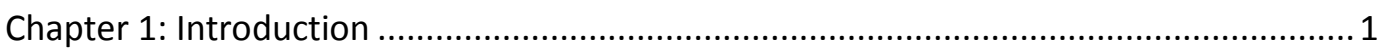

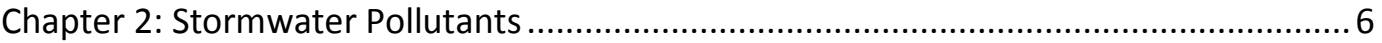

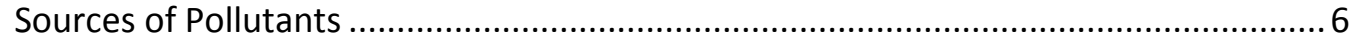

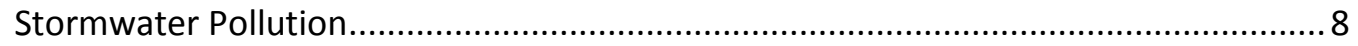

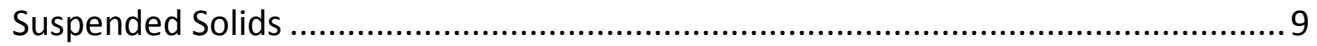

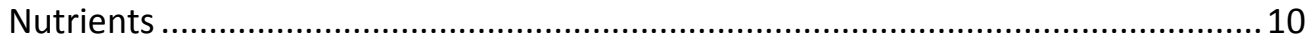

Biochemical Oxygen Demand (BOD) and Chemical Oxygen Demand (COD) ............ 10

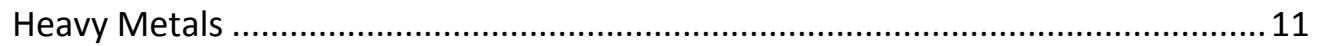

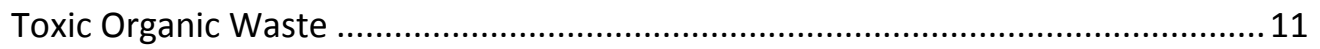

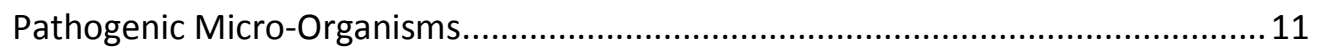

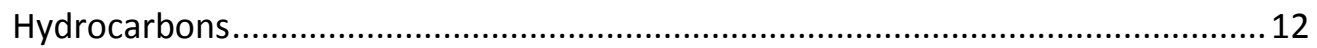

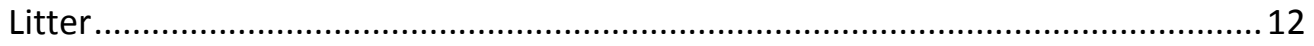

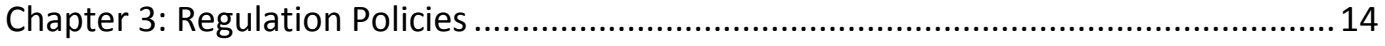

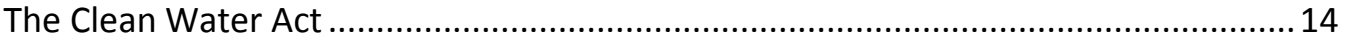

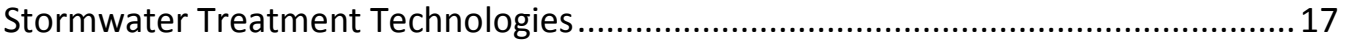

Chapter 4: Portland Stormwater Management System .................................................... 18

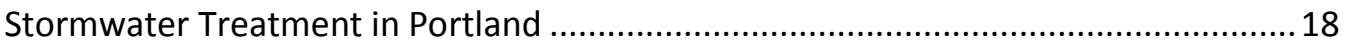

Stormwater Management Requirements of the City of Portland ...............................20

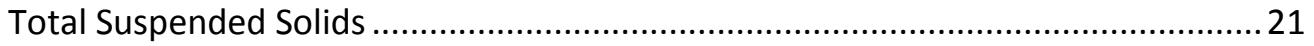

TMDL Enhanced Performance Goal .................................................................... 22 
Maintenance

Data Submission.

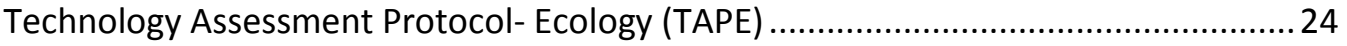

Comparing the City of Portland's Stormwater Management System and TAPE ...........24

Challenges in the Current Stormwater Treatment Policies of Portland ........................29

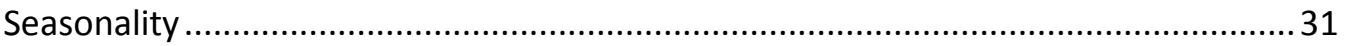

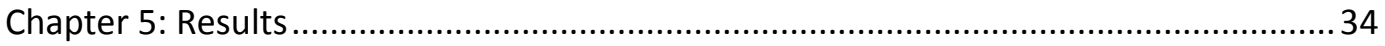

Statistical Analysis of Portland Rainfall Events for Sampling Suitability ....................... 34

Estimating the Number of Events Using the Average Daily Precipitation .................... 42

Comparing the effects of rainfall depth, intensity and duration on removal TSS efficiency

Land Use. 59

Six Hourly Duration of No Rain Before and After a Rainfall Event. .63

Connecting Events with 1 Hour Interevent Periods. 69

Portland's Modified Performance Standard Line ....................................................... 73

Part I of trisected Portland's Modified Performance standard Line........................ 78

Part II of Portland's Modified Performance standard Line ....................................... 80

Part III of Portland's Modified Performance Standard Line....................................82

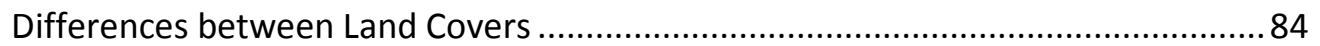

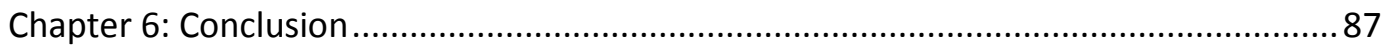

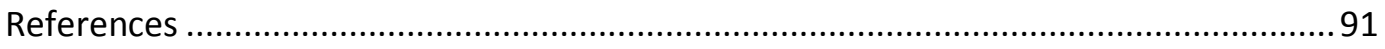

Appendix - more additional information .................................................................. 93

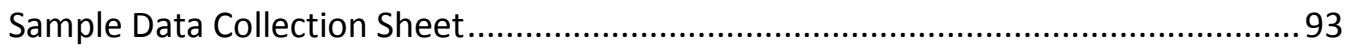

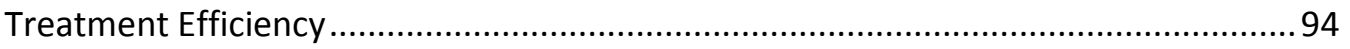

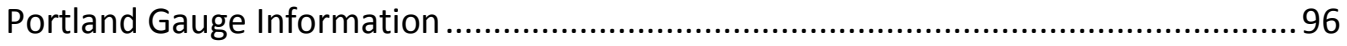

Current Approved List of Vendors by City of Portland as of April 2005 ....................... 99

Summary of Best Management Practices by City of Portland.................................... 100 


\section{Tables}

Table 1- Sources of urban pollutants at individual sites - (Minton, 2002) ................................... 7

Table 2: Observed ranges of components in stormwater .................................................... 13

Table 3: Particle size distribution removal requirements (Portland's Stormwater Management

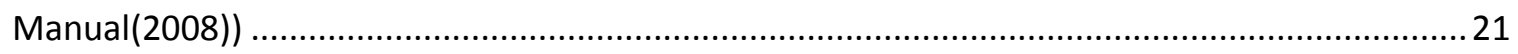

Table 4: Stormwater treatment requirements in the city of Portland versus the state of

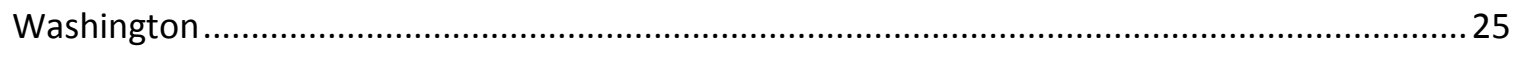

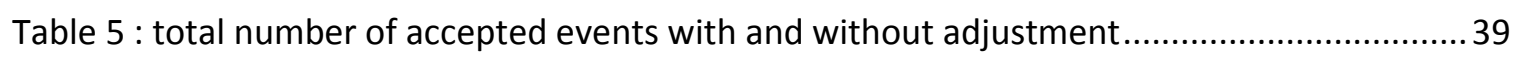

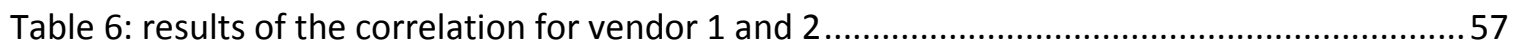

Table 7 : Difference between three land use types ( units are $\mathrm{mg} /$ Lexcept for fecal coliform

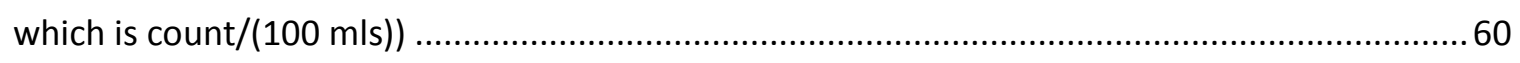

Table 8: Median and CV of TSS in the residential, mixed, commercial and open non-urban land

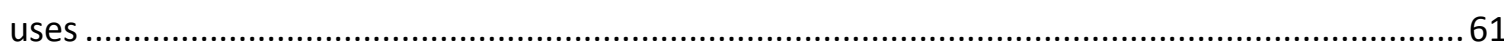

Table 9: Change in the available number of stormwater events by decreasing the no-rain duration before and after an event criterion for the dry season ............................................ 66

Table 10: Change in the available number of stormwater events by decreasing the no-rain duration before and after an event criterion for the wet season ..........................................69

Table 11: Change in the available number of stormwater events for different scenarios............72

Table 12 :Portland's Modified Performance Standard Line data points...................................... 74

Table 13: RMSE and Bias results for acceptable events by Portland in part I of Portland's

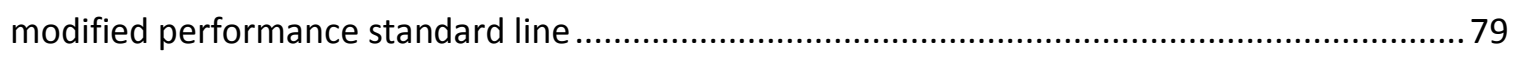


Table 14: RMSE and Bias results for acceptable events by Portland and Washington in part I of Portland's modified performance standard line. 79

Table 15: RMSE and Bias results for acceptable events by Portland in part II of Portland's modified performance standard line...... 81

Table 16: RMSE and Bias results for acceptable events by Portland and Washington in part II of Portland's modified performance standard line. 81

Table 17: RMSE and Bias results for acceptable events by Portland in part III of Portland's modified performance standard line 83

Table 18: RMSE and Bias results for acceptable events by Portland and Washington in part III of Portland's modified performance standard line. 


\section{Figures}

Figure 1: Map of Portland, Oregon with all the available gauges 30

Figure 2: Average daily precipitation intensity for all gauges for each month, 1980-2011.

Figure 3: The total number of events for all gauges in each year during the dry season 35

Figure 4: The total number of events for all gauges in each year during the wet season 36

Figure 5: Histogram of the total number of events per gauge per year during the dry

season

Figure 6: Histogram of the total number of events per gauge per year during the wet season 38

Figure 7: Histogram of the percentage of stormwater events per gauge per year during the dry season. 39

Figure 8: Histogram of the percentage of stormwater events per gauge per year during the wet season. 40

Figure 9: Number of gauges which follow the $30 \%-70 \%$ criterion compared to the total number of gauges at each year.

Figure 10: Number of gauges which follow the $30 \%-70 \%$ criterion compared to the total number of gauges at each year; when possible number of stormwater events were discarded to meet the $30 \%-70 \%$ criterion ......

Figure 11: Average daily precipitation versus the number of stormwater events in each gauge for the dry season 
Figure 12: Average daily precipitation versus the number of stormwater events in each gauge for the dry season continued 45

Figure 13: Average daily precipitation versus the number of stormwater events in each gauge for the wet season 46

Figure 14: Average daily precipitation versus the number of stormwater events in each gauge for the wet season continued 47

Figure 15: Histograms of the correlations between the average daily precipitation and the number of events for all gauges in the dry and wet seasons. 49

Figure 16: Correlation between the average number of events (Poisson $\lambda$ ) and the average daily precipitation for all gauges at each year in the dry season with a 95\% confidence interval. 51

Figure 17: Correlation between the average number of events (Poisson $\lambda$ ) and the average daily precipitation for all gauges at each year in the wet season with a 95\% confidence interval. 52 Figure 18: comparing the effects of storm depth, storm duration and antecedent dry

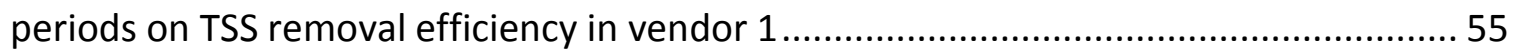

Figure 19: comparing the effects of storm depth, storm duration and storm intensity on

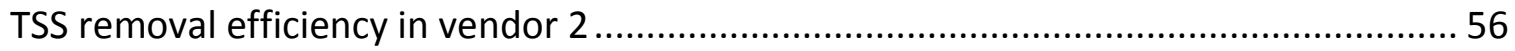
Figure 20: Variation in the event mean concentration of TSS between different land uses(USEPA, 1983) 62 
Figure 21: Histogram of the total number of events per gauge per year during the dry

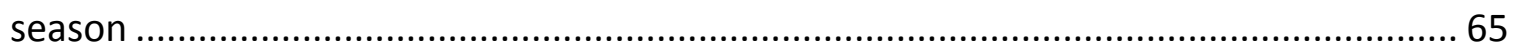

Figure 22: Histogram of the total number of events per gauge per year during the wet

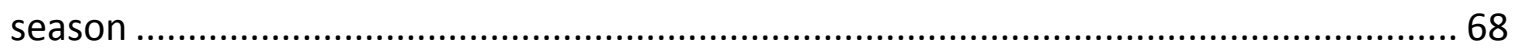

Figure 23: Histogram of the total number of events per gauge per year ..................... 71

Figure 24: Portland's Modified Performance Standard Line ..................................... 74

Figure 25: Part I of the Portland's Modified Performance standard Line ...................... 79

Figure 26: Part II of the Portland's Modified Performance standard Line ...................... 81

Figure 27: Part III of the Portland's Modified Performance standard Line ..................... 83 


\section{Chapter 1: Introduction}

In urban areas water that results from a rainfall is called stormwater. Stormwater can enter the ground, infiltrate into the aquifer and indirectly into a river, flow over land as direct surface runoff into a stream, a stormwater collection system, or evaporate. Urban and rural developments typically alter the quality of the stormwater runoff. Also, impervious surfaces, in urban areas create more runoff. As this water runs off various surfaces, it will wash pollutants and sediment with it into urban streams and rivers, polluting them and increasing the cost of clean water. Under the Clean Water Act (CWA), cities and states have now taken actions in order to make sure this runoff enter streams and rivers at an acceptable level of cleanness. [http://www.epa.gov/lawsregs/laws/cwa.html]

Portland's first sewer was built in 1864. This sewer collected sewage from homes and industrial lands and discharged them into the Willamette River with no treatment. In the early $20^{\text {th }}$ century, the public health awareness increased, citizens took action and Oregon voters initiated and passed the Water Purification and Prevention of Pollution Bill [1938, http://www.pdxcityclub.org/content/waterpurification-and-prevention-pollution-bill-state-measure-10]. In response to the 1972 CWA, the National Pollutant Discharge Elimination System (NPDES) Municipal Separate Storm Sewer System (MS4) Discharge Permit issued by the state of Oregon, Portland's stormwater management plan started to take shape. As the requirements have developed, Portland's treatment system has also evolved. Most of Portland has 
a combined sewer system, Covering both the sewage and stormwater runoff. One of the problems with the combined sewer system is that in the conditions of a high intensity rainfall, or whenever there is a sufficient stormwater runoff, the combined sewer system overflows, directly into the Willamette River, untreated.

To overcome this problem the City of Portland has increased the capacity of the combined sewers and also, since 1991, Portland has built some stormwater sewers. Stormwater sewers are very helpful, because the stormwater is not combined with the sewage, leaving more capacity for the sewage and an easier treatment for the stormwater runoff. [www.portlandonline.com]. Since the stormwater sewers are connected to the river and other water bodies, City of Portland has decided to treat these stormwater runoff in order to keep the river and water surfaces clean from pollution.

As mentioned earlier the stormwater runoff picks up pollution from the surfaces as it heads into the stormwater sewer system. These pollutions consist of sediments (suspended solids), oil and grease, dissolved solids, nutrients and organic compounds, heavy metals, such as lead, copper, cadmium and zinc(Dechesne et al., 2004). The stormwater management plan (2008) designed by the city outlines how stormwater should be treated. Also included in the plan are sustainable stormwater management systems in order to reduce pollutants in stormwater. These systems include green streets [streets with landscaped curb extensions, swales, planter strips, pervious pavement, and street trees to intercept and infiltrate stormwater] to 
address street runoff, and eco roofs [vegetated roof systems that decrease runoff and offer aesthetic, air quality, habitat, and energy benefits].

The city has developed a Stormwater Management Manual (2008) which includes all the requirements necessary for stormwater management. These outlines were to be used by any new developments and redevelopments within the city. Of primary significance to this thesis are the sections in the SWMM that define the required testing of performance of approved onsite stormwater treatment devices. However, only one proprietary treatment device has been approved for use in Portland since 1994. This restriction to one system also affects other Oregon municipalities that follow Portland guidelines.

Washington State also has a stormwater management plan(2008) called Technology Assessment Protocol-Ecology (TAPE)(Howie, 2011; Hoppin, 2008) that includes stormwater management manuals for the state of Washington. TAPE has been used statewide and has approved several different proprietary storm water treatment systems. Thus, urban stormwater management in Washington State can be implemented with a wider range of technologies than are available in Portland. Part of this thesis is concentrated on the differences between TAPE and Portland's stormwater management plan(2008), to see which one is more restricted, and what is that restriction's goal. 
The BES SWMM has the guideline a vendor needs to follow in order to submit their treatment device for consideration by the city. These restrictions on the prospective vendors can be divided in two parts. The first set of restrictions applies to the stormwater sampling methodology. This part is the prime concern of this thesis. The second set of rules defines the efficiency of the treatment and how the pollutions have been treated.

As discussed in the body of this thesis, the restrictions regarding the sampling are relatively difficult to meet. Portland is a city which gets lots of drizzles and short rain showers, yet the sampling for device approval must include many rather long events with significant interevent periods dividing them. These restrictions could cause a problem of a vendor not being able to get enough rain samples. Another constraint is that no more than $70 \%$ of the data may be in either the wet or dry seasons.

Because the city has asked for 15 sampled rain events from the prospective vendor, this means that at least five of the events must be in the dry season. This is mostly unachievable unless there is an extremely rainy dry season. BES staff has expressed a desire to determine if less restrictive event sampling rules make better sense in the context of the Portland climate, but without significantly weakening the robustness of the test finding. 
This thesis thus aims to analyze these rules, working with 30 years of precipitation data from 66 gauges in Portland area; and get statistical results which will show whether it is possible to reach these goals. The results are used to guide some proposed adjustments to these rules, and the effect of these adjustments are reviewed.

Chapter 2 of this thesis reviews storm water pollution, the origin and amount of pollutants, and problems associated with them. Chapter 3 describes regulation policies including the Clean Water Act, and the permits associated with the CWA. Chapter 4 concentrates on the City of Portland, stormwater treatment system, the regulations and requirements of Portland for vendors who want to submit theirs stormwater treatment facilities to Portland. It also discussed the similarities and differences between Portland's vendor submission requirements and State of Washington TAPE requirements. Chapter 5 presents the challenges that each sampling requirement causes, and the effect of those requirements on the number of acceptable samples. It also includes the suggested change to the current rules and the expected results of such program modifications. 


\section{Chapter 2: Stormwater Pollutants}

A number of pollutants play a big role in contaminating stormwater. These pollutants may be from different point or nonpoint sources and the amount of pollutants can vary considerably. Depending on the regulations for the region of interest, these contaminants must be treated to the required level.

\section{Sources of Pollutants}

Knowing the source of stormwater is a good indication of which pollutants and how much of them are to be expected in the stormwater. Stormwater could be polluted from multiple sources in the urban and rural areas. (Novotny et al., 1994) (Dechesne et al., 2004)

One source is atmospheric deposition which transports the pollutants produced by offsite sources. These sources could be industrial emissions, burning of fuels, and agricultural emissions such as pesticides. Atmospheric deposition can occurs in both wet and dry seasons. An example of the importance of atmospheric deposition is that the amount of metals deposited from the atmosphere is significantly higher, in comparison with the metals generated at the surfaces. Another studies found that 20 percent of the total suspended solids (TSS) were deposited from atmosphere(Sonzogni et al., 1980).

Another significant source of pollutants is tire wear from vehicles which is considered a significant source of metals. In a study in San Francisco Bay, it was 
found that about 6 percent of the zinc and half of copper that was entering the bay was from the wear of brake pads. (Armstrong and Consultants, 1994; Beckwith et al., 1986) Table 1 has a list of major pollutant sources and the pollutants associated with them. Knowing and understanding these sources can help us prevent them and treat them.

Table 1- Sources of urban pollutants at individual sites - (Minton, 2002)

\begin{tabular}{|c|c|}
\hline Source & Major pollutants \\
\hline $\begin{array}{l}\text { Atmospheric } \\
\text { deposition }\end{array}$ & $\begin{array}{l}\text { From urban and urban areas: fine particles, phosphorus, } \\
\text { ammonia, nitrate, pesticides, petroleum products, toxic } \\
\text { organics and metals }\end{array}$ \\
\hline Litter and leaf fall & $\begin{array}{l}\text { Personal and commercial debris discarded to roadways } \\
\text { and parking lots such as plastics, paper, cans and food; } \\
\text { leaves and organic debris from roadside and parking lot } \\
\text { trees: BOD, nitrogen, phosphorus, humic organics, metals }\end{array}$ \\
\hline $\begin{array}{l}\text { Residential and } \\
\text { roadside landscape } \\
\text { maintenance }\end{array}$ & $\begin{array}{l}\text { Phosphorus and nitrogen, pesticides and herbicides, } \\
\text { dissolved organics from soil amendments }\end{array}$ \\
\hline $\begin{array}{l}\text { Urban wildlife and } \\
\text { pets }\end{array}$ & Bacteria phosphorus and nitrogen \\
\hline $\begin{array}{l}\text { Transportation } \\
\text { vehicles }\end{array}$ & $\begin{array}{l}\text { Fuels; brake drum and tire wear; body rust: fine particles, } \\
\text { metals in particular zinc, copper, cadmium, lead, and } \\
\text { chromium; and petroleum products such as oil and grease } \\
\text { and PAH }\end{array}$ \\
\hline $\begin{array}{l}\text { Pavement and } \\
\text { pavement } \\
\text { maintenance }\end{array}$ & $\begin{array}{l}\text { Temperature modification, petroleum derivatives from } \\
\text { asphalt }\end{array}$ \\
\hline Pavement deicing & $\begin{array}{l}\text { Chlorides, sulfates, organics from acetate deicers, coarse } \\
\text { sediments, and cyanide }\end{array}$ \\
\hline Building exteriors & Galvanized metals, chipped and eroded paints, corrosion \\
\hline
\end{tabular}


of surfaces accelerated by acid rain, metals

Industrial businesses Varies widely by the industry. Includes the pollutants commonly contributed by other sources but may also include those less commonly detected in general urban runoff or at concentrations greater than normally found in pollutions from inappropriate connections; petroleum products, phenols, solvents, metals

Commercial

businesses

Residential activities

Site development

Public infrastructure
Parked vehicles; improperly disposed refuse such as discarded food, used cooking oil and grease, and packaging materials; internal drains improperly connected to the storm system: metals, BOD , bacteria, phosphorus, nitrogen, petroleum products, zinc and bacteria

Landscaping, pest control, moss control, vehicle maintenance, painting, wood preservation: pesticides and herbicides, phosphorus, nitrogen, petroleum products, zinc and bacteria

High pH from fresh concrete surfaces; petroleum products from fresh asphalt and spills; organics and particles from landscaping materials; eroded sediment and associated constituents like phosphorus; pollutants associated with improperly disposed construction materials like fresh concrete and paints; cement from preparation of exposed aggregate concrete

Metals from galvanized stormwater drain systems; metals and petroleum products from maintenance shops; bacteria, nitrogen, phosphorus, and organics from exfiltration or overflowing sanitary sewers

\section{$\underline{\text { Stormwater Pollution }}$}

Precipitation events in urbanized areas generate overland flow known as stormwater. Depending on the land cover, stormwater picks up pollutants and dirt as it flows into a storm sewer system, a combined sewer system, or directly to a 
river or some other receiving water body. When the amount of a material dissolved or suspended is at a concentration higher than what is considered "natural" for the receiving water, it may be considered a pollutant. (Chiew et al., 1997)

Growth of cities and urban areas creates more impervious surfaces; impervious surfaces result in more stormwater runoff and potentially more contaminated stormwater runoff. Stormwater contaminant typically includes suspended solids, oil and grease and solid or dissolved contaminants such as toxic metals or trace organics. Depending on where it flows to, the stormwater then will pollute the rivers, lakes and other water bodies and also the storm sewer system. The stormwater volume in urban areas is usually higher than in farmlands because there is considerably less of soil infiltration. However, stormwater from farm lands and soils may also be polluted. Some of the pollutants which are the main concern and should usually be treated if higher than regulations are listed below(Novotny et al., 1994; Chebbo, 1999; Tsihrintzis and Hamid, 1997):

\section{Suspended Solids}

Suspended sediments or total suspended solids (TSS) are one of the most important pollutants. Sediments could cause a hazard for the aquatic life which is in need of light, by dimming the water. Usually there are other pollutants attached to

suspended solids. Suspended solids are the reason for cloudiness or turbidity of water. Sediments can also cause reduced water channel capacity. Excess TSS 
increases the need for filtration in water treatment facilities. Peak sediment removal rates of $60 \frac{g r}{d a y}$ have been recorded for highway surfaces (Ellis et al., 1986)

\section{Nutrients}

Nutrients mainly consist of phosphorus and nitrogen. Higher levels of these elements in the water bodies will upset the natural balance. These nutrients may be dissolved (phosphate (PO4), ammonia (NH3, NH4), oxidized nitrogen (NO2, NO3)) or they may be attached to sediment particles. Excess nutrients can cause eutrophication of receiving water. In addition, drinking large amounts of nitrates and nitrites are particularly threatening to infants (for example, when mixed in formula) (EPA). In urban areas, nutrients usually come from industrial discharges, fertilizers, animal waste and detergents.

\section{Biochemical Oxygen Demand (BOD) and Chemical Oxygen Demand (COD)}

Biochemical oxygen demand (BOD) and Chemical Oxygen Demand (COD) levels in urban stormwater are two to five times higher than levels in streams and natural water bodies. Elevated BOD and COD induce lower oxygen levels which could kill aquatic life and encourage anaerobic micro-organism growth. Under anaerobic conditions, nutrients and metals attached to sediments are released faster. (Fabricius, 2005; Chiew et al., 1997). 


\section{$\underline{\text { Heavy Metals }}$}

Metals such as zinc ( $\mathrm{Zn})$, lead (Pb), and copper usually originate from vehicles, roads, or rusty pipes. They are toxic to humans, animals and birds, they may cause an immediate effect due to their high concentration or they could build up and eventually cause chronic illness. The amount of these metals is usually greater in urban areas, due to their sources. Some of these metals are also transferred up the food chain (Weibel et al., 1964; Chiew et al., 1997; Makepeace et al., 1995; Pitt et al., 1995). Peak sediment removal rates of metal loadings reaching

$22 \frac{m g}{d a y}$ and $24 \frac{m g}{d a y}$ have been recorded for zinc $(\mathrm{Zn})$ and lead $(\mathrm{Pb})$, respectively (Harrop et al., 1983). Atmospheric deposition occurs when pollutants are transferred from the air to the earth's surface. (Wong et al., 2000; Taebi and Droste, 2004; Bruland et al., 1974)

\section{Toxic Organic Waste}

Toxic organic waste is usually traced to herbicides and pesticides, and sometimes to industrial chemicals. If the toxic organic waste accumulates in the ecosystem, they will cause toxicity.

\section{Pathogenic Micro-Organisms}

Pathogenic microorganisms include viruses, bacteria and protozoa. They are usually found in soil, decaying vegetation, and animal waste. They are dangerous to 
humans and may cause hepatitis and gastrointestinal diseases. They are commonly found in high levels after a heavy storm (Chiew et al., 1997; Taebi and Droste, 2004).

\section{Hydrocarbons}

Hydrocarbons are usually traced back to oil and grease from vehicles and machinery and surfactants in detergents. They can cause short term toxicity problems.

\section{Litter}

Plastic bags, bottles, paper, and any other rubbish is unpleasant, smelly and cause harm to aquatic life.

Stormwater pollution may come from a point (where the pollution is discharged from one location, like a factory) be or non-point (where the pollution is discharged from a large area and flows to the stormwater sewer or water bodies from multiple sources. (Chiew et al., 1997)

Table 2 shows the ranges of observed concentrations of many components of stormwater collected from a review of over 100 references. (Makepeace et al., 1995) Keep in mind that the lowest observed concentration in table 2 is a little misleading because it is presumed that some concentrations are always detected. 
Table 2: Observed ranges of components in stormwater

\begin{tabular}{|c|c|c|c|}
\hline Component & Range & Means & Concern \\
\hline Aldrin + dieldrin & $5 E-6-1 E-4$ & & Minor \\
\hline Alkalinity & $8-1273$ & $46-56$ & No \\
\hline Ammonia & $0.01-4.3$ & & \\
\hline Benzene & $0.0035-0.013$ & & No \\
\hline BOD & $1-7700$ & $9-31$ & Minor \\
\hline Cadmium & $0.00005-13.73$ & $0.0003-0.011$ & Major \\
\hline Calcium & $0.04-2113.8$ & $4.8-26.5$ & No \\
\hline Chromium & $0.001-2.3$ & $0.010-0.23$ & Major \\
\hline Copper & $0.00006-1.41$ & $0.0065-0.15$ & Major \\
\hline Dissolved oxygen & $0-14$ & & Major \\
\hline Dissolved solids & $76-2792$ & & \\
\hline DDT & $<0.0001$ & & No \\
\hline Enterococci & $3-1.4 \mathrm{E} 6$ & & Major \\
\hline Fecal coliform & $0.2-1.9 \mathrm{E} 6$ & & Major \\
\hline Hardness & $12-11000$ & & No \\
\hline Iron & $0.08-440$ & $1-12$ & Major \\
\hline Lead & $0.00057-26$ & $0.02-1.56$ & Major \\
\hline Nickel & $0.001-49$ & $0.006-0.15$ & Major \\
\hline Nitrogen (all forms) & $0.07-16$ & & Major \\
\hline Nitrate & $0.01-12$ & & \\
\hline Oil and grease & $0.001-110$ & & Minor \\
\hline $\mathrm{PAH}$ & $2.4 \mathrm{E}-6-0.013$ & & No \\
\hline $\mathrm{PH}$ & $4.5-8.7$ & & Minor \\
\hline Petroleum hydrocarbons & $0.64-19.71$ & & \\
\hline Phenol & $0.003-0.01$ & & Minor \\
\hline Phosphorus (total) & $0.01-7.3$ & $0.015-0.82$ & Minor \\
\hline Sulfate & $0.06-1252$ & & \\
\hline TSS & $1-36200$ & $4-1223$ & Major \\
\hline Zinc & $0.00007-22$ & $0.017-0.58$ & Major \\
\hline
\end{tabular}




\section{Chapter 3: Regulation Policies}

\section{The Clean Water Act}

The Clean Water Act was first legislated under the name of the Federal Water Pollution Control Act in 1948. In 1972 the act was vastly expanded and was ultimately the Clean Water Act (CWA). CWA creates some basic guidelines and standards for regulating discharges of pollutants into surface water bodies in the United States. Any water which is legally navigable must follow the Clean Water Act. The Supreme Court has stated that the term "Waters of the United States" includes "only those relatively permanent, standing or continuously flowing bodies of water "forming geographic features" that are described in ordinary parlance as "streams, ... oceans, rivers, and lakes."

Under the CWA, the EPA has put some standards on the quality of the surface waters as well as some standards on the wastewater pollution from industry. Under EPA's National Pollutant Discharge Elimination System (NPDES), an NPDES permit is required by the CWA and regulates pollution point sources that discharge into water bodies. NPDES also states that those who discharge stormwater into water bodies should have a permit. Since the authorization of the NPDES permit there has been significant improvement in water quality.

The city of Portland has established a "Phase I National Pollution Discharge Elimination System" (NPDES) under the CWA. The Oregon Department of 
Environmental Quality (DEQ) issued the first permit for the City of Portland in 1995, renewed it in 2004 and modified it again in 2005. The co-permittees of the City of Portland, and the Port of Portland submitted for the third renewal in 2008. DEQ issued the final version on January 312011 . This permit will be effective for 5 years, until January 30, 2016.

The Storm Water Management Manual (SWMM) contains the city of Portland's stormwater management requirements. A crucial part of the SWMM is Appendix B, the "Vendor Submission Guidance for Evaluating Storm Water Treatment Technology". Appendix B include the rules, regulations and requirements needed for stormwater pollution reduction, and any vendor who intends to present their devices to City of Portland needs to demonstrate that their device passes the rules in Appendix B. Right now the City of Portland has placed a priority on removing the Total suspended solids.

One reason for concentrating on total suspended solids (TSS) is because not only TSS is considered a pollutant, but also other pollutants are associated with TSS, such as agricultural chemicals, metals, nutrients (phosphorus and nitrogen), petroleum hydrocarbons, oil and grease, and floatables (debris and litter). Thus, TSS removal will result in treating the pollutants that are associated with TSS (Bruland et al., 1974; USEPA, 1984). Another reason is because solids are somewhat easy and inexpensive to quantify. (Clark and Pitt, 2008) suggest that treating suspended solids is "considered the easiest parameter to simulate, since there are no 
interfering reactions to simulate and no associations between dissolved and particulate pollutants to investigate. “

Appendix B, mentions the USGS policy about the collection and use of TSS data in determining the suspended sediment load in stormwater runoff. The city has reviewed the USGS “Comparability of Suspended-Sediment Concentration and Total Suspended Solids Data" in August of 2000 and therefore has decided to simplify Portland's sampling specifications and use the Total Suspended Solids Analytical Method, as described by the American Public Health Association, American Water Works Association, and Water Pollution Control Federation to analyze test samples. It is believed that the Suspended-Sediment Concentration Analytical Method, however, measures all sediment and the mass of the entire water-sediment mixture.

A parallel system for stormwater quality management is currently in use in the state of Washington. The land cover and climate in western Washington are similar to Portland. However, the specific rules for the treatment of stormwater runoff for the State of Washington are somewhat different than those of Portland. Washington's program, known as TAPE (Technology Assessment Protocol-Ecology) (Howie, 2011; Hoppin, 2008) provides the regulations and rules for emerging stormwater technologies. TAPE contains performance goals and design criteria for emerging stormwater treatment technology. The similarities and distinctions between the Portland and the TAPE design criteria are discussed in depth in the next chapter. 


\section{Stormwater Treatment Technologies}

Stormwater treatment technologies depend on the chemical and biological properties of the stormwater, as well various engineering methods available. As the knowledge about waste water and its properties has increased, so have the technologies we use for treating water. This increase of knowledge has led us into various sophisticated technologies which not only are able to treat the water up to the needed standards, but are also cost effective. Stormwater treatment could be categorized into public domain technologies and pre-engineered technologies. Some public domain technologies are grass swales, wetland swales, filter strips, wet vaults, oil/grit separators, sand filters, wet ponds, oil/water separators, peat/sand filters, peat filters, iron-amended sand filters, and constructed wetlands. For preengineered technologies Stormfilter from ConTech Corp. is a good example, since it has been approved in Portland. A complete list of stormwater treatment technologies accepted by Portland is presented in the appendix. (Jurries, 2003; Carleton et al., 2001; Passeport et al., 2009) 


\section{Chapter 4: Portland Stormwater Management System}

\section{Stormwater Treatment in Portland}

Portland has a federal stormwater permit which requires Portland to reduce stormwater pollution. (http://www.portlandonline.com/bes/index.cfm?c=31892). The Oregon Department of Environmental Quality (DEQ) issued another permit named Water Pollution Control Facilities (WPCF). The WPCF is for the protection of the ground water and is about prevention, minimization and control of pollutants of stormwater just before it infiltrates. These two permits were set to be managed by the Bureau of the Environmental Services (BES) in June 1995 and adopted by the city council as an administrative rule. [Stormwater management manual(2008)] The permit area for Portland is for the municipal separate storm sewer system (MS4) which covers an area of roughly 15,627 acres. This area does not cover stormwater that flows to sumps and combined sewers, natural streams and direct stormwater discharges from private property into natural stream systems which do not enter the MS4. Also not included are the areas with no stormwater structures and areas which have their own permits.

The resulting stormwater management plan(2008) has two components: best management practices (BMPs) and measurable goals. BMPs include approaches that prevent pollution, such as education programs, and treatment facilities that remove the pollutions such as grassy swales, wetland detention systems, and mechanical devices such as oil/water separators. (City of Portland Stormwater 
Management Plan, 2011) a summary of the BMPs by the City of Portland Stormwater Management Plan is provided in the appendix(Passeport et al., 2009).

It is important to note that Portland requires all new development projects or redevelopments to have a stormwater facility; depending on the land use reviews, zoning, site development and building permits they will receive a unique set of permits. Any development or redevelopment project that is in either one of the following categories is subject to these permits [Portland Stormwater Management Manual, (2008)] :

1. Any property which plans to have new offsite discharges or new connections to the public system for the impervious area draining into the discharge point.

2. Projects that develop or redevelop over $500 \mathrm{ft}^{2}$ of impervious surface.

These properties could be public or private; if the discharge is from the private property, it should be managed on the private property and vice versa.

Portland finances stormwater management services by collecting public utility fees on developed property, and system development charges (SDCs) on new development. (http://www.portlandonline.com , Stormwater Management in Portland(2008)) 


\section{Stormwater Management Requirements of the City of Portland}

Any vendor who intends to use their technology in Portland needs to follow the guidelines required by Portland. These guidelines cover both the accepted storms that are to be treated and the amount of pollution and efficiency that should be treated. Portland's stormwater management system requires the pollution reduction facilities to present at least fifteen storm events each having some sub samples. The events must have the following characteristics:

- The events should be from at least three different sites with a minimum of five events with at least two different land uses for a total of 15 events.

- The minimum storm depth, for the events is 0.12 inches since any depth lower typically will not produce sufficient runoff.

- The minimum storm intensity is $0.02 \frac{i n}{h r}$.

- The maximum average rainfall intensity shall be $0.1 \frac{\mathrm{in}}{\mathrm{hr}}$.

- There should be at least 6 hours without any rain before the start of our event and at least 6 hours without rain after the end of our event.

- The rain event should produce at least 6 hours of runoff.

- The facility must be able to treat at least $90 \%$ of the average annual runoff. 
- The samples should be between $10 \%$ to $100 \%$ of the design facility flow rate, for offline facilities and between $10 \%$ to $125 \%$ of the design facility flow rate, for the on-line facilities.

- The events should be sampled throughout the year so that no more than $70 \%$ of the samples be in either the wet or dry seasons.

The sample data collection sheet for the vendors is in the appendix. The vendors must also be able to treat the pollutions as listed:

\section{Total Suspended Solids}

The treatment goal for stormwater pollution is 70\% TSS removal from $90 \%$ of the average annual runoff. In order to do this, BES uses a "line of comparative performance", or, "Portland's standard performance line" which is more completely described in the next sections. For influent concentrations lower than $70 \mathrm{mg} / \mathrm{l}$, the facility must achieve an effluent of $20 \mathrm{mg} / \mathrm{l}$ or less. In TSS treatment, particle size distribution analysis is also important since it shows the facilities ability in removing all sizes of the sediments. Particle size distributions are shown in Table 3.

Table 3: Particle size distribution removal requirements (Portland's Stormwater Management Manual(2008))

\begin{tabular}{|c|c|}
\hline $\begin{array}{c}\text { Particle } \\
\text { Diameter }\end{array}$ & $\begin{array}{c}\% \text { less than } \\
\text { (Weight) }\end{array}$ \\
\hline$<1000$ micron & $100 \%$ \\
\hline$<707$ micron & 95 to $100 \%$ \\
\hline$<595$ micron & 90 to $95 \%$ \\
\hline$<420$ micron & 85 to $90 \%$ \\
\hline$<297$ micron & 80 to $85 \%$ \\
\hline$<177$ micron & 75 to $80 \%$ \\
\hline \multicolumn{2}{|c}{} \\
\hline
\end{tabular}




\begin{tabular}{|l|l|}
\hline$<88$ micron & 50 to $75 \%$ \\
\hline$<44$ micron & 25 to $50 \%$ \\
\hline$<16$ micron & 0 to $25 \%$ \\
\hline$<8$ micron & $0 \%$ \\
\hline
\end{tabular}

In order to calculate the efficiency of the devices, four different methods have been introduced. Some of these methods give the efficiency for individual storms and some give the average efficiency. These four methods are in the appendix.

\section{TMDL Enhanced Performance Goal}

TMDL, or total maximum daily load, is the maximum amount of pollution that a watershed discharges to the receiving water that is allowed by the standards. Some watersheds have a certain TMDL rule. The TMDLs apply specific pollution control requirements to designated pollutants of concern (Portland's Stormwater Management Manual(2008)). In order to keep certain watershed pollutions within its TMDL requirements, any development is required to use some kind of treatment facility to keep the specific pollutions to the required levels. "To be considered for use as a stand-alone facility in a TMDL watershed, a manufactured technology must demonstrate removal efficiencies for specific pollutants of concern, as well as TSS." (Portland's Stormwater Management Manual(2008)).

\section{Oil and Grease Removal}

Some of the sites, like parking lots, require additional treatment for oil and grease due to their high risk and high usage. Appendix B presently requires only the 
pretreatment of oil and grease at effluent levels of $10 \mathrm{ppm}\left(\frac{\mathrm{mg}}{\mathrm{L}}\right)$ for influents higher than 50 ppm $\left(\frac{m g}{L}\right)$.

\section{Maintenance}

"Manufactured technologies claiming effectiveness for the listed pollutants must demonstrate that the above treatment performance goals will be generally achieved. Facilities shall be designed to perform without maintenance for one full year." (Portland's Stormwater Management Manual(2008)). If a facility is not able to keep up with the maintenance requirements, then that facility will not be accepted to be used in Portland.

\section{Data Submission}

1. The stormwater treatment device vendors need to submit at least 30 tests and half of those tests must be from field studies with real or artificial storm data. These storms must meet the following criteria:

2. At least five storm events from three different sites must be submitted (total of 15 events). At least two different land uses must be considered choosing the sites. The land uses must be either one of medium density residential, retail commercial, non-retail commercial, or industrial. No more than $70 \%$ of the samples should be from the wet or dry seasons.

3. Minimum total storm depth shall be 0.12 inches; at least $50 \%$ of the storms should exceed 0.42 inches and $10 \%$ or more should exceed 0.83 inches. A 
storm should produce at least six hours of runoff with at least six hours of no recorded storm before and after the event. Considering the six hours of rainfall and the storm depth, minimum average rainfall intensity shall be 0.02

$\frac{\text { inch }}{h r}\left(\frac{0.12 \text { inch depth }}{6 \text { hours }}\right)$. At least $50 \%$ of the storms should exceed $0.03 \frac{\text { inch }}{h r}$ and $10 \%$ or more should exceed $0.05 \frac{\mathrm{inch}}{\mathrm{hr}}$. maximum average intensity is $0.1 \frac{\mathrm{inch}}{\mathrm{hr}}$

\section{Technology Assessment Protocol- Ecology (TAPE)}

TAPE is a program administrated by the state of Washington Department of Ecology, with assistance from the Washington Stormwater Center [wastormwatercenter.org] which provides regulatory certification process for emerging stormwater treatment technologies and design criteria and performance goals for stormwater treatment facilities. TAPE provides the stormwater management manuals for both western Washington (SWMMWW) and eastern Washington (SWMMEW).[Guidance for evaluating emerging stormwater treatment technologies-TAPE](Howie, 2011; Hoppin, 2008)

\section{Comparing the City of Portland's Stormwater Management System and TAPE}

Even though the climatology and geographic land cover of the city of Portland and the western Washington are very similar, the standards set by Appendix B and TAPE are not the same. Because of the difference in the requirements accepted by them, it is not possible to accept vendor's devices which were accepted by TAPE for the City of Portland without any further investigations. 
In order to clarify this issue, the first step is to find the differences between TAPE(Howie, 2011; Hoppin, 2008) and SWMM.

A comparison of the main rules passed in Appendix B and TAPE (Hoppin, 2008)are found in Table 4.

Table 4: Stormwater treatment requirements in the city of Portland versus the state of Washington

\begin{tabular}{|c|c|}
\hline City of Portland & State of Washington \\
\hline $\begin{array}{l}90 \% \text { of average annual runoff should be } \\
\text { treated }\end{array}$ & $\begin{array}{l}91 \% \text { of the runoff volume should } \\
\text { be treated }\end{array}$ \\
\hline $\begin{array}{l}\text { From the } 90 \% \text { of average annual runoff } \\
\text { which is treated, there should be } 70 \% \\
\text { TSS removal runoff }\end{array}$ & $\begin{array}{l}\text { From that } 91 \% \text { of the average } \\
\text { annual runoff, there should be } \\
80 \% \text { removal of TSS for influent } \\
\text { concentrations between } 100 \text { to } \\
200 \frac{m g}{L} \text {, for higher influent } \\
\text { concentrations there should be } \\
\text { higher removal efficiency for } \\
\text { influent less than } 100 \frac{\mathrm{mg}}{\mathrm{L}} \text { effluent } \\
\text { should be } 20 \frac{\mathrm{mg}}{\mathrm{L}}\end{array}$ \\
\hline 5 storm events from 3 different sites & Minimum number of events is \\
\hline
\end{tabular}




\begin{tabular}{l|l}
\hline must be submitted from a total of 15 & between 12 to 35 events \\
events & \\
\hline The samples should be from 3 different & 1 field site \\
sites with 2 different land uses & There is no requirement for \\
\hline No more than $70 \%$ of the samples may & seasonality in the TAPE (1011) \\
be in the wet or dry seasons & version \\
\hline The minimum storm depth is 0.12 & The minimum storm depth is 0.15 \\
inches. At least $50 \%$ of the sampled & inches. \\
storms should exceed 0.42 inches at & \\
least $10 \%$ should exceed 0.83 inches & \\
\hline Minimum runoff duration should be 6 & Minimum runoff duration should \\
rain before the start of our event & be 1 hours \\
\hline hours & inches of depth before the start of \\
\hline
\end{tabular}




\begin{tabular}{|c|c|}
\hline & $\begin{array}{l}\text { inches of depth after the end of } \\
\text { our event }\end{array}$ \\
\hline $\begin{array}{l}\text { Minimum storm intensity is } 0.02 \frac{i n}{h r} \text { with } \\
50 \% \text { exceeding } 0.03 \frac{i n}{h r} \text { and } 10 \% \text { to } \\
\text { exceed } 0.05 \frac{i n}{h r}\end{array}$ & $\begin{array}{l}\text { Must sample different ranges of } \\
\text { intensities }\end{array}$ \\
\hline $\begin{array}{l}\text { The samples should be between } 10 \% \text { to } \\
100 \% \text { of the design facility flow rate for } \\
\text { the offline facilities, and between } 10 \% \text { to } \\
125 \% \text { of the design facility flow rate for } \\
\text { the on-line facilities. }\end{array}$ & $\begin{array}{l}\text { The samples should be between } \\
50 \% \text { to } 125 \% \text { of the design facility } \\
\text { flow rate }\end{array}$ \\
\hline $\begin{array}{l}\text { final composite sample should have at } \\
\text { least } 10 \text { influent and } 10 \text { effluent } \\
\text { subsamples }\end{array}$ & $\begin{array}{l}\text { final composite sample should } \\
\text { have at least } 7 \text { to } 10 \text { subsamples }\end{array}$ \\
\hline Sample coverage should be $75 \%$ & $\begin{array}{l}\text { Sample coverage should be } 75 \% \text { of } \\
\text { first } 24 \text { hours }\end{array}$ \\
\hline $\begin{array}{l}\text { Maximum average rainfall intensity is } \\
0.1 \frac{i n}{h r} \text {. }\end{array}$ & \\
\hline
\end{tabular}


According to table 4, in some items, the state of Washington has stricter rules, in those cases, if the device is accepted by the state of Washington for that property; it will be accepted by Portland as well. In some other parts, the properties of TAPE are different from Portland's Appendix B (SWMM). A goal of this project was to identify practical congruencies between seemingly different state requirements, such that Portland BES could apply selected Washington data for the technology approval process. 


\section{Challenges in the Current Stormwater Treatment Policies of Portland}

Runoff is produced for various storms depending on many characteristics of a site including slope, surface texture and impermeability, and existing moisture content. The minimum storm depth for the purpose of sampling to determine effectiveness of stormwater treatment facilities is set at 0.12 inch because it is associated with a storm that would begin to produce runoff and be capable of moving solids.

The minimum duration of runoff is specified to be 6 hours by the City of Portland. If the duration is reduced, it would make it easier for someone trying to test stormwater treatment facilities, as they wouldn't have as many wasted efforts, since minimizing this restriction will result in a larger number of acceptable events. A long runoff period is nice in that it allows many samples to be taken throughout the duration of flow through the facility, so theoretically one could learn more about solids transport associated with different intensities through the storm and facility performance for different runoff pollutant concentrations.

The minimum average rainfall intensity of 0.02 inches per hour set by Portland is also associated with a storm's ability to produce runoff and transport solids. The maximum average rainfall intensity of 0.1 inches per hour is somewhat important in that a manufacturer of a treatment device is not required to demonstrate high efficiency in TSS removal solely on very intense storms that move a high percentage of coarse solids through the device. 
In chapter 5 we try to address other criteria that seem to be too restrict for stormwater treatment sampling.

In this chapter and chapter 5 , the main focus is on current requirements, especially the ones that might be more of concern due to their restrictions. First the data worked with will be introduced. Figure 1 is a map of Portland with all the rain gauges currently working and all the gauges which have discontinued working. Not all the gauges have data for all years in the 31 years study period, since some of the gauges are newer and some are older and no longer in use.

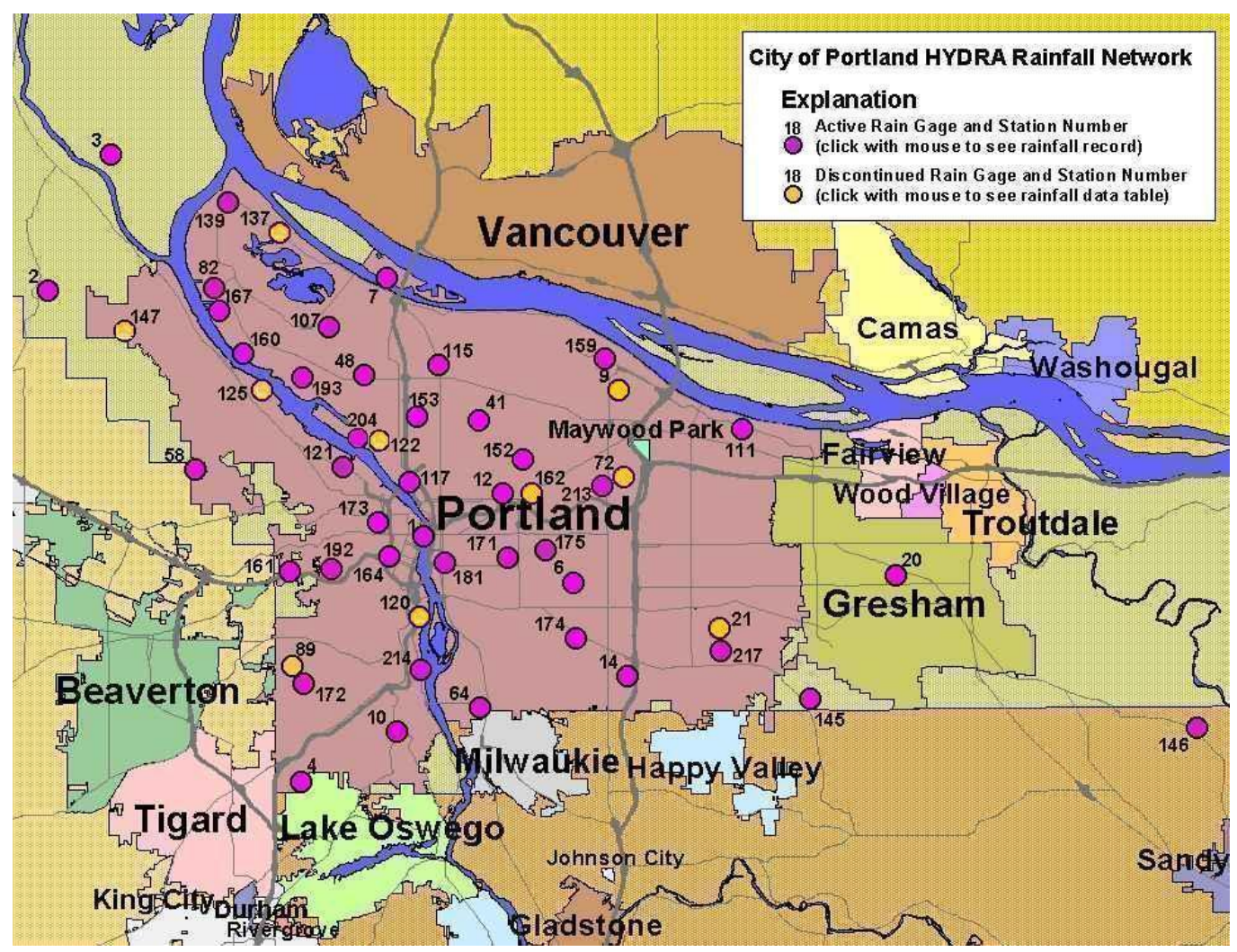

Figure 1: Map of Portland, Oregon with all the available gauges

This map can be obtained from 
http://or.water.usgs.gov/non-usgs/bes/raingauge info/clickmap.html

There are a total of 66 gauges, spread throughout Portland. The data are from 1980 to 2011. A list of all gauges can be found in Appendix. Rainfall data were collected for each gauge for the duration over which the gauge worked during that 31 years. These data included the gauge properties, and the hourly rain depth. These precipitation data were fitted by all the required rules set by Portland in order to show which events would be accepted as an event that could be used in an approved sampling program. In any case which a rule might have been changed, it has been mentioned.

\section{Seasonality}

One of the main differences between TAPE(Hoppin, 2008) and SWMM (Appendix B), is seasonality. In SWMM, it is stated that "No more than $70 \%$ of the samples may be in the wet or dry seasons" while TAPE(Hoppin, 2008) has no specific rule for seasonality. It could be argued that the word "may" used in the statement is not a "must" but merely it is just a suggestion. However, the reasonable inference that at least $30 \%$ of usable storm sampling events must be in the dry season is problematic since the rain in Portland's dry season mostly drizzles and might not meet duration and intensity standards.

The following information is gathered from 31 years of precipitation data (from year 1980 to 2011) in the City of Portland. The data were extracted from 66 
gauges throughout the city. It was decide to use most of the trusted gauges, because the climate in Portland changes in very small distances. It is also important to note that not all gauges have information for all the 31 years. Some of the gauges are newer and have no information from older years, some gauges have stopped working, so they do not have any information for recent years, and some gauges have data somewhere in the middle. But all the gauges reported were functioning with dependable data.

According to Appendix B, no more than $70 \%$ of the real storm may be in the wet or dry season. Appendix B considers months may through September as dry season and months October through April as wet season. Figure 2 shows the average monthly rainfall intensity graph $\left(\frac{i n}{d a y}\right)$. Each line in the graph indicate the average rainfall intensity for a certain year. Inspection of figure 2 reveals that the rainfall intensity during the dry season in the City of Portland is very low, frequently $<0.2 \frac{\text { in }}{d a y}$. 


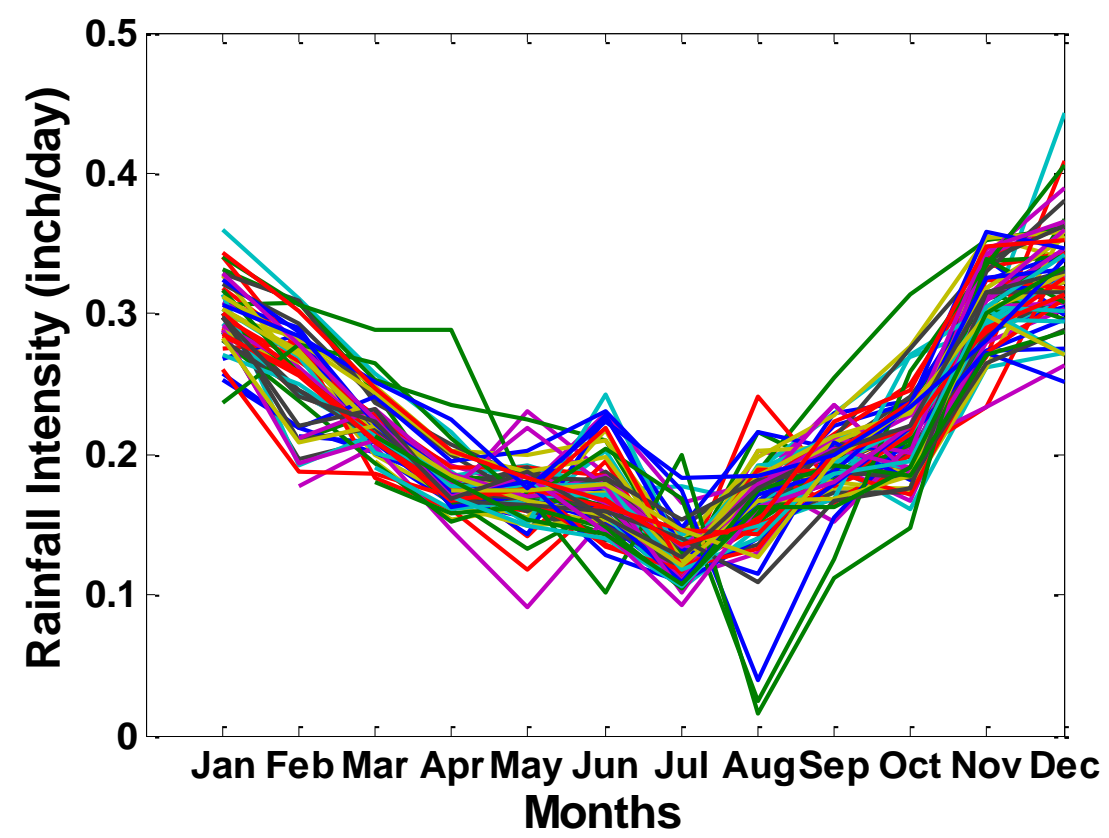

Figure 2: Average daily precipitation intensity for all gauges for each month, 1980-2011. 


\section{Chapter 5: Results}

\section{Statistical Analysis of Portland Rainfall Events for Sampling Suitability}

After applying the required rules to the rainfall in both dry and wet seasons, the number of accepted events in comparison with the number of available data reduced greatly. Due to climate of Portland, these restrictions were not a big problem during the wet season, since Portland gets enough rain at that period, the problems occur during the dry season when the rain is shorter, less frequent and more of drizzle especially that during the dry season there is less chance to have a rain event which lasts at least six hours, in order to produce six hours of runoff, and have no rain before and after that rainfall. The data presented in Figure 3 give an insight to the number of events accepted by the requirements of Portland throughout the year, by all the gauges. Each box plot shows the range of events happening in all the gauges that have information on that year, during the wet or dry season. It is important to note that there is no such thing as half an event.

The red line in each box plot is the median, with the upper bound as the $75 \%$ and the lower bound as $25 \%$, the points shown by a + are considered outliers.

Inspection of the box plot for the dry season shows that $75 \%$ of the gauges in the years 1980,1982, 1983, 1988, 1989, 1991, 1994, 1998, 2002, 2003, 2005, and 2006 have 0 or 1 events, while in the years 1981, 1987, 1992, 1996, and 2004 almost all the gauges had no accepted events. Also, the plot shows that 1993 and 
1995 where the only two years with a higher number of events in the dry season, with $75 \%$ of the gauges having 4 , or fewer event and $25 \%$ having 2 or fewer events.

Figure 4 is the box plot for the wet season. It shows that most of the gauges for most of the years have four or more events.

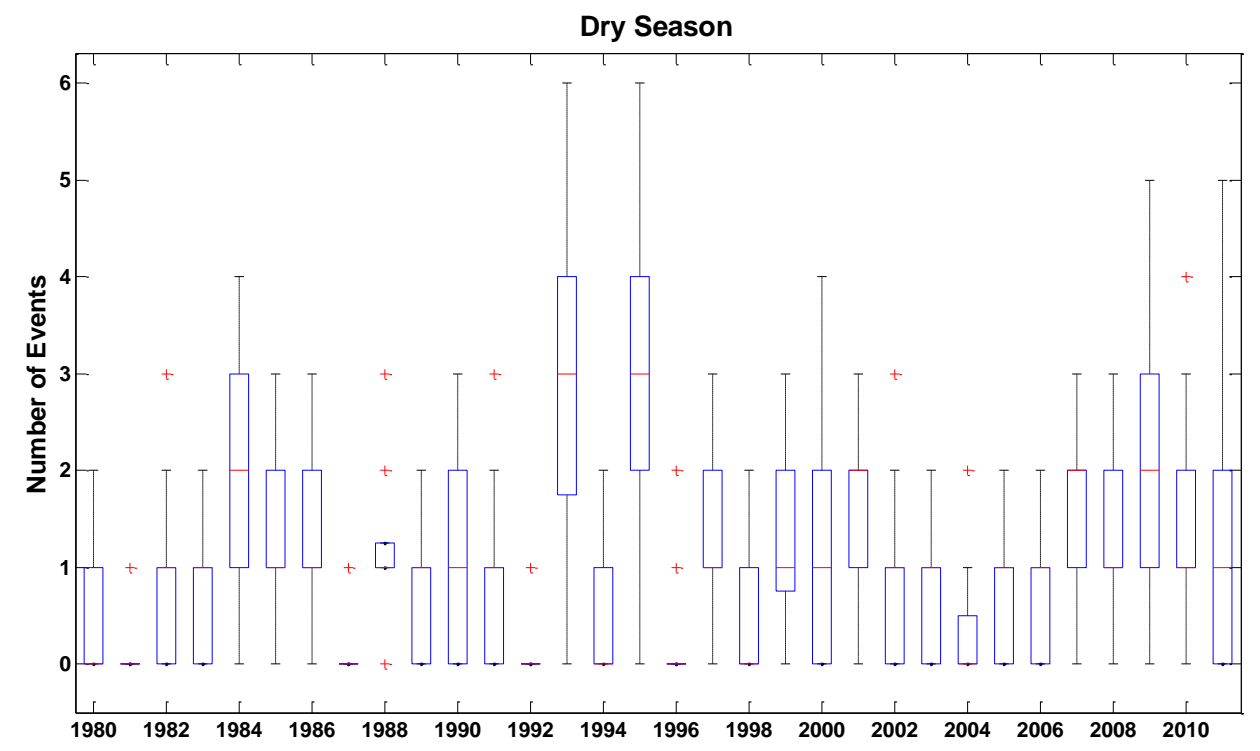

Figure 3: The total number of events for all gauges in each year during the dry season 


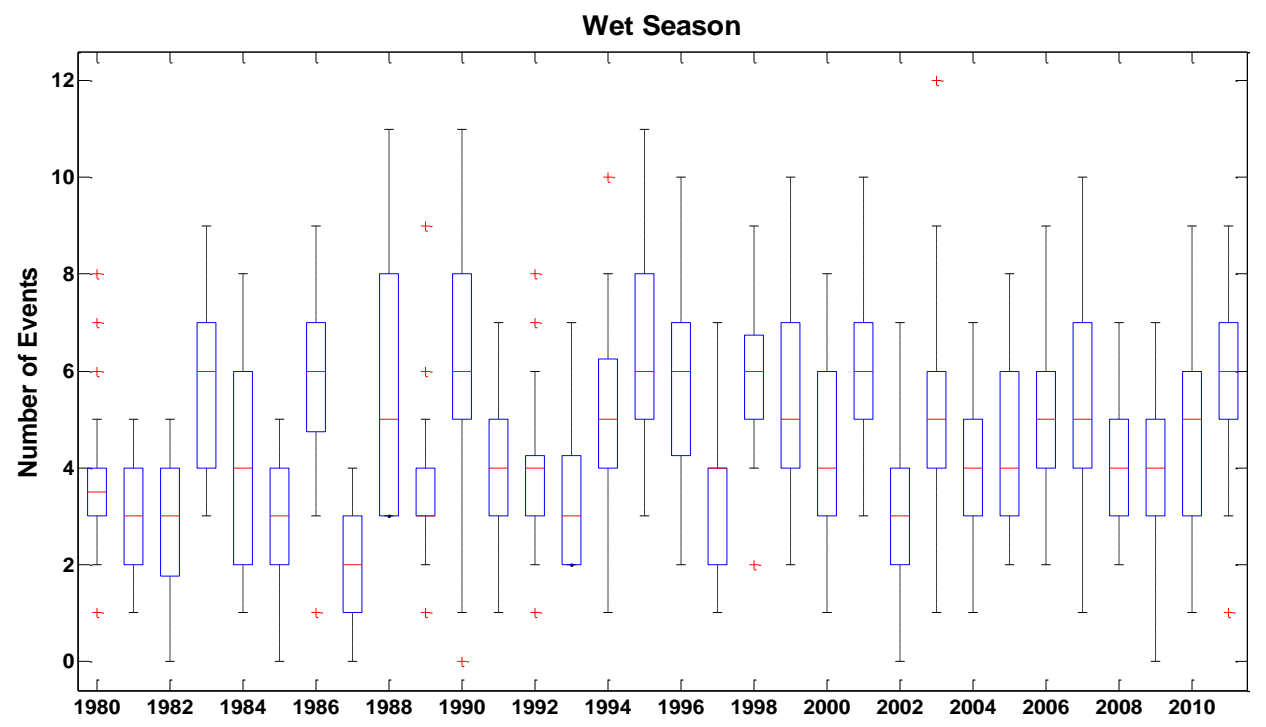

Figure 4: The total number of events for all gauges in each year during the wet season

In order to pass the $30 \%-70 \%$ rule, the vendor would need to actually lower the amount of the storm events to be processed. As an example, in a year in which there were only 10 storm events in the wet season and 1 storm event in the dry season, the 30\%-70\% rule means the vendor can only show 3 events, 2 wet and 1 dry, discarding 8 otherwise useful wet season events. By looking closely at the result, we can see that some years there were no rain events collected by any gauges in the dry season. In these cases the vendor has no choice but either to wait another year to get the samples, and therefore to postpone the project for a year, or not follow the rules required by Portland and get rejected by the city.

Figure 5 shows how many gauges have $\mathrm{x}$ number of storm events in the dry saeson, for all years of data. 


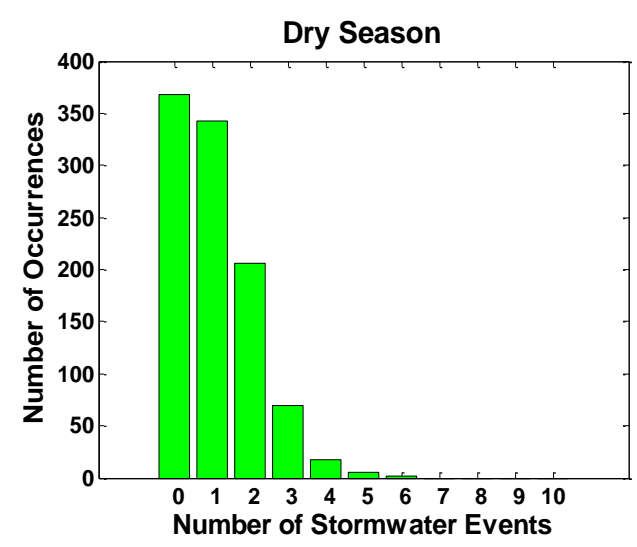

a. With no constraints

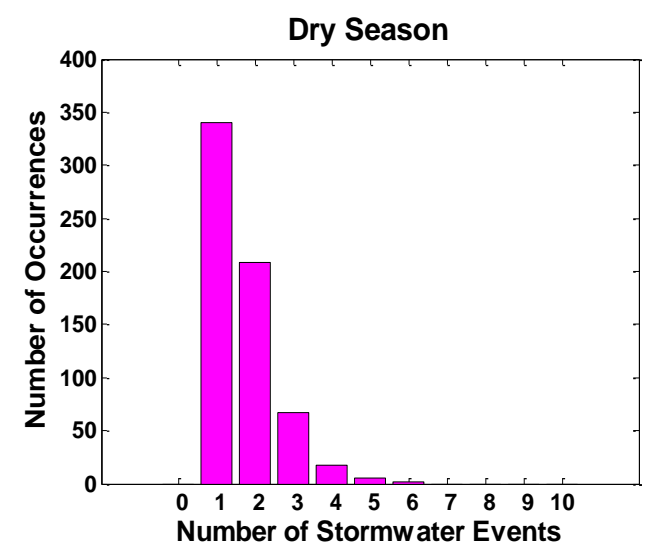

b. Considering the 30\%-70\% criterion

Figure 5: Histogram of the total number of events per gauge per year during the dry season

There are a number of gauges, maximum of 66 , which were working for a certain year (total of 31 years). If we consider each working gauge in each year a gauge-year couple (GYC), then according to Figure 5-a, more than 350 GYCs had 0 events during the dry season. More than 340 GYCs had 1 event during the dry season and about 200 GYCs had 2 events . the GYCs with 3 or more events were less than 100 all together. Figure 5-b, on the other hand shows the maximum number of events for each GYC, in order to meet the $30 \%-70 \%$ rule. As it shows, the main difference between figures 5 -a ans 5 -b is the 0 events column. Figure 5 -b is adjusted to the seasonality rule, so if a cretain gauge in a specific year has 0 acceptable events in the dry season, then the events for that gauge in that certain year in the wet seasonwill not be considered, since there has to be at least 1 event in both dry and wet seasons according to seasonality rules. 
Number of all the events in the dry season is 1072 events; after effecting the rule this number reduced to 1067 events.

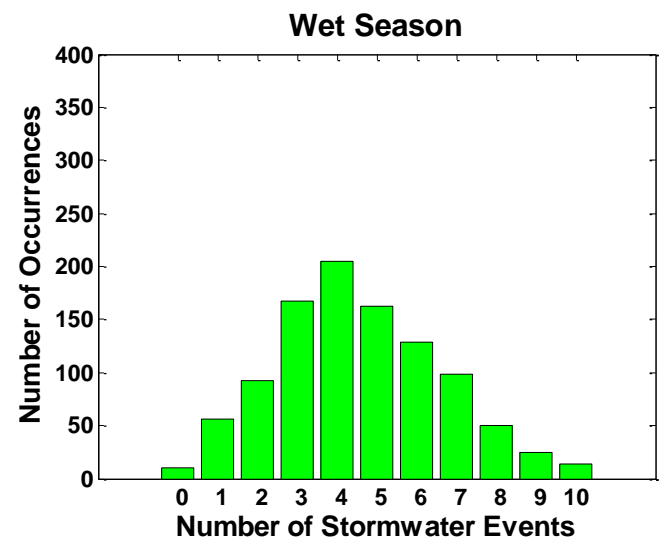

a. With no constraints

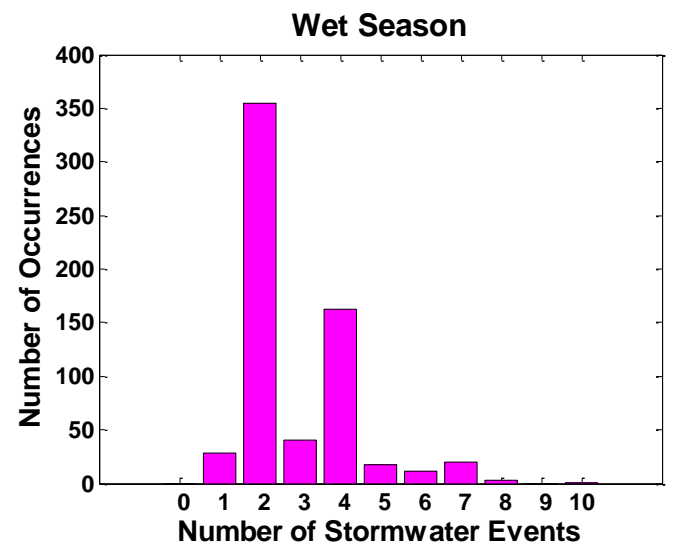

b. Considering the $30 \%-70 \%$ criterion

Figure 6: Histogram of the total number of events per gauge per year during the wet season

Figure 6 shows how many gauges have a given number of storm events in the wet saeson, for all years of data. The results of Figure 6-a can be approximated with a poisson distribution. According to this figure the most frequent number of events happening per gauge-year is four. The lowest frequent number of events per gaugeyear were zero and ten. Around 350 gauge-year couple have 2 events and about 150 gauge-year couple have 4 events in order to meet the 30\%-70\% SWMM seasonality rule. These two graphs are very different since the number of events had to be adjusted enormously in order to meet the $30 \%-70 \%$ rule, due to low number of dry season events in comparison to the wet season events. The number of all the events in the wet season is 4616 events. After effecting the rule this number reduced 
to just 1844 events. This means that we have lost 2772 events which is about $60 \%$ of the events which pass the required rules for accepltible rainfall, in order to obey the seasonality rule.

Table 5 : total number of accepted events with and without adjustment

\begin{tabular}{cccc}
\hline Season & Total Number & $\begin{array}{c}\text { Total Number adjusted } \\
\text { to seasonality criterion }\end{array}$ & Percent lost \\
\hline Dry season & 1072 & 1067 & $1 \%$ \\
Wet season & 4616 & 1844 & $60 \%$ \\
\hline
\end{tabular}

Figures 7-a and 7-b show a comparison the percentage of stormwater events per gauge-year with and without the seasonality (30\%-70\%) rule.

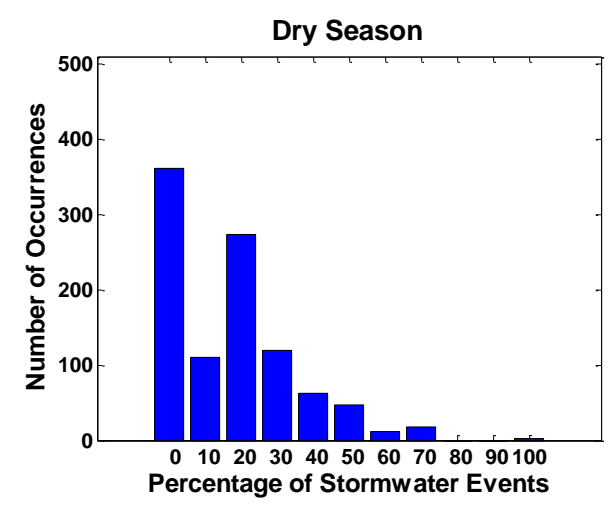

a. With no constraints

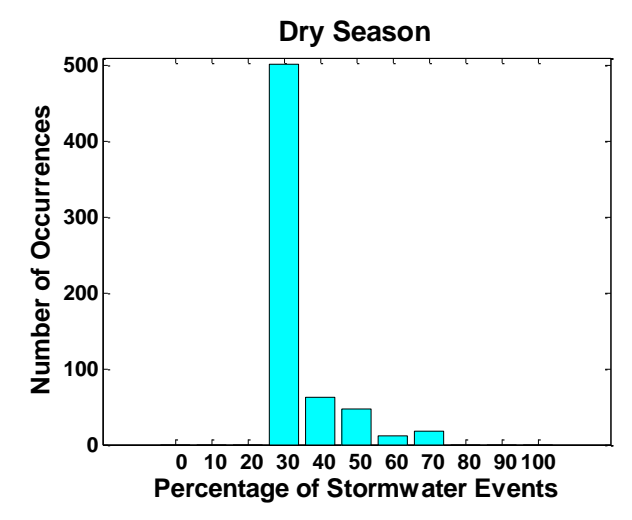

b. Considering the $30 \%-70 \%$ criterion

Figure 7: Histogram of the percentage of stormwater events per gauge per year during the dry season

Acording to figure $7-\mathrm{a}$, most og the GYCs have $0 \%, 10 \%$, or $20 \%$ of the events during the dry season, thus causing the lose of so many (60\%) events in the wet 
season after adjustin to the $30 \%-70 \%$ criterion. Figure 7-b is the adjusted histogram with a minimum of $30 \%$, and the maximum percentage is $70 \%$. This is also seen in the wet season in figure 8 .

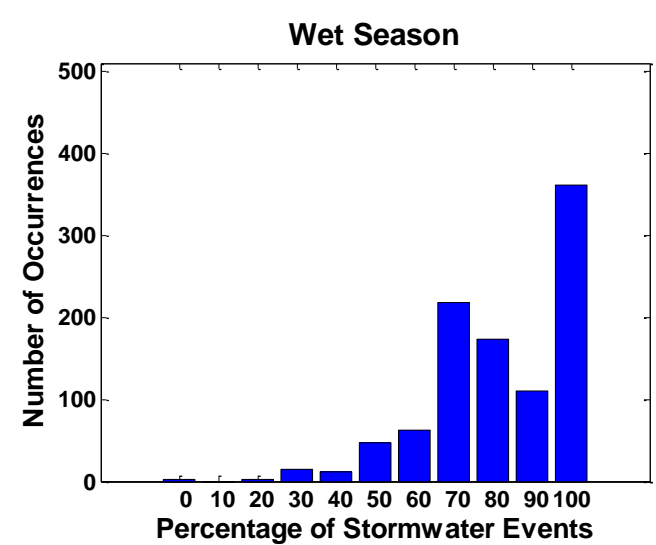

a. With no constraints

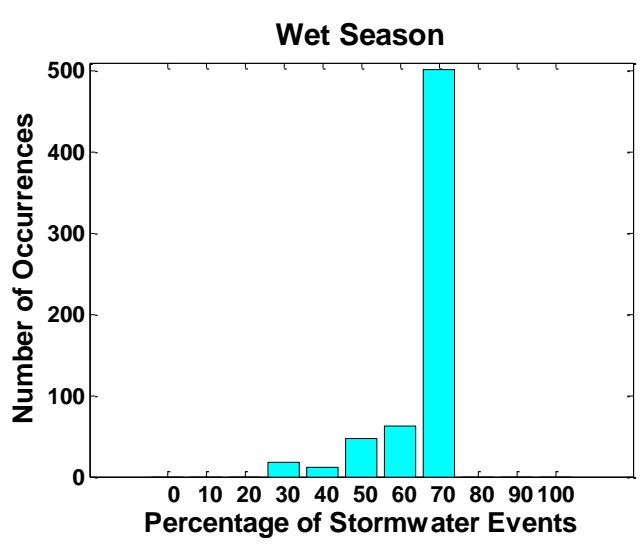

b. Considering the $30 \%-70 \%$ criterion

Figure 8: Histogram of the percentage of stormwater events per gauge per year during the wet season

And finally figure 9 shows the number of gauges which obey the 30\%-70\% rule, without any adjustment out of the number of all the gauges available for each certain year.

Figure 10 shows the number of gauges that obey the $30 \%-70 \%$ rule, with adjustment out of the number of all the gauges available for each certain year. This adjustment brings more gauges with events into rule compliance, but causes them to also lose some events as described before. 


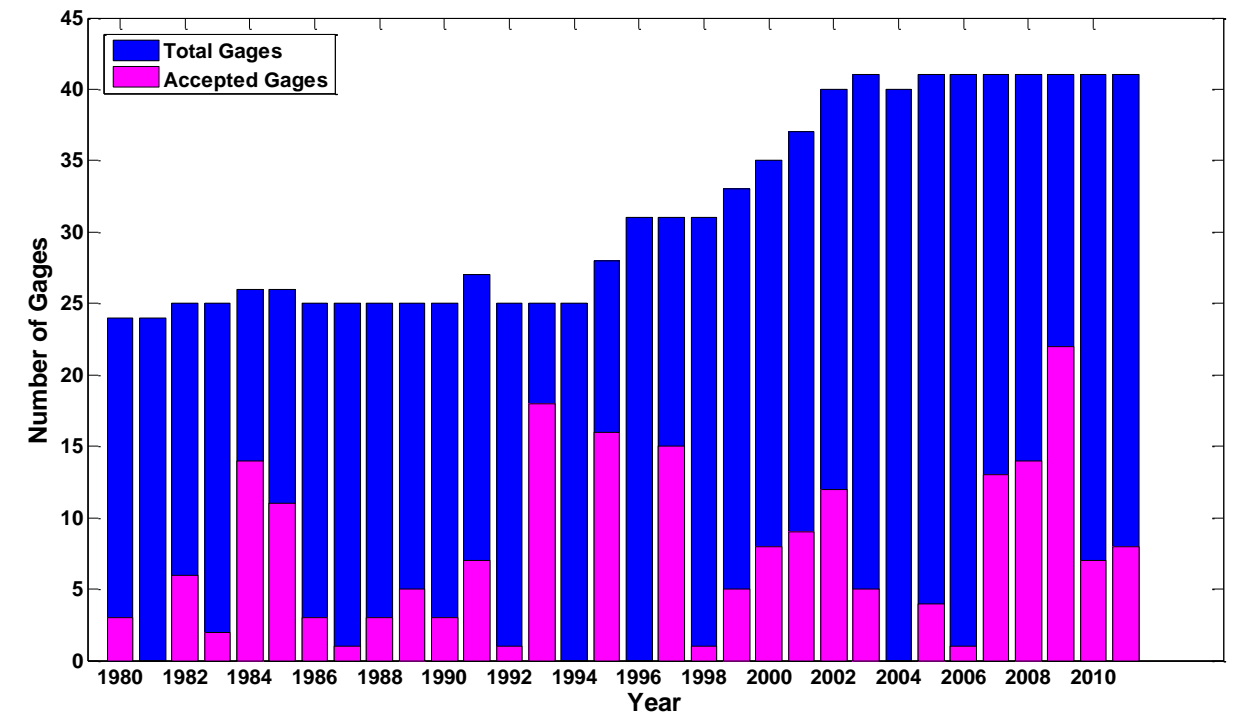

Figure 9: Number of gauges which follow the 30\%-70\% criterion compared to the total number of gauges at each year.

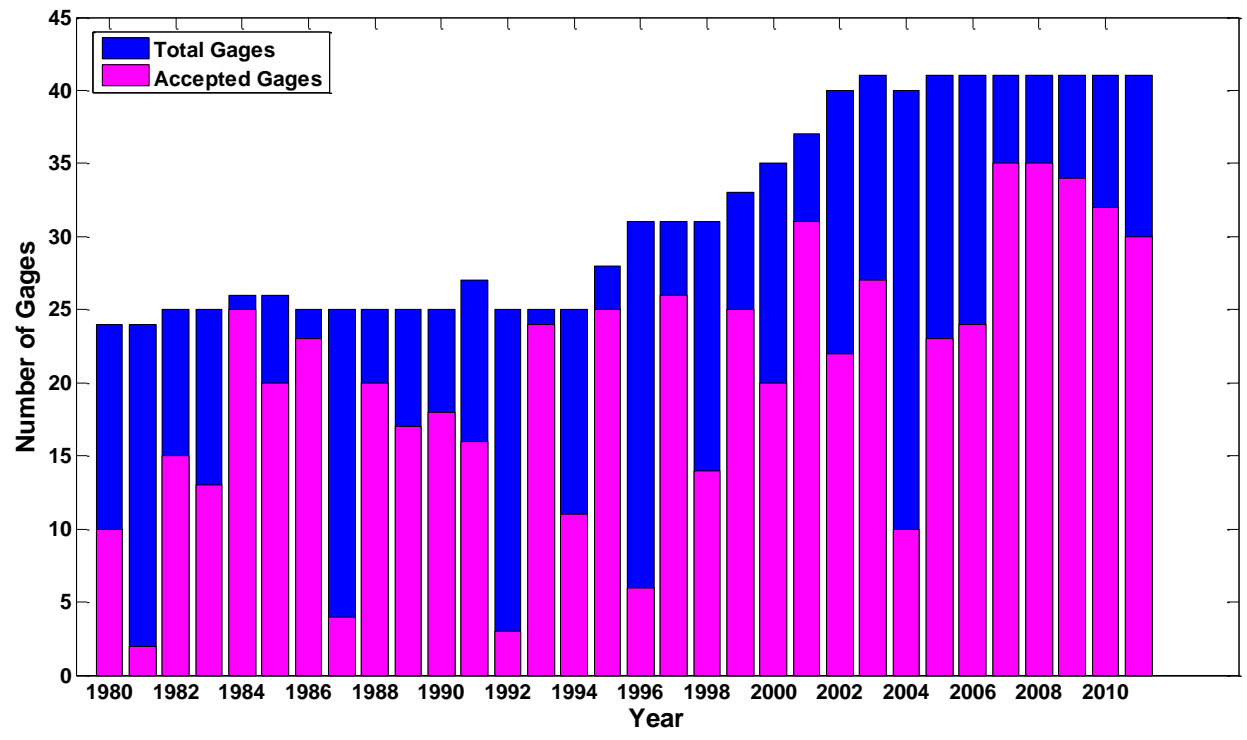

Figure 10: Number of gauges which follow the 30\%-70\% criterion compared to the total number of gauges at each year; when possible number of stormwater events were discarded to meet the $30 \%-70 \%$ criterion 


\section{Estimating the Number of Events Using the Average Daily Precipitation}

This part is mostly a guideline in order to predict the likely number of suitable events during the dry/wet seasons. This is good when a vendor is submitting their events; Since the number of the events a vendor hands out is directly dependent on the amount of daily precipitation, for example if that year there was many storm events, we are expecting the vendor the hand out more events and vice versa.

Based on all the regulations which filter the rainfall, it is not possible to count all the events and estimate the number as the number of rainfall a vendor should present since that number will be very higher than when the restrictions are applied.

To start, the first step was to create two matrices (Matrix 1 and Matrix 2). The rows were the gauges (all 66) and the columns were the years (from 1980 to 2011). In Matrix 1, the cells contain the average daily precipitation per year for each gauge and Matrix 2 cells contain the number of acceptable events per gauge per year. After sorting these two matrices, for each gauge, number of accepted events was plotted against the average precipitation for all the years that each gauge was valid (Figure 11). Please note that this whole process was first done for the events that accepted under the current Portland rules.

As shown in the graphs in Figure 11, there was mostly not a good trend and the relation between the average precipitation and number of available events was 
independent. The reason was having too many restrictions applied due to Appendix $\mathrm{B}$, since taking away each restriction will increase the correlation. These rules caused too many events not to be qualified for treatment testing. In order to see a good correlation, all the rules were kept intact except instead of no rain event for 6 hours before and after a rain event was reduced to no rain event for two hours. This process was done for both wet and dry season events individually. Figure 11, 12, 13 and Figure 14 represents plots for all the gauges which had data for both wet/dry seasons.

The plots suggest that in most gauges the number of events is dependent on the average daily precipitation. The correlation coefficient was calculated between the number of events and the average daily precipitation at each gauge in order to find the linear dependence between the two variables. Correlation coefficient was obtained from:

$$
\mathrm{r}=\frac{1}{n-1} \sum\left(\frac{x-\bar{x}}{s_{x}}\right)\left(\frac{y-\bar{y}}{s_{y}}\right) \text { (Equation 1) }
$$

Where $\mathrm{x}$ is the Average precipitation at each gauge and each year with the mean of $\bar{x}$ and standard deviation of $\mathrm{S}_{\mathrm{x}} \mathrm{y}$ is the number of events with the mean of $\bar{y}$ and standard deviation of $S_{y}$. The correlation coefficient ranges between -1 and 1 showing the highest negative or positive linear dependency. A correlation value of zero indicates no linear dependency between variables. 

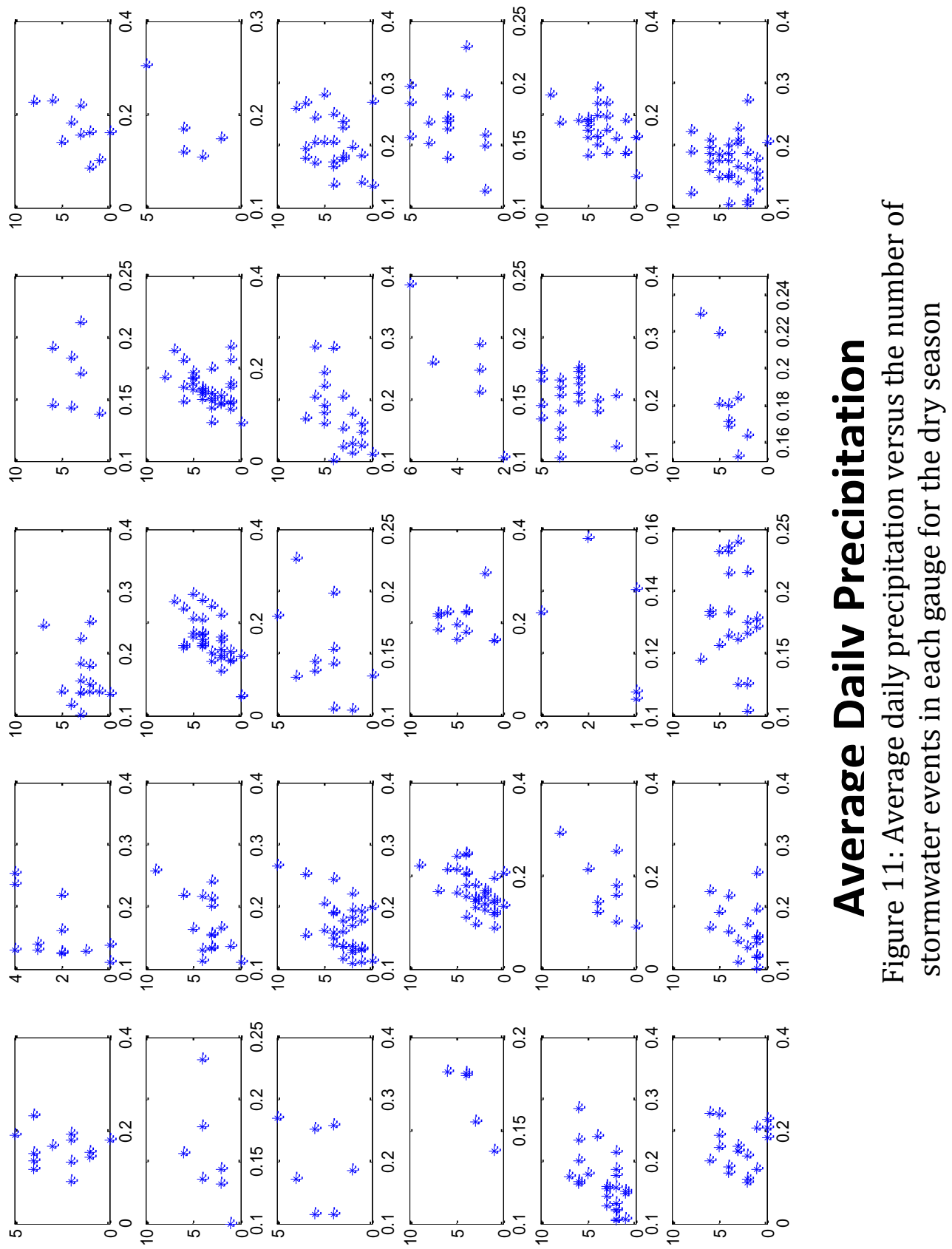

Number of Events 

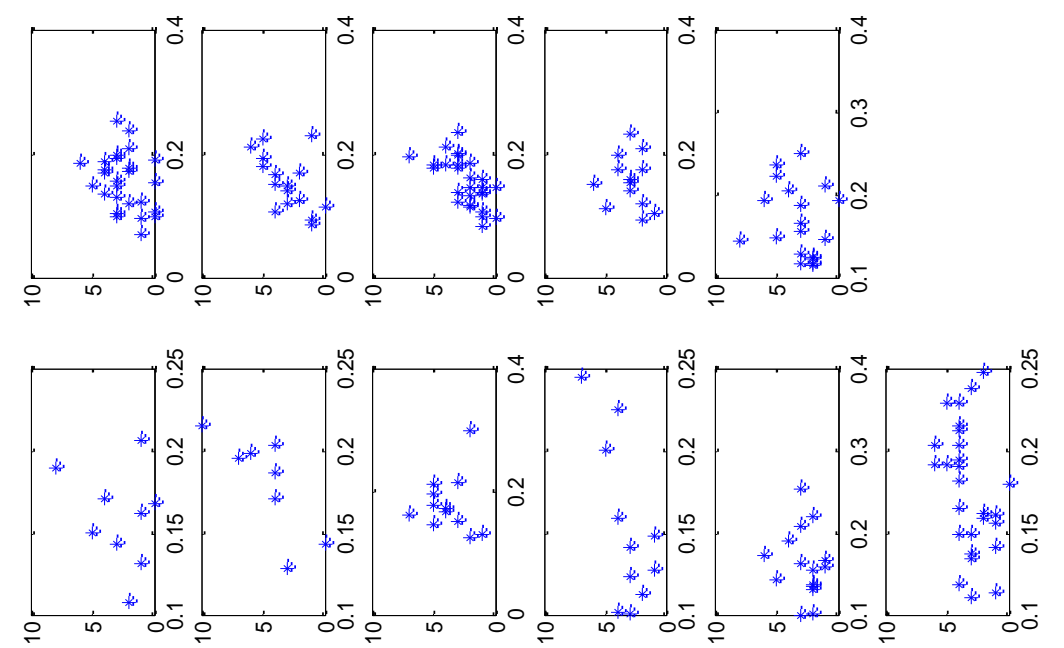

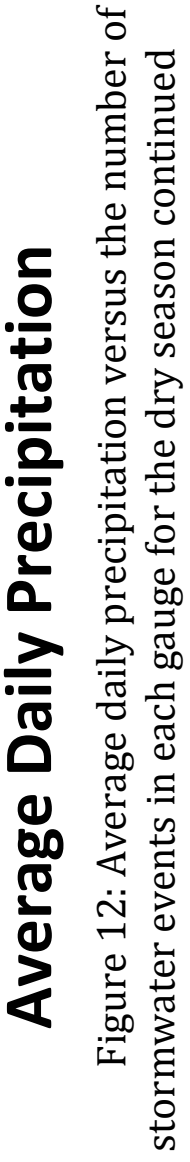

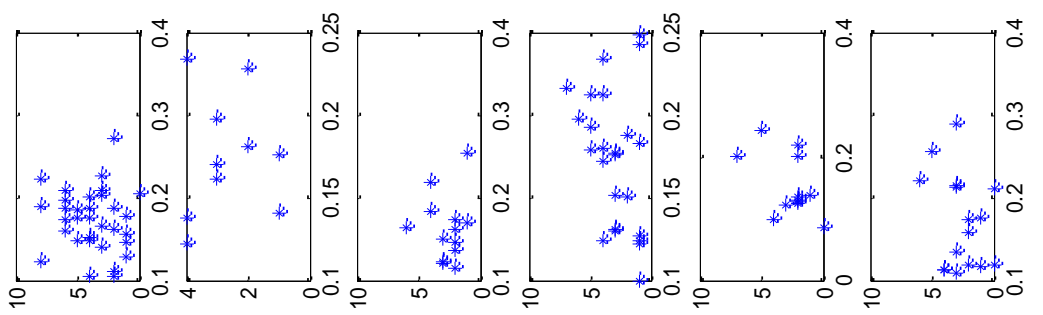

Number of Events 

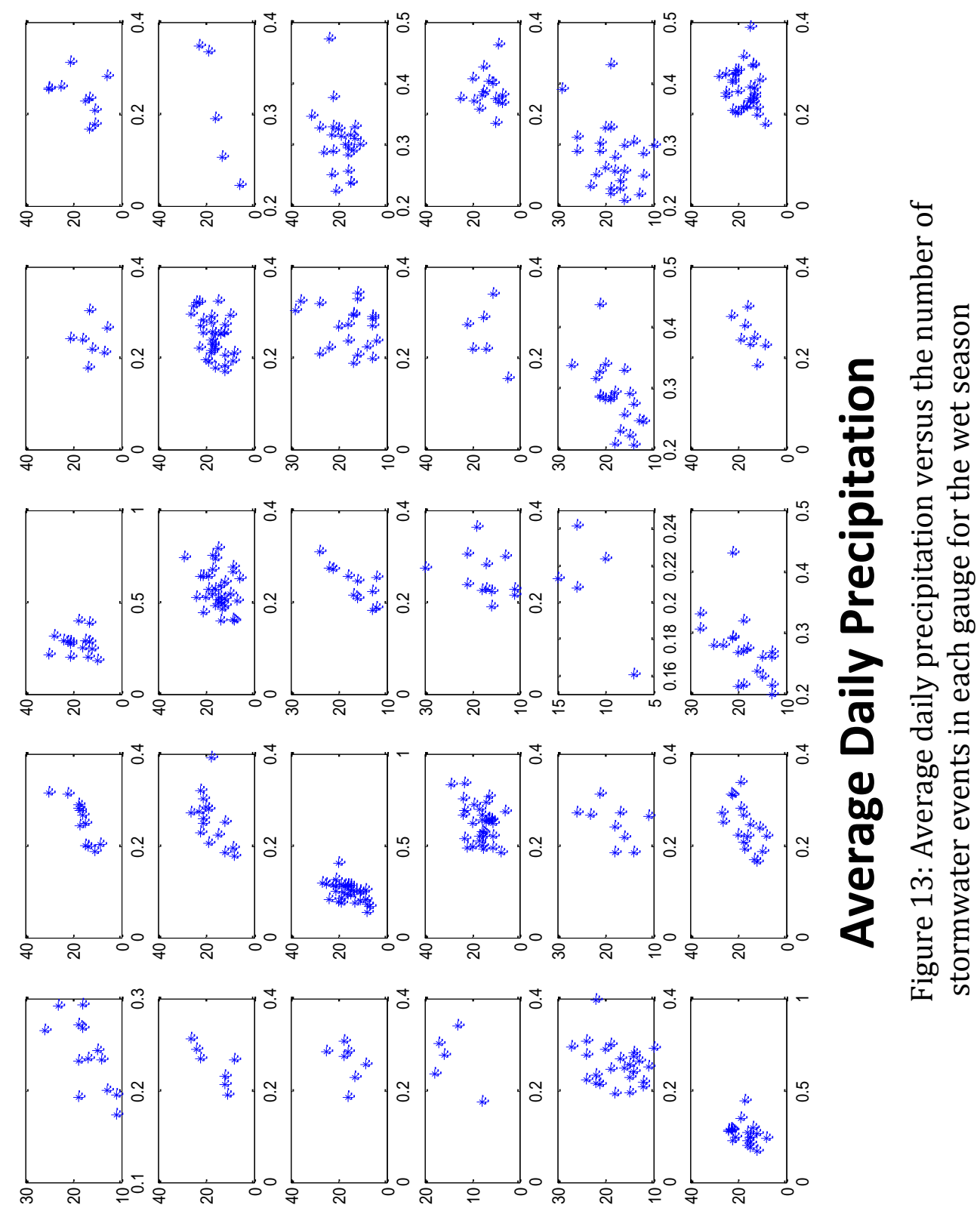

Number of Events 

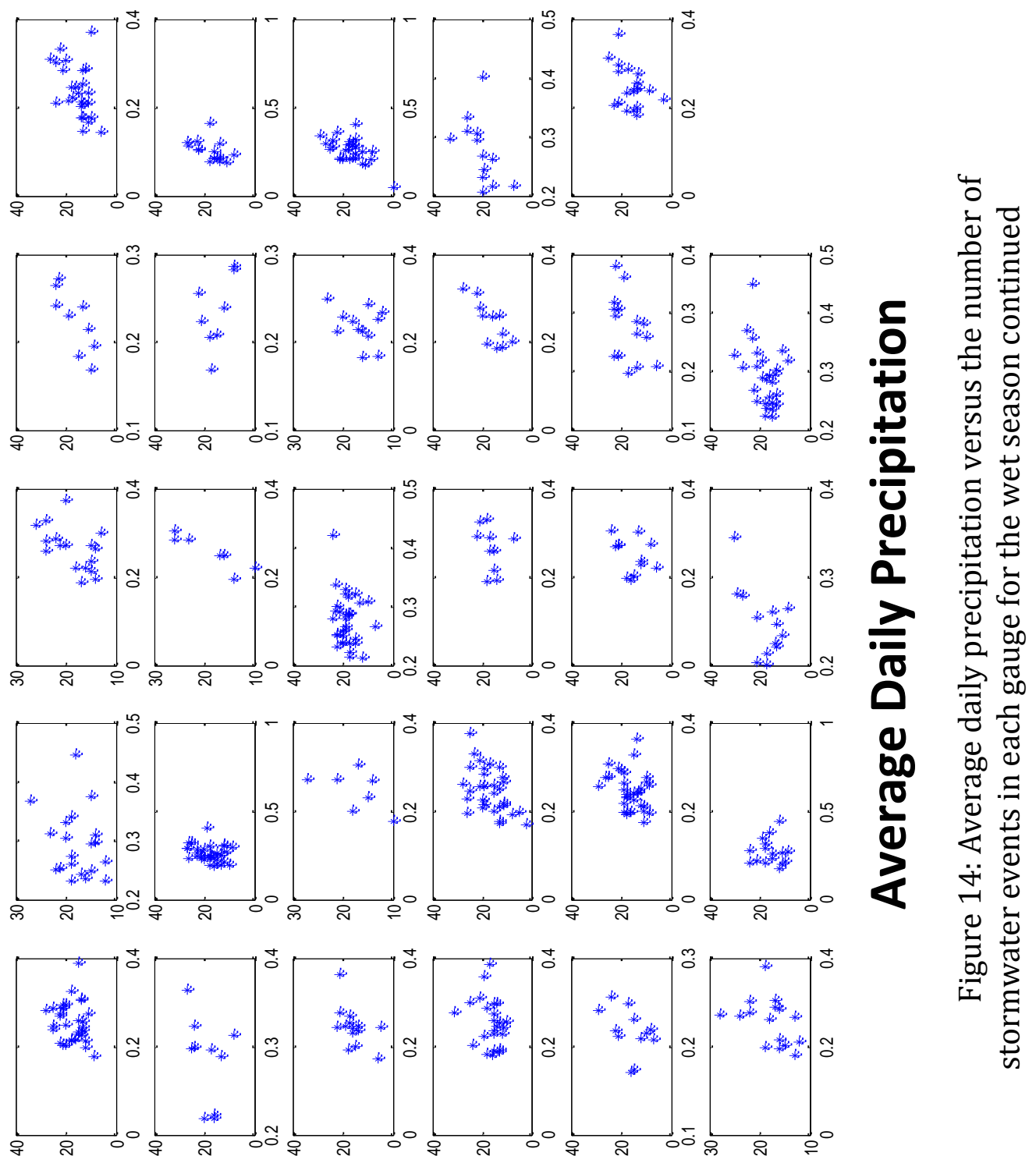

Number of Events 
The calculated correlation coefficients for all gauges are shown as histograms for the dry and wet seasons in Figure 15 Total number of 59 gauges is used for this analysis. The reason all 66 gauges were not used was because some of the gauges either work for a very short period, or they only had data for a few of the years, casting them as outliers. Any gauge with four or fewer GYC was not used in this section. Considering the dry season 21 gauges show significant correlations between the number of events and the average daily precipitation with correlations more than 0.5 . Regarding the wet season 20 gauges show correlations with values more than 0.5 . 

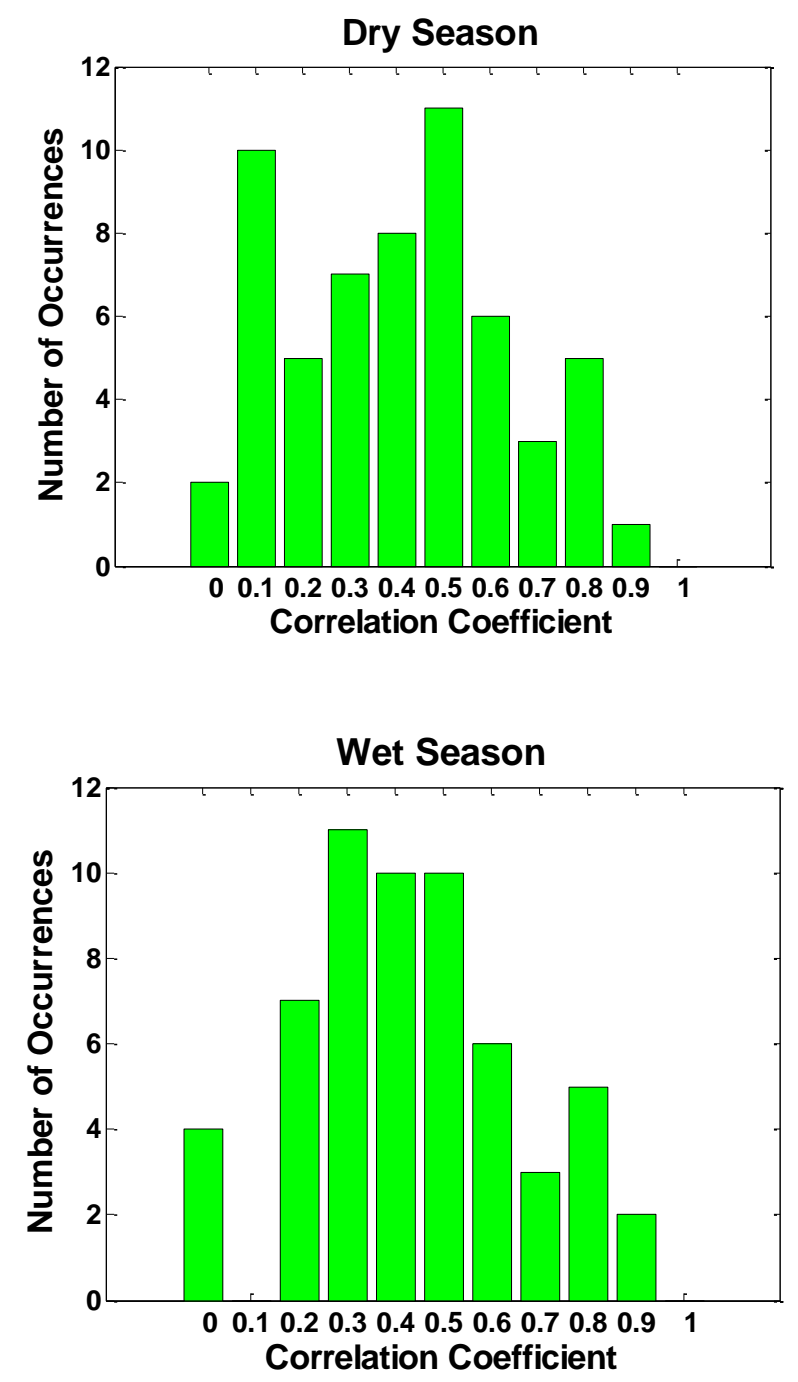

Figure 15: Histograms of the correlations between the average daily precipitation and the number of events for all gauges in the dry and wet seasons In order to estimate the average number of stormwater events of all gauges for each year, a Poisson distribution is used: 


$$
f(k ; \lambda)=\frac{\lambda^{\mathrm{k}} \mathrm{e}^{-\lambda}}{\mathrm{k} !}(\text { Equation } 2)
$$

Where $\lambda$ is the mean number of successes that occur; the Poisson probability is calculated by $f(k ; \lambda)$, and $\mathrm{k}$ is the actual number of successes that result from the experiment, and is approximately equal to 2.72 .

The Poisson distribution has one parameter $\lambda$ which equals the mean of the distribution, hence by estimating this variable the mean number of events for all gauges was estimated for each year. Furthermore the probability of any number of events along with the confidence interval of the estimated mean can be obtained from the probability distribution. The average of the daily precipitation at all gauges in each year is then calculated which represent the spatial average of precipitation events in Portland. The plots of the mean of the Poisson distribution versus the spatial average precipitation for the dry and wet seasons suggest that the two variables are well correlated with each other with a $95 \%$ of confidence interval (figures 16, figure 17). The correlation for the dry season is higher compared with the wet season. This is not a problem because the main concern is with the number of events during the dry season, since they are considerably fewer compared to the wet season and it would be more challengeable to be able to sample those events. Figure 16 and figure 17 could be a good guide to estimate how many number of events should be expected during the dry or wet season. It will also help the city evaluate the number of events submitted by a vendor and verify if that was too high or too low compared to the estimations. 


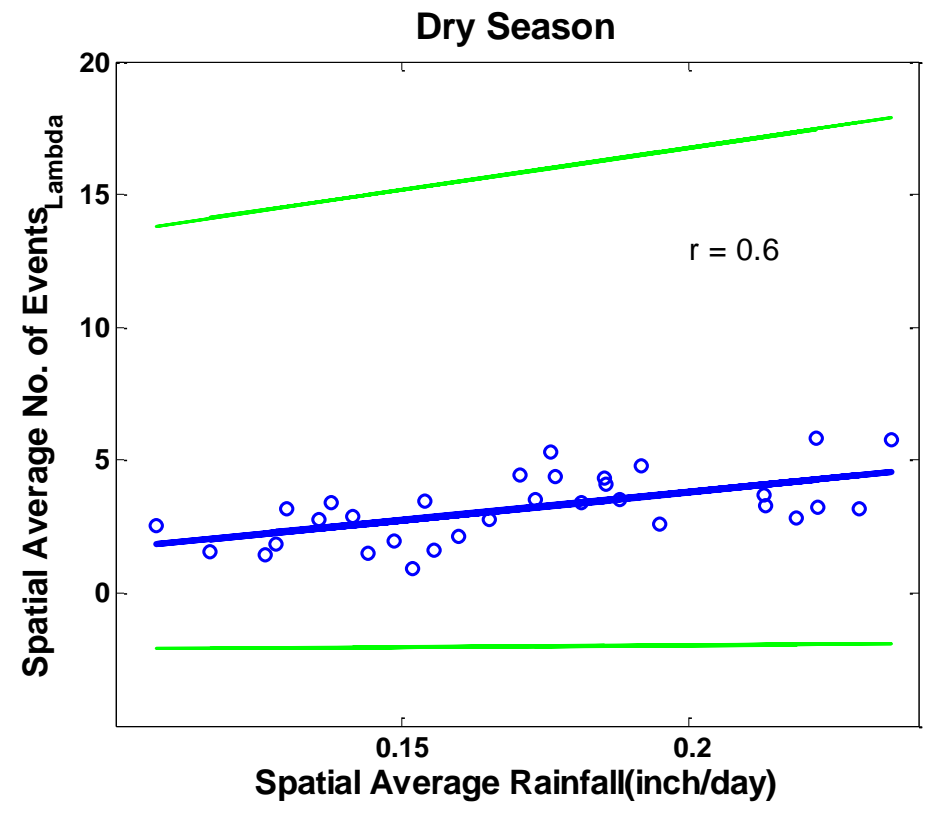

Figure 16: Correlation between the average number of events (Poisson $\lambda$ ) and the average daily precipitation for all gauges at each year in the dry season with a 95\% confidence interval. 


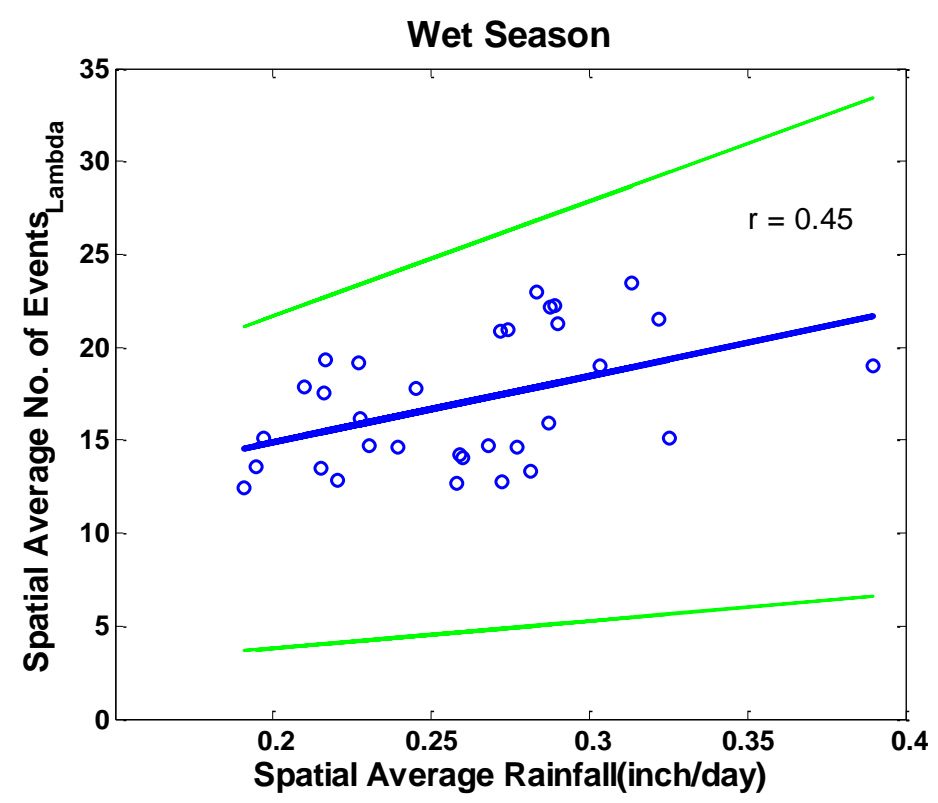

Figure 17: Correlation between the average number of events (Poisson $\lambda$ ) and the average daily precipitation for all gauges at each year in the wet season with a $95 \%$ confidence interval.

The fitted line for both wet and dry seasons follows these formulas:

For dry season $\lambda=(21.0$ average precipitation $)-0.41$

For wet season $\lambda=(35.5$ average precipitation $)+7.78$ 


\section{Comparing the effects of rainfall depth, intensity and duration on removal TSS}

\section{efficiency}

The goal of this section is to calculate if the restrictions on selecting a rainfall as an accepted event plays any part on how well a specific facility treats the samples of that certain rainfall. The calculations done in this section were on two data sets from two different vendors.

Most of the vendors whose data have been used here usually present their data which is valid by Washington requirements to the city of Portland. Among these data a minority is also accepted by Portland's requirements. If the vender is accepted by the state of Washington, the efficiency results for removing total suspended solids will pass the requirements of Portland. The main problem is with the events, since Portland aims for a higher standard than Washington regarding on accepting a rainfall as an event.

The first question which needs to be answered is whether the rules which strict the events, have any effect on the efficiency. Three rules which have a direct effect on which rainfalls can be accepted as an event are:

1. Storm depth (The minimum storm depth is 0.12 inches for Portland and 0.15 inch Washington)

2. Storm intensity ( Portland requires a Minimum storm intensity of $0.02 \mathrm{in} / \mathrm{hr}$ with $50 \%$ exceeding $0.03 \frac{i n}{h r}$ and $10 \%$ to exceed $0.05 \frac{i n}{h r}$ and Maximum 
average rainfall intensity of $0.1 \frac{i n}{h r}$, Washington doesn't restrict a minimum, but requires to sample different ranges of intensities. )

3. runoff duration (Minimum runoff duration should be six hours for Portland and one hours for Washington)

Keep in mind that storm depth can be calculated by having storm intensity and storm duration, the correlation between TSS efficiency, storm duration and storm intensity, storm depth and no rain event for six hours before and after an accepted rainfall was calculated.

Two sets of data from two different vendors were available. Both sets were taken place in state of Washington, and both include two different land uses.

The results for the two venders can be found in figures 18 and 19: 


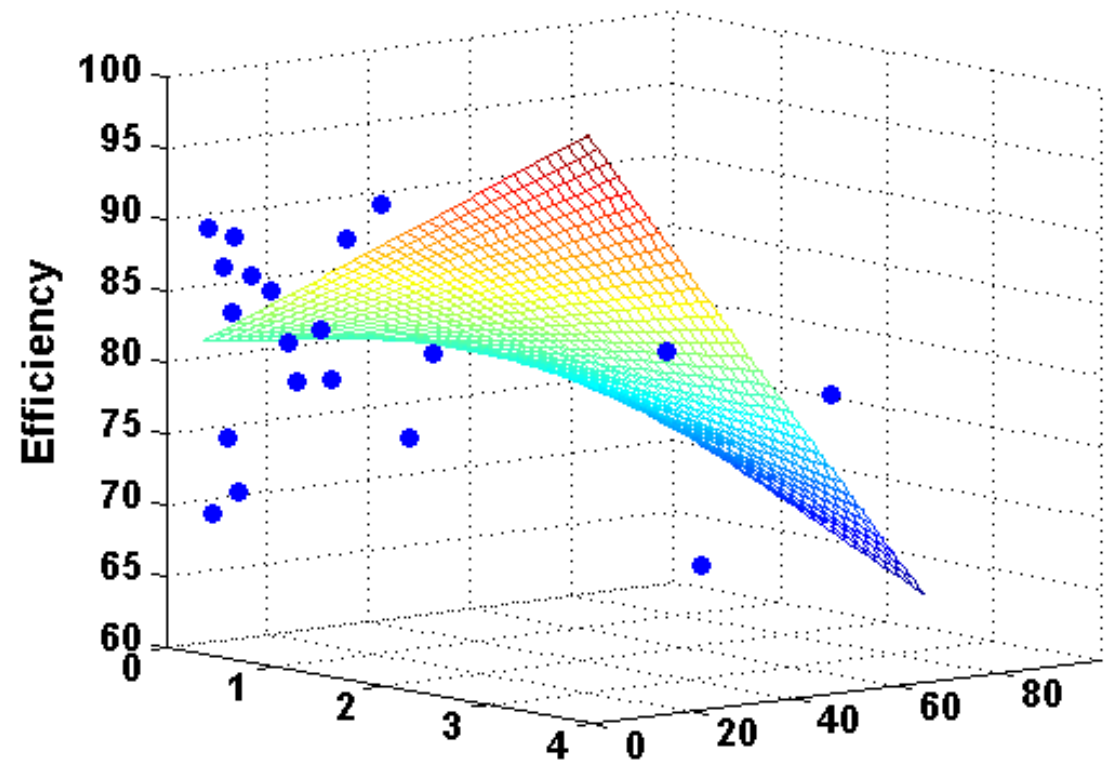

Storm Depth

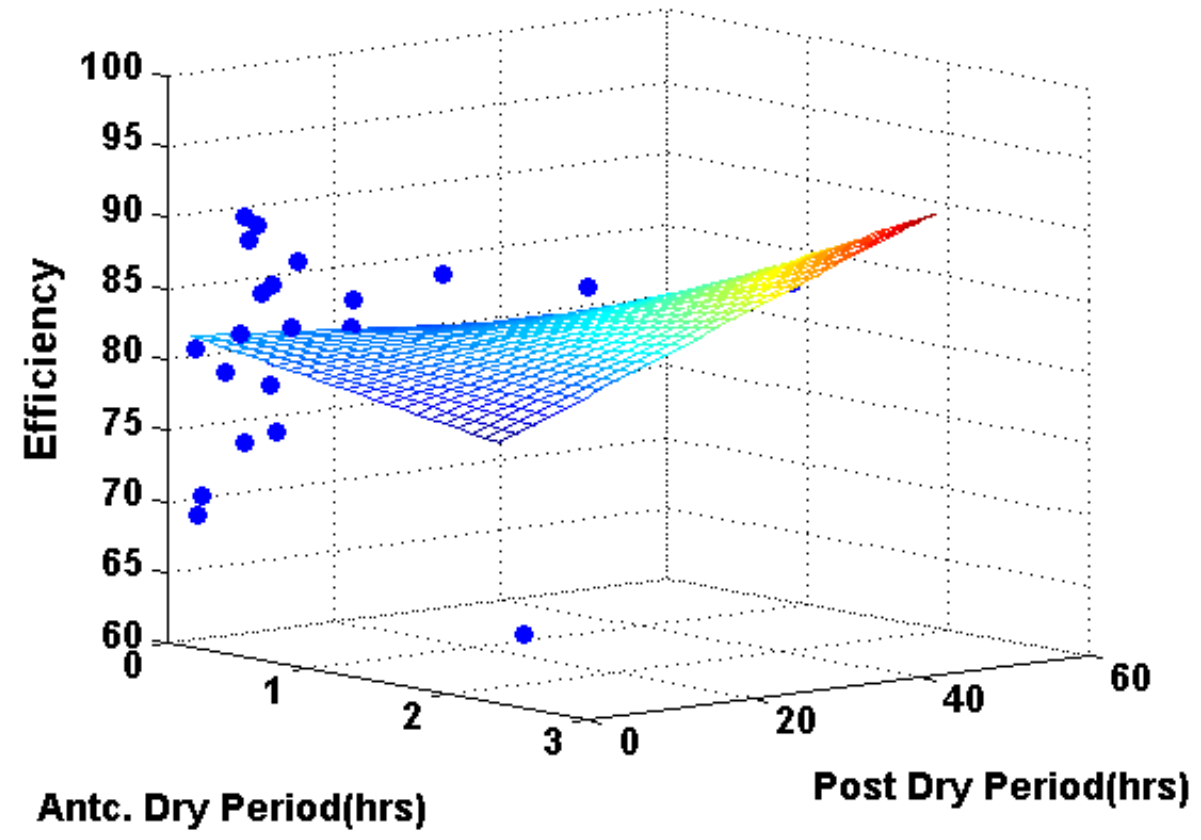

Figure 18: comparing the effects of storm depth, storm duration and antecedent dry periods on TSS removal efficiency in vendor 1 

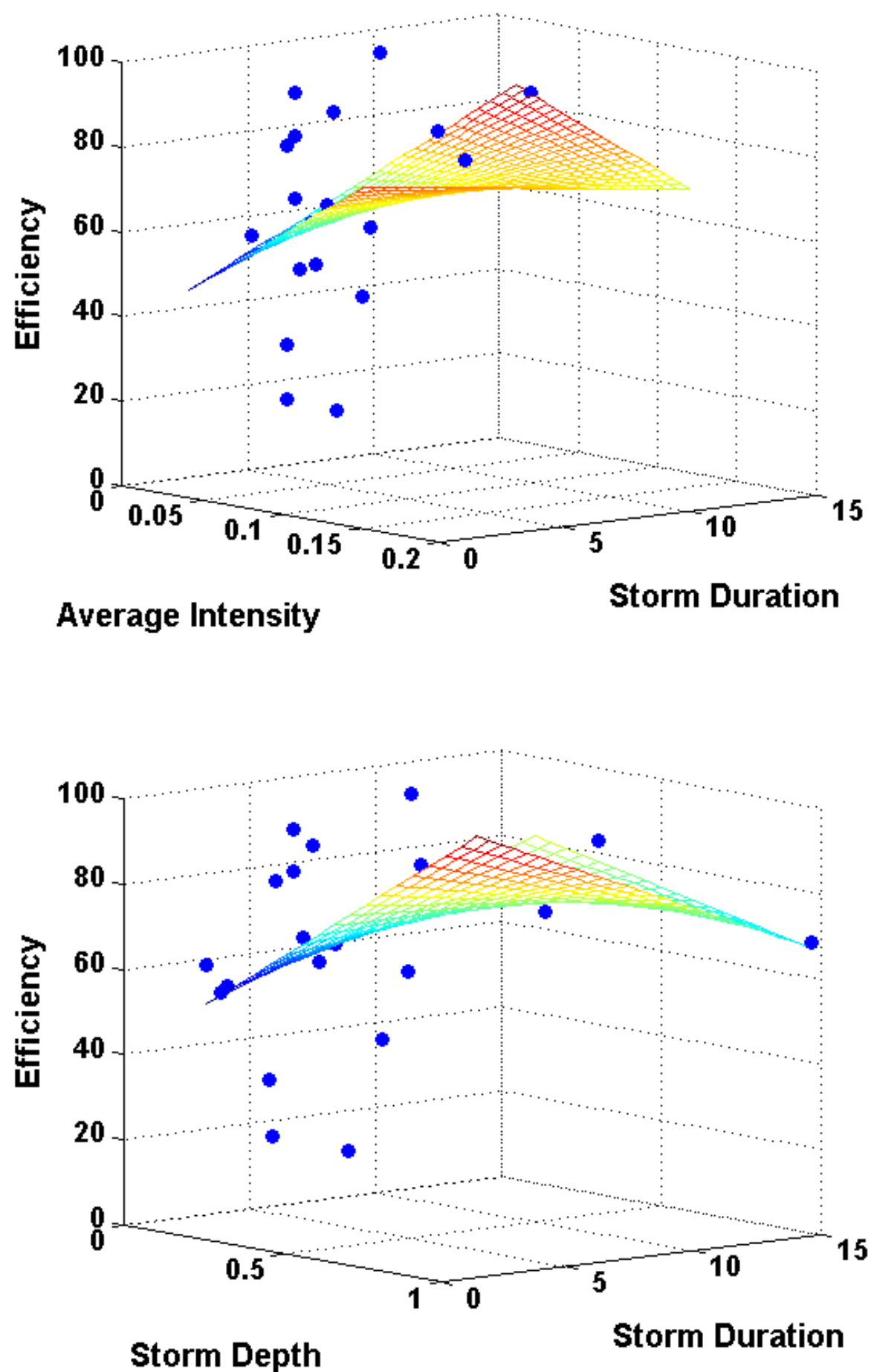

Figure 19: comparing the effects of storm depth, storm duration and storm intensity on TSS removal efficiency in vendor 2 
For the first vendor, first, correlation between depth, duration and efficiency were calculated and then the correlation between no rain for six hours before an event and after it was calculated.

For the second vendor, correlation between depth, duration and efficiency were calculated and then the correlation between duration and intensity was calculated.

The result can be found in table 6:

Table 6: results of the correlation for vendor 1 and 2

\begin{tabular}{llllll}
\hline Vendor one & R2 & R & F-stat & p-value & $\begin{array}{l}\text { error } \\
\text { variance }\end{array}$ \\
\hline $\begin{array}{l}\text { Depth, duration and } \\
\text { efficiency }\end{array}$ & 0.1384 & 0.372022 & 0.9638 & 0.4313 & 49.7737 \\
$\begin{array}{l}\text { Antc, post period and } \\
\text { efficiency }\end{array}$ & 0.0239 & 0.154596 & 0.1467 & 0.9304 & 56.3898 \\
& & & & & \\
\hline $\begin{array}{l}\text { Vendor two } \\
\text { duration and depth and }\end{array}$ & 0.1285 & 0.358469 & 0.8357 & 0.4927 & 522.7282 \\
$\begin{array}{l}\text { efficiency } \\
\text { duration and intensity } \\
\text { and efficiency }\end{array}$ & 0.1177 & 0.343074 & 0.7556 & 0.5343 & 529.2513 \\
\hline
\end{tabular}


As it can be seen from the results, none of the parameters have any correlation. This means that in this study, the rainfall restrictions don't affect the TSS efficiency. Assuming all the other differences are solved ( land use, number of sites, etc.), city of Portland can judge on the amount of TSS efficiency without considering that these parameters (depth, duration, no rain for six hours before an event and after, intensity) have not followed Portland's rules for these two vendors. If more vendors' data were available, a more general conclusion could be achieved. It is strongly advised to collect more data from more vendors and revisit this section with the new data. 


\section{Land Use}

Many studies have been done on the effects of land use on stormwater. (Minton, 2002) There is a general agreement among the researchers that the runoff volume differs among land uses because of the fraction of impervious surfaces. However, there is a lack of agreement that contaminant concentrations differs in a systematic way. Some studies have shown that, for some pollutants such as BOD, nitrogen, phosphorus, lead, zinc and some pesticides, there is difference between commercial, residential and industrial sites.(Athayde, 1984; USEPA, 1983) Some studies have also found that metals in the commercial areas are usually higher than the residential areas. Another study, which has been named as the most complete study, had storms sampled from 28 cities with a range of 4 to 39 different land uses of a total of 81 sites. The study suggested that there was no substantial difference between mean concentrations of pollutants for different land uses, except for the open space; and that land use is not a good predictor of concentration. According to Appendix B, the data should come from three different land uses. This study suggested that the variation of concentration is seen within the land uses rather than between them. According to that study, the reason for the difference in the results of the studies mentioned before is that most studies don't use enough sites and/or use few storms.(Minton, 2002)

A similar study in the city of Austin has also come up with the same results. This study was done in three different land uses, there was between four to six 
different sites for each land use and 20 storms were sampled from each site. This study showed that there was not a significant difference for most of the pollutants among the three different land uses. However, zinc, COD, and copper were slightly different. The results can be seen in table 7 .

Table 7 : Difference between three land use types ( units are mg/Lexcept for fecal coliform which is count/(100 mls))

\begin{tabular}{cccc}
\hline Pollutant & $\begin{array}{c}\text { Single } \\
\text { family } \\
\text { residential }\end{array}$ & $\begin{array}{c}\text { Multifamil } \\
\text { y residential }\end{array}$ & $\begin{array}{c}\text { Comm } \\
\text { ercial/ } \\
\text { industrial }\end{array}$ \\
\hline TSS & 171 & 106 & 221 \\
BOD & 9 & 9 & 12 \\
Total & 2.02 & 2.12 & 2.49 \\
nitrogen & & & \\
Total & 0.29 & 0.34 & 0.45 \\
phosphorus & & & \\
Copper & 0.010 & 0.014 & 0.022 \\
Lead & 0.016 & 0.015 & 0.034 \\
Zinc & 0.049 & 0.079 & 0.149 \\
Fecal & 34970 & 71830 & 79850 \\
coliform & & &
\end{tabular}

Also notable is that similar land uses could have different levels of activities. As an example, consider a parking lot for a fast food and the parking lot of a wholesale commercial retail.

Another example is a study from the 1983 "Results of the Nationwide Urban Runoff Program: Volume 1 - Final Report" which was done in order to find whether there is a relationship between the event mean concentration (EMC) of a particular pollutant and land use. The land use categories were residential, mixed, 
commercial, and open, non-urban resulting in a total of 67 sites from 20 of NURP projects. This study was done for 9 different contaminants, but here we are discussing the results for TSS. Figure 16 shows box plots which give a good visual sense of whether there is significant difference between concentrations of TSS and land use. Table 8 shows the median EMC for all the sites in each land use. In this table, the coefficient of variation (CV) measures the dispersion of TSS for the sites in each land use category.

Table 8: Median and CV of TSS in the residential, mixed, commercial and open non-urban land uses

\begin{tabular}{|c|c|c|c|c|c|c|c|c|}
\hline \multirow{2}{*}{$\begin{array}{c}\text { Pollutant } \\
\text { (mg/L) }\end{array}$} & \multicolumn{2}{l|}{ Residential } & \multicolumn{2}{l|}{ Mixed } & \multicolumn{2}{l|}{ Commercial } & \multicolumn{2}{l|}{$\begin{array}{l}\text { Open, } \\
\text { urban }\end{array}$} \\
\cline { 2 - 9 } & Median & CV & Median & CV & Median & CV & Median & CV \\
\hline TSS & 101 & 0.96 & 67 & 1.14 & 69 & 0.85 & 70 & 2.92 \\
\hline
\end{tabular}

Figure 20 used this data and some additional data. According to figure 20 there is no significant difference between land use types for TSS. The forth category under "Open sites" is for rural areas. 


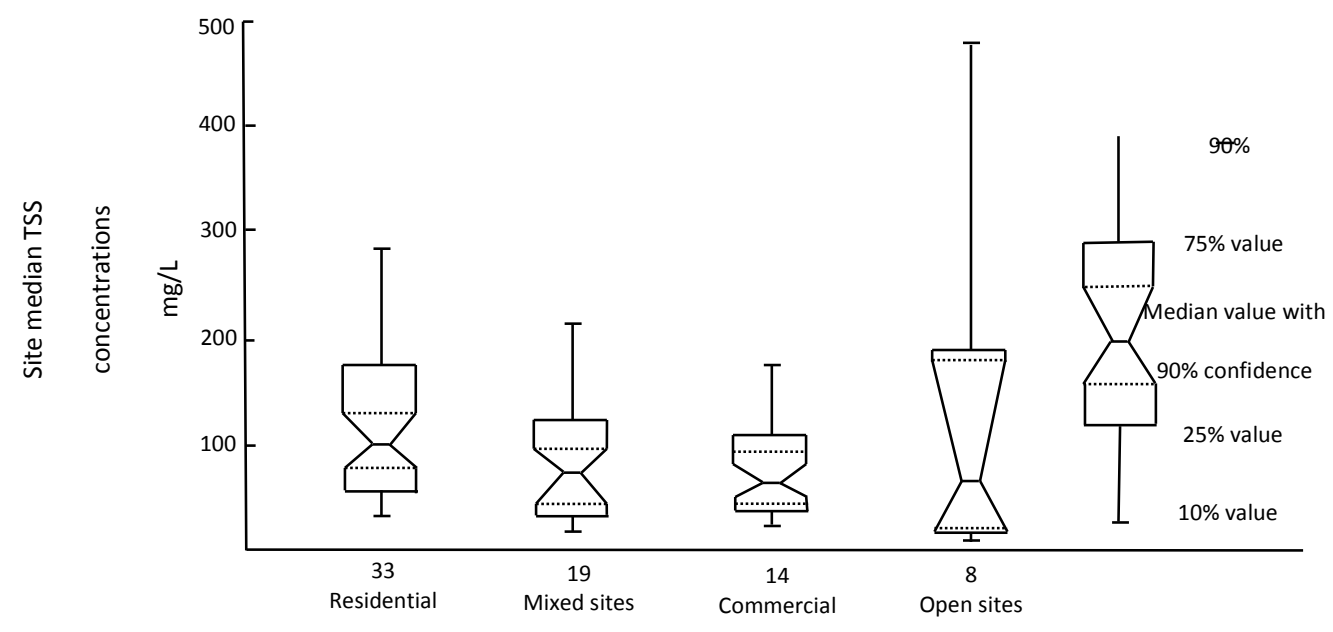

Figure 20: Variation in the event mean concentration of TSS between different land uses(USEPA, 1983) 


\section{Six Hourly Duration of No Rain Before and After a Rainfall Event}

The goal of this section is to study whether there is logical way to increase the number of acceptable events, especially during the dry season. The reason for this goal is that the average available events especially during the dry season for the 31 years period of data in this study were not enough ( we need at least 15 events, were no less than $30 \%$ of it is allowed in the wet or dry season.). If there were more available events, vendors will have a better chance to present their data and pass the rules required by Portland. Also, the more samples the vendors present the city, the more precise the City can decide which vendor is more suitable.

Portland requires as discussed in chapter 4 that an event used in equipment testing by vendors should have at least a six hour period of no rain before and after the rain event.

Shortening the antecedent no-rain period from 6 hours to something less would make it easier to field-test facilities. This section presents a quantitative assessment of the actual increases in usable events when the antecedent dry period is reduced.

As shown in the histograms in Figure 21, reducing the antecedent no-rain period from 6 hours to 2 hours in 1 hour steps increases the total number of acceptable events but also alters somewhat the distribution of the events. 


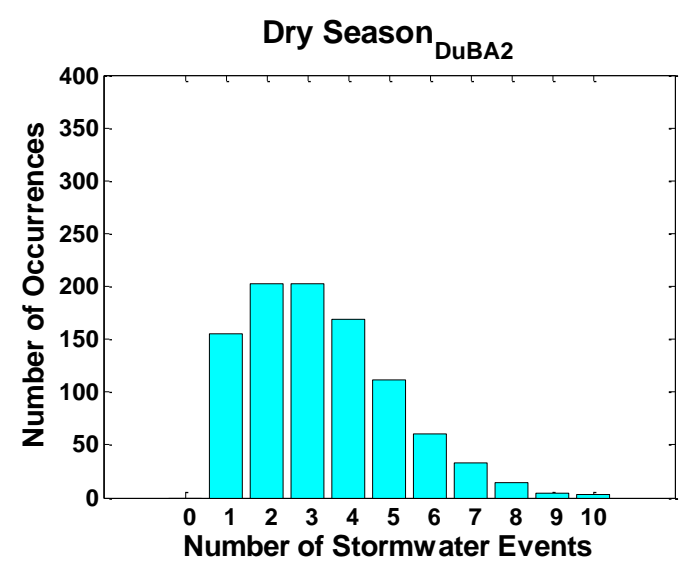

a. Two hours of no rain before and after the event adjusted to the 30\%$70 \%$ criterion

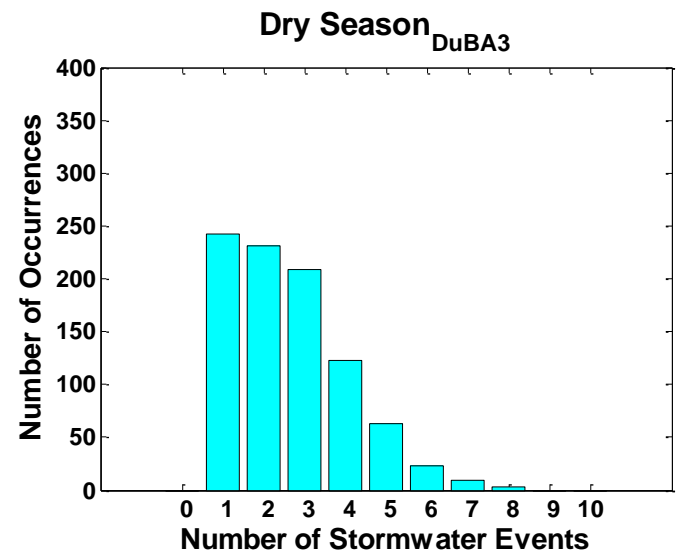

c. Three hours of no rain before and after the event adjusted to the 30\%$70 \%$ criterion

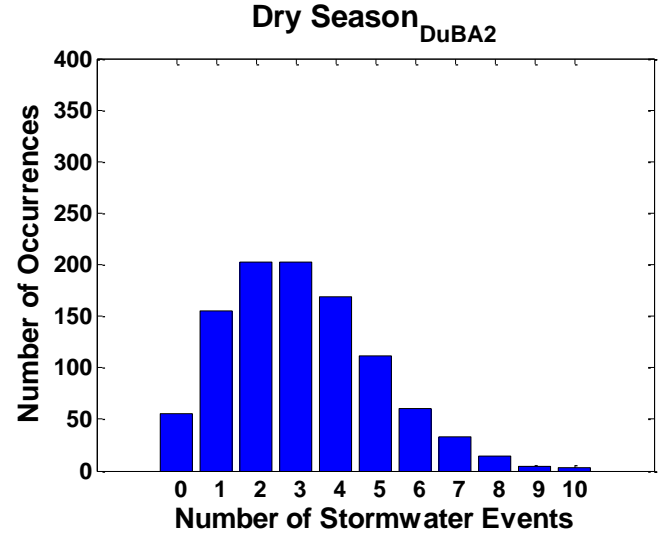

b. Two hours of no rain before and after the event.

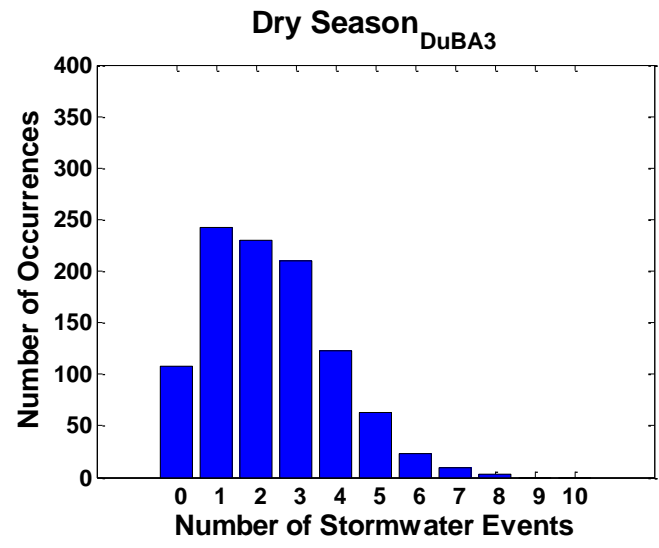

d. Three hours of no rain before and after the event. 


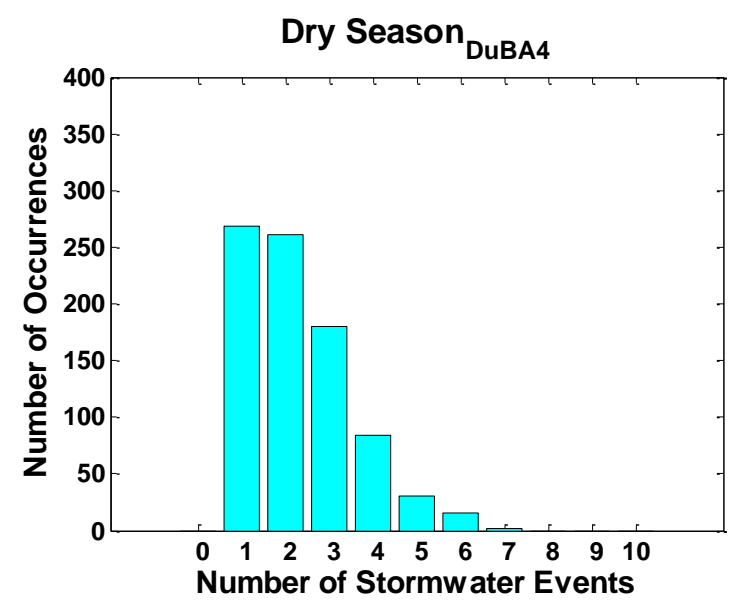

e. Four hours of no rain before and after the event adjusted to the $30 \%$ $70 \%$ criterion

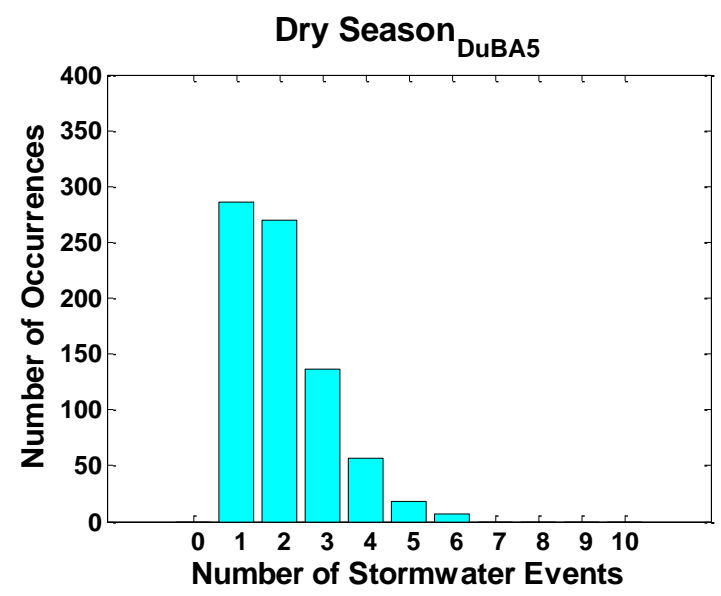

g. Five hours of no rain before and after the event adjusted to the 30\%$70 \%$ criterion

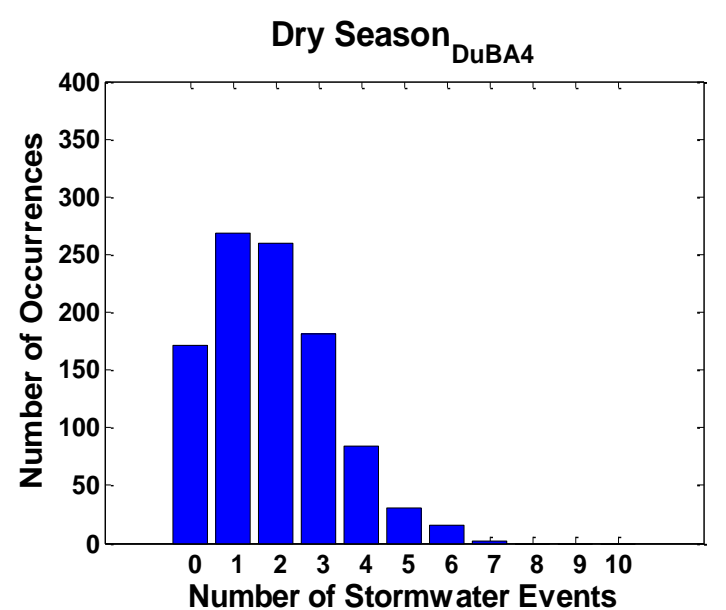

f. Four hours of no rain before and after the event.

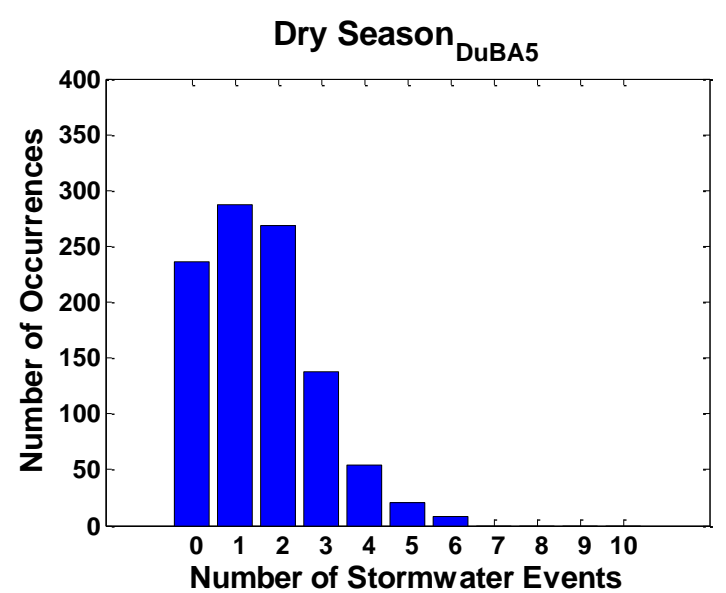

h. Five hours of no rain before and after the event.

Figure 21: Histogram of the total number of events per gauge per year during the dry season 
Table 9 presents the total numbers of dry season events available for testing after reducing the number of hours of no rain before and after a rain event. It is obvious that reducing even one hour of no rain before and after a rain event, elevate the number of acceptable events by 527. Even though it is not recommended to reduce the before and after no rain event to two hours, but reducing to four hours would nearly increase the number of suitable test events by 1.5 times.

Table 9: Change in the available number of stormwater events by decreasing the no-rain duration before and after an event criterion for the dry season

\begin{tabular}{cccc}
$\begin{array}{c}\text { No-Rain Duration } \\
\text { Before/After (hr) }\end{array}$ & $\begin{array}{c}\text { Total Number in } \\
\text { Dry Season }\end{array}$ & $\begin{array}{c}\text { Total Number in Dry Season } \\
(30 \%-70 \% \text { Criterion })\end{array}$ & $\Delta \mathrm{N}$ \\
\hline $\mathbf{6}$ & 1072 & 1067 & - \\
$\mathbf{5}$ & 1601 & 1594 & 527 \\
$\mathbf{4}$ & 1921 & 1920 & 853 \\
$\mathbf{3}$ & 2364 & 2363 & 1296 \\
$\mathbf{2}$ & 3172 & 3172 & 2105 \\
\hline
\end{tabular}

Similar results were achieved for the wet season: 


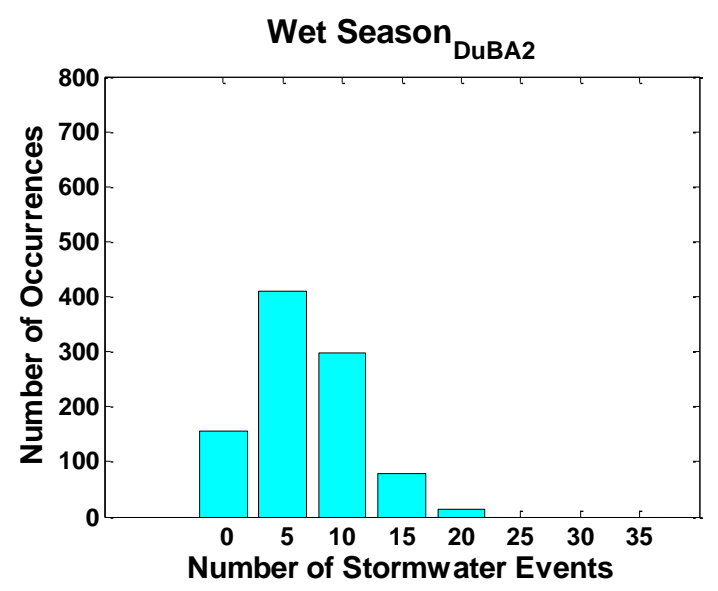

a. Two hours of no rain before and after the event adjusted to the 30\%$70 \%$ criterion

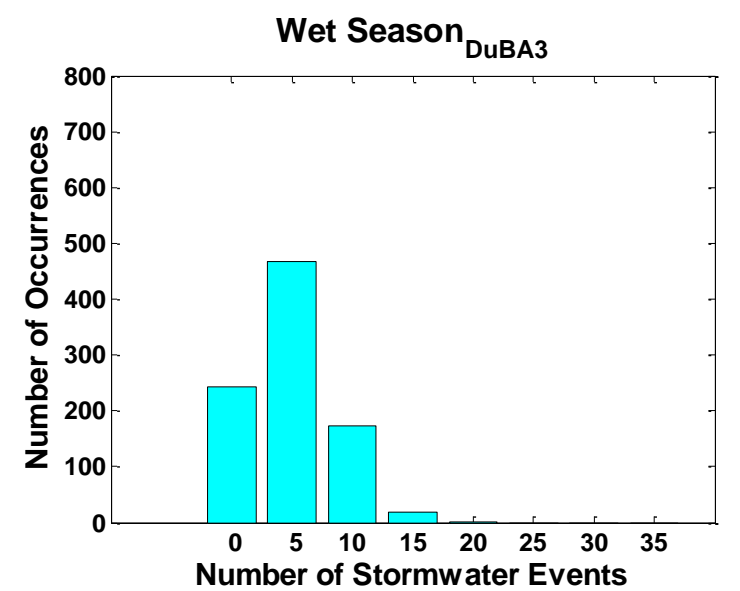

c. Three hours of no rain before and after the event adjusted to the 30\%$70 \%$ criterion

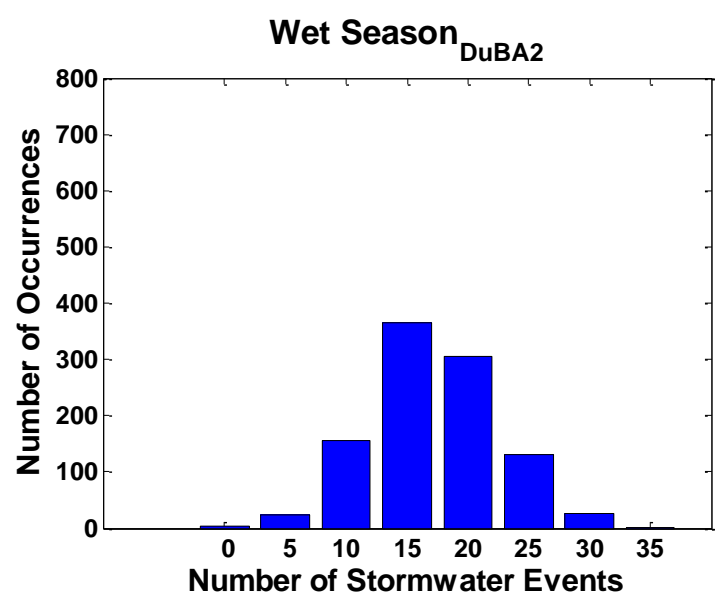

b. Two hours of no rain before and after the event.

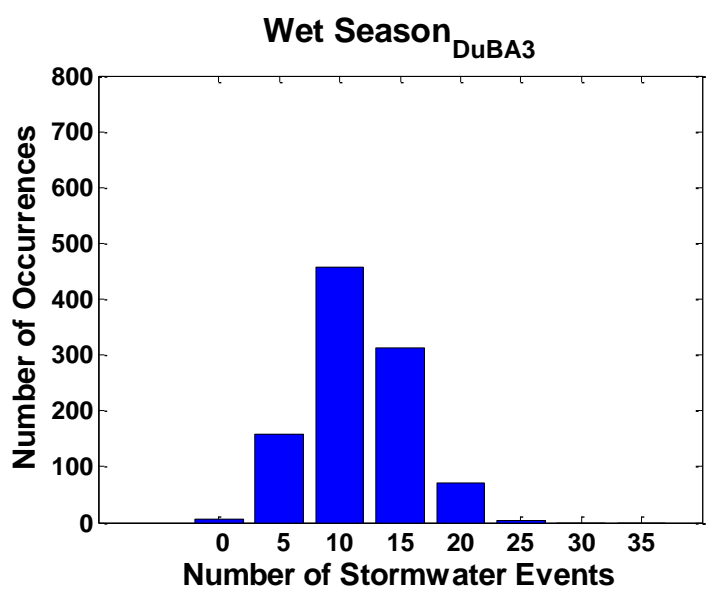

d. Three hours of no rain before and after the event. 


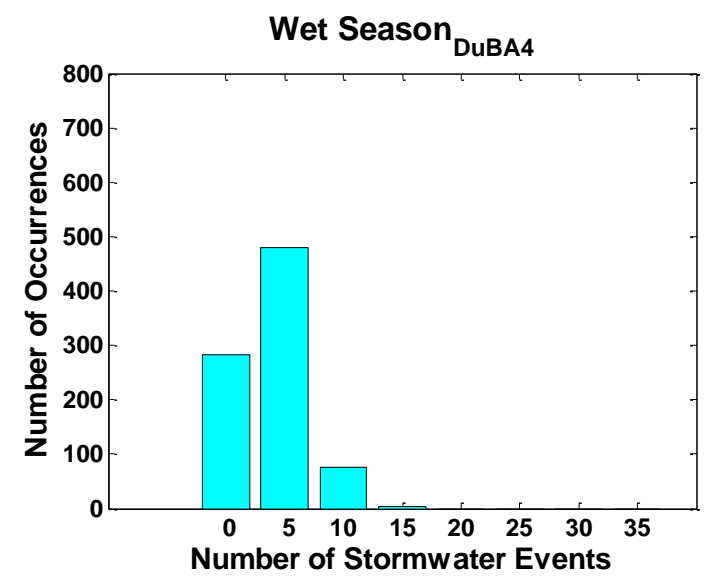

e. Four hours of no rain before and after the event adjusted to the $30 \%$ $70 \%$ criterion

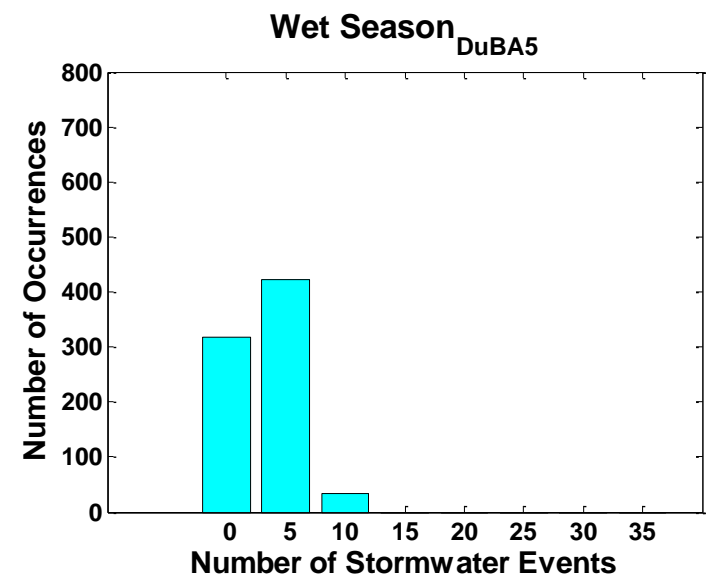

g. Five hours of no rain before and after the event adjusted to the $30 \%$ $70 \%$ criterion

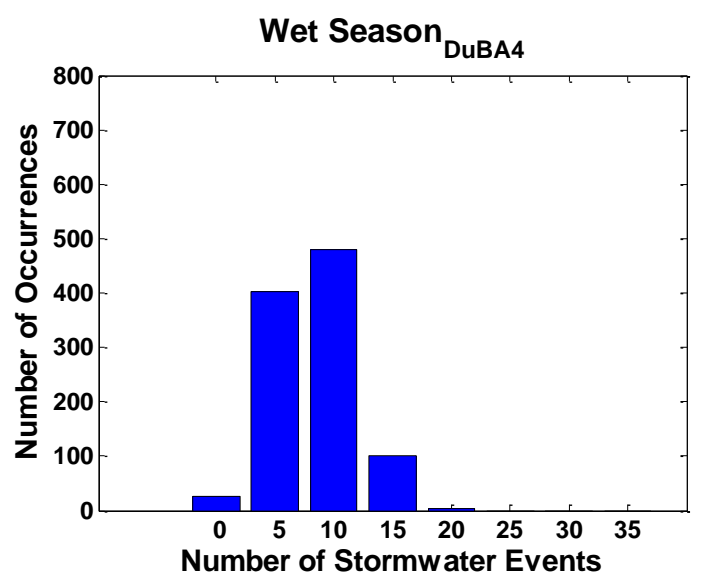

f. Four hours of no rain before and after the event.

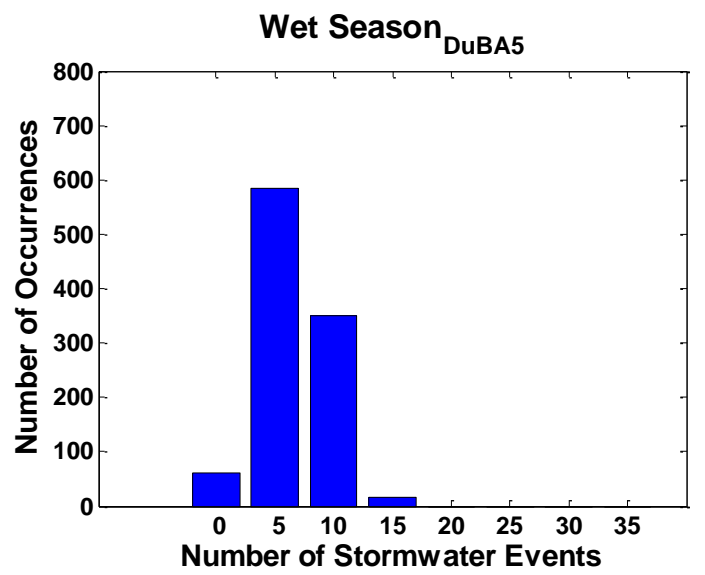

h. Five hours of no rain before and after the event.

Figure 22: Histogram of the total number of events per gauge per year during the wet season 
Table 10 shows that similar results were achieved after reducing the number of hours of no rain before and after a wet season rain event. As with the dry season, a reduction to 4 hours of no rain before/after would roughly double the number of suitable test events.

Table 10: Change in the available number of stormwater events by decreasing the no-rain duration before and after an event criterion for the wet season

\begin{tabular}{cccc}
\hline $\begin{array}{c}\text { No-Rain Duration } \\
\text { Before/After (hr) }\end{array}$ & $\begin{array}{c}\text { Total Number } \\
\text { in Wet Season }\end{array}$ & $\begin{array}{c}\text { Total Number in Wet } \\
\text { Season }(30 \%-70 \% \\
\text { Criterion) }\end{array}$ & $\Delta \mathrm{N}$ \\
\hline $\mathbf{6}$ & 4616 & 1844 & - \\
$\mathbf{5}$ & 6540 & 2882 & 1038 \\
$\mathbf{4}$ & 8363 & 3722 & 1878 \\
$\mathbf{3}$ & 11513 & 4886 & 3042 \\
$\mathbf{2}$ & 17332 & 6895 & 5051 \\
\hline
\end{tabular}

\section{Connecting Events with 1 Hour Interevent Periods}

This section is concentrated on increasing the number of accepted events based on Portland's requirements. This increase will result in more samples from the vendors and there for a better chance to select the best vendor.

When considering Portland's weather conditions, it is noticed that in Portland we get a lot of "drizzles". In the National Weather Service Website (http://www.nws.noaa.gov), drizzle is defined as rain drops with less than $0.5 \mathrm{~mm}$ in diameter with a rainfall rate of $0.03 \frac{i n}{h r}$ or less. In The Weather Networks website (http://www.theweathernetwork.com) it is said that "drizzle doesn't need an umbrella". The drizzle phenomenon means that many events that are nominally 
separated by short "no rain" periods. In the 31 year Portland rainfall records there are a considerable number of rain events that started after 6 hours or more of no rain event, lasted 3 or more hours, then no rain was reported by the gauge for an hour, and again after that a rain fall was recorded for 2 or more hours, and after that, there was no rain recorded again for 6 or more hours. The following is the pattern: No rain for 6 or more hours-> 3 or more hours of rain-> no rain recorded for 1 hour-> 2 or more hours of rain-> No rain for 6 or more hours

Since the one hour of no rain was in between two rain events with considerable rain, it could be assumed to consider that one-hour periods as a drizzle. Note that such a situation results in two events that are too short ( $<6$ hours) to use under the existing testing criteria, but if they are merged into a single event, it becomes an acceptable 6 hour event. The merged are termed "1hrNS" (for 1 hour of no storm).

Figure 23 shows what happened when these extra events were added: 

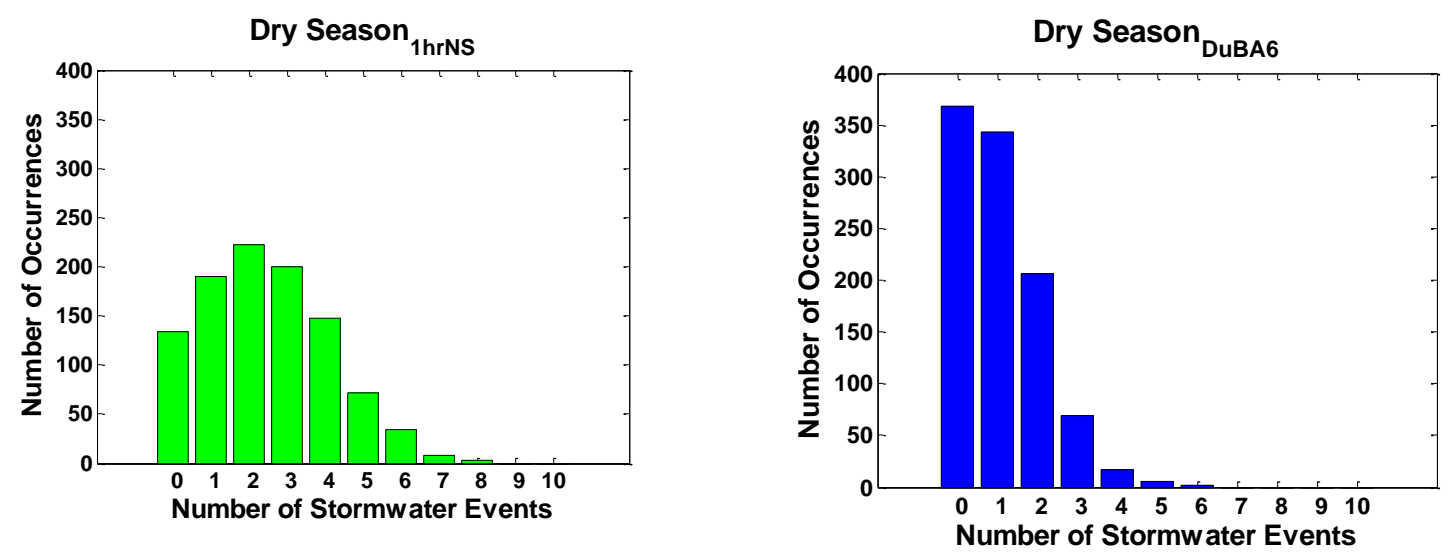

a. Disregarding one hour of no rain in between two acceptable events for the dry season.
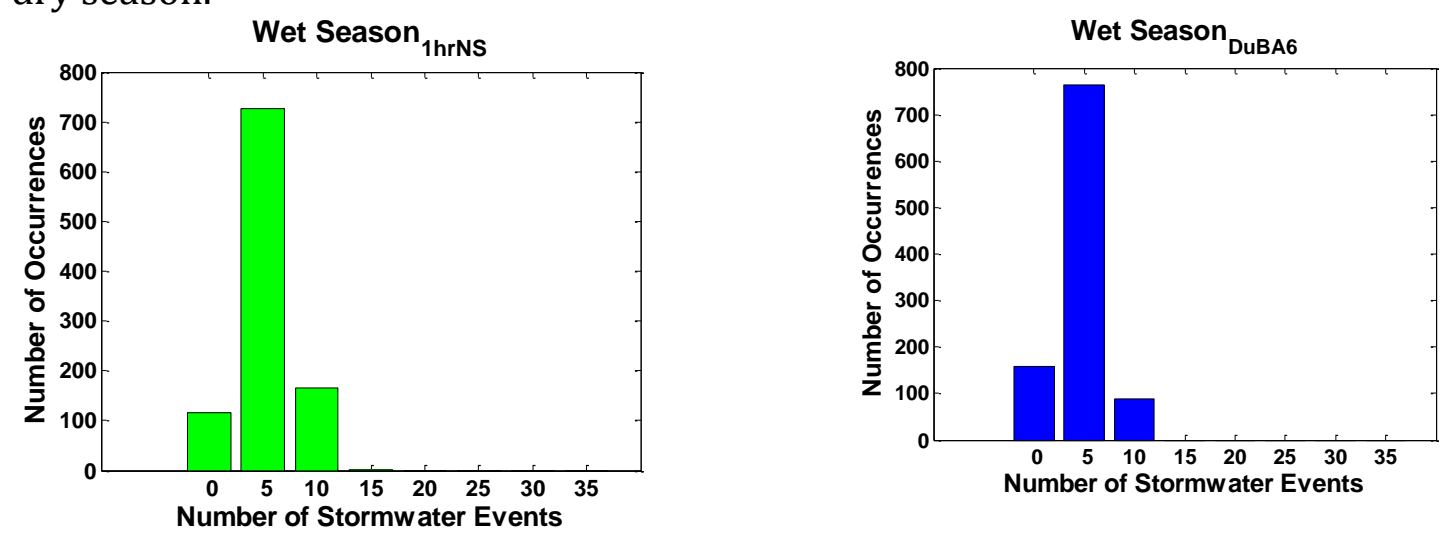

a. Disregarding one hour of no rain in between two acceptable events for the wet season.

b. Current criterion for the dry season.

b. Current criterion for the wet season.

Figure 23: Histogram of the total number of events per gauge per year

Figure 23 shows that adding the 1HrNS' make a considerable change during the dry season and not so much change during the wet season. This result is good, because it is observed that we have typically sufficient number of events for the wet season, but during the dry season the acceptable events are usually limited in numbers. Table 11 is a comparison of the number of events: 
Table 11: Change in the available number of stormwater events for different scenarios

\begin{tabular}{|c|c|c|c|c|c|c|}
\hline $\begin{array}{l}\text { No-Rain } \\
\text { Before/Aft } \\
\text { er (hr) }\end{array}$ & $\begin{array}{l}\text { Total } \\
\text { Number } \\
\text { in Dry } \\
\text { Season }\end{array}$ & $\begin{array}{c}\text { Total } \\
\text { Number in } \\
\text { Dry Season } \\
\text { (30\%-70\% } \\
\text { Criterion) }\end{array}$ & $\Delta \mathrm{N}$ & $\begin{array}{c}\text { Total } \\
\text { Number in } \\
\text { Wet Season }\end{array}$ & $\begin{array}{c}\text { Total } \\
\text { Number in } \\
\text { Wet Season } \\
\text { (30\%-70\% } \\
\text { Criterion) }\end{array}$ & $\Delta \mathrm{N}$ \\
\hline 6 & 1072 & 1067 & $5 \overline{2} \overline{7}$ & 4616 & 1844 & - \\
\hline 5 & 1601 & 1594 & 853 & 6540 & 2882 & $\begin{array}{l}38 \\
18\end{array}$ \\
\hline 4 & 1921 & 1920 & 1296 & 8363 & 3722 & $\begin{array}{l}78 \\
30\end{array}$ \\
\hline 3 & 2364 & 2363 & 2105 & 11513 & 4886 & $\begin{array}{l}42 \\
50 \\
51\end{array}$ \\
\hline $\begin{array}{l}1 \text { hour no } \\
\text { storm }\end{array}$ & 2470 & 2417 & 1350 & 5316 & 3470 & $\begin{array}{l}16 \\
26\end{array}$ \\
\hline
\end{tabular}

From the numbers, it is concluded that even though only about 700 events are added for all the years and all the gauges, (roughly about 0.34 event added per gauge per year), the number of events for the dry season have increased close to the condition where there is no rain for only three hours before and after each rain event, adding 1398 more events for all the years and all the gauges, (roughly about 0.68 event added per gauge per year). 


\section{Portland's Modified Performance Standard Line}

Considering the fact that the treatment device should give us the highest efficiency for the removal of total suspended solids, it is questioned whether some of the rules considered by city of Portland are actually helping the efficiency of the device to get higher. To examine this, first let us consider at the city of Portland's Modified Performance Standard Line (Figure 24). BES uses this following graph to calculate a technologies capability for treatment and removal of TSS.

According to Appendix B, Page B 1-16, at least 50\% of a treatment device's data points should fall on or above the Portland's Modified Performance Standard Line. For higher influent concentrations $(>130 \mathrm{mg} / \mathrm{L})$ it is required to remove more than $70 \%$ of the influent concentrations. For low $(<70 \mathrm{mg} / \mathrm{L})$ influent concentrations it is allowed to remove less than $70 \%$. The facilities that average $70 \%$ TSS removal during the design storm of 0.83 inches over 24 hours will receive acceptable performance evaluations. 


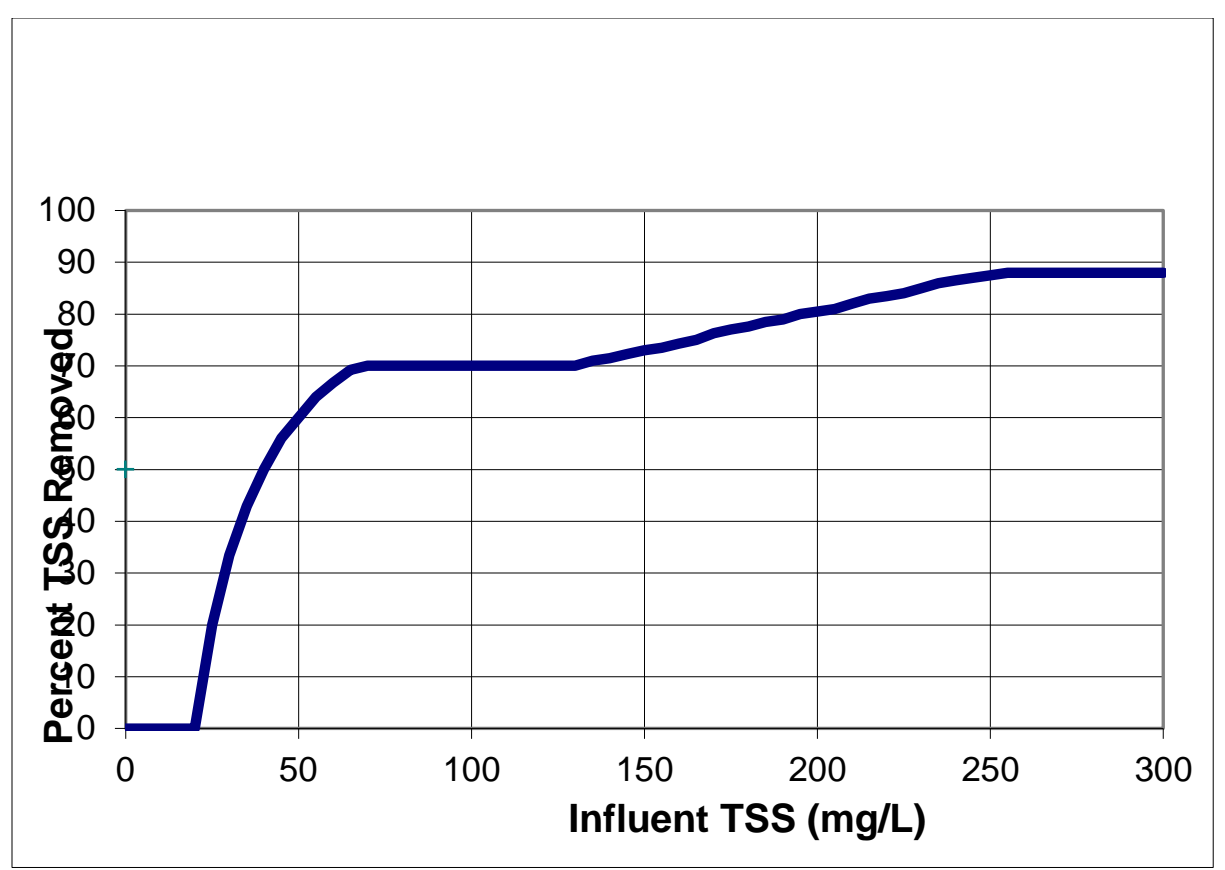

Figure 24: Portland's Modified Performance Standard Line

Table 12 describes the data points that form the Portland's Modified Performance Standard Line:

Table 12 :Portland's Modified Performance Standard Line data points [Portland Stormwater Management (2008)]

\begin{tabular}{|l|l|}
\hline Influent TSS & $\begin{array}{l}\text { Removal } \\
\text { efficiency }\end{array}$ \\
\hline 20 & $0 \%$ \\
\hline 25 & $20 \%$ \\
\hline 50 & $60 \%$ \\
\hline 75 & $74 \%$ \\
\hline 100 & $80 \%$ \\
\hline 125 & $83 \%$ \\
\hline 150 & $85 \%$ \\
\hline 175 & $87 \%$ \\
\hline 200 & $88 \%$ \\
\hline 250 & $89 \%$ \\
\hline & \multicolumn{2}{|c|}{74} \\
\hline
\end{tabular}


In order to see whether some of the initial hydrological properties needed for a rain event to be accepted actually have an effect on the final efficiency of the device I performed an experiment in which I separated the Portland's Modified Performance standard Line into three separate sections, fitting a graph on each part. The formula for graph of the trisected line will be used to predict the TSS removal efficiency for each event. Then, this prediction, along with the observation gathered for that specific point, are be used together to give us an indication for the expected efficiency. Three different methods for calculating errors are used in this section:

\section{Bias}

Bias (b) provides a good estimate of the differences between observation and our model simulation. Since bias gives the error with its sign, it is a very good indicator for our purpose. The bias (b) formula is:

$$
\mathrm{B}=\frac{\sum_{i=1}^{N}\left(S_{i}-O_{i}\right)}{N} \text { (Equation 3) }
$$

Where $\mathrm{N}$ is the number of data points, $\mathrm{S}$ is the simulation data and $\mathrm{O}$ is the observation data.

\section{RMSE (Root Mean Square Error)}

The root mean squared error is useful because it is more sensitive than other error measurement formulas to the occasional large error. The problem with RMSE 
is that it doesn't show the sign of the error. In other words it doesn't show whether the point is above the line or below the line. Below is the RMSE formula:

$$
\operatorname{RMSE}=\left[\frac{1}{N} \sum_{I=1}^{N}\left(S_{i}-O_{i}\right)^{2}\right]^{\frac{1}{2}} \text { (Equation 4) }
$$

Where $\mathrm{N}$ is the number of data points, $\mathrm{S}$ is the simulation data and $\mathrm{O}$ is the observation data. The results for RMSE errors are only shown to get a better sense of the larger differences. The Idea here was to first check the bias error to see whether the point is above or below the line, and then check the RMSE to see how big our error is, in case of a very large number.

The Portland's Modified Performance standard Line shows the TSS influent verses TSS removal efficiency. As long as a point falls above or on the line, the device has achieved a sufficient TSS removal efficiency for that point. In this case, the bias error should be positive. The higher amount of positive bias error states that the higher the point is above the "Modified Performance standard Line" and that that specific point has a higher efficiency. This same technique could also give us an average bias error for all the selected points.

A negative bias error means the point is below the Portland's Modified Performance standard Line, meaning that point has a lower efficiency than desired. This by itself does not mean that the device is not usable, since at least $50 \%$ of the points could be below the Portland's Modified Performance standard Line, but it could indicate whether adding that point is making our efficiency better or worst. 
Again the RMSE gives us a better indication of how large the error is especially that with a negative bias, this is very important.

\section{The t-test}

A t-test checks if the mean of two different sample groups are different from each other.

In order to use t-test, you need to have a null hypothesis. After having done the $t$-test, if the result for $\mathrm{t}$, or in MATLAB for $\mathrm{H}$, is 0 , it means that the $\mathrm{t}$-test could not reject the null hypothesis, and in fact the null hypothesis is correct. The formula for t-test is as follows:

$$
\mathrm{T}=\frac{\bar{X}_{T}-\bar{X}_{C}}{\sqrt{\frac{\operatorname{var}_{T}}{n_{T}}+\frac{v a r_{C}}{n_{C}}}} \text { (Equation 5) }
$$

Where $\mathrm{C}$ and $\mathrm{T}$ represent the two groups, $\bar{X}$ represent the mean of each group, var is the variance and $\mathrm{n}$ is the number of the data in each group.

In MATLAB, $\mathrm{h}=\operatorname{ttest} 2(\mathrm{x}, \mathrm{y})$ carries out the $t$-test of the null hypothesis. The null hypothesis states that data in the vectors $\mathrm{x}$ and $\mathrm{y}$ which resemble groups $\mathrm{x}$ and y are independent from each other, both have normal distributions with equal means variances. The alternative is that the means are not equal. The result of the test is returned in $h$. if $h=1$, then the null hypothesis is rejected at the $5 \%$ significance level; if $\mathrm{h}=0$ it indicates a failure to reject the null hypothesis at the $5 \%$ 
significance level. The two groups don't need to have the same number of data in them.

\section{Part I of trisected Portland's Modified Performance standard Line}

The first section of the trisected the Portland's Modified Performance Standard Line is divided in to three parts, the first part is for the points with a TSS influent between $20 \frac{\mathrm{mg}}{\mathrm{L}}$ to $65 \frac{\mathrm{mg}}{\mathrm{L}}$.

For this range there were two events accepted by Portland and 2 more events accepted by Washington. Using the equation 6 the simulated efficiency for each point was calculated by a binomial expression.

$$
y=-0.0365 x^{2}+4.513 x-72.028 \text { (Equation 6) }
$$

Using the Observation data and the calculated prediction data, the Bias and RMSE were calculated for the events accepted for Portland and then for the events accepted by both Portland and Washington. Those two events accepted by the city of Portland were also accepted by the state of Washington; as it turned out, for event points in this experiment, all the points accepted by the City of Portland were also accepted by the state of Washington.

After estimating the results for bias and RMSE errors I found that the bias for both two experiments were positive, meaning the average efficiency was higher than the standard line, but adding Washington's points actually made the bias even larger, meaning that the efficiency got higher: 


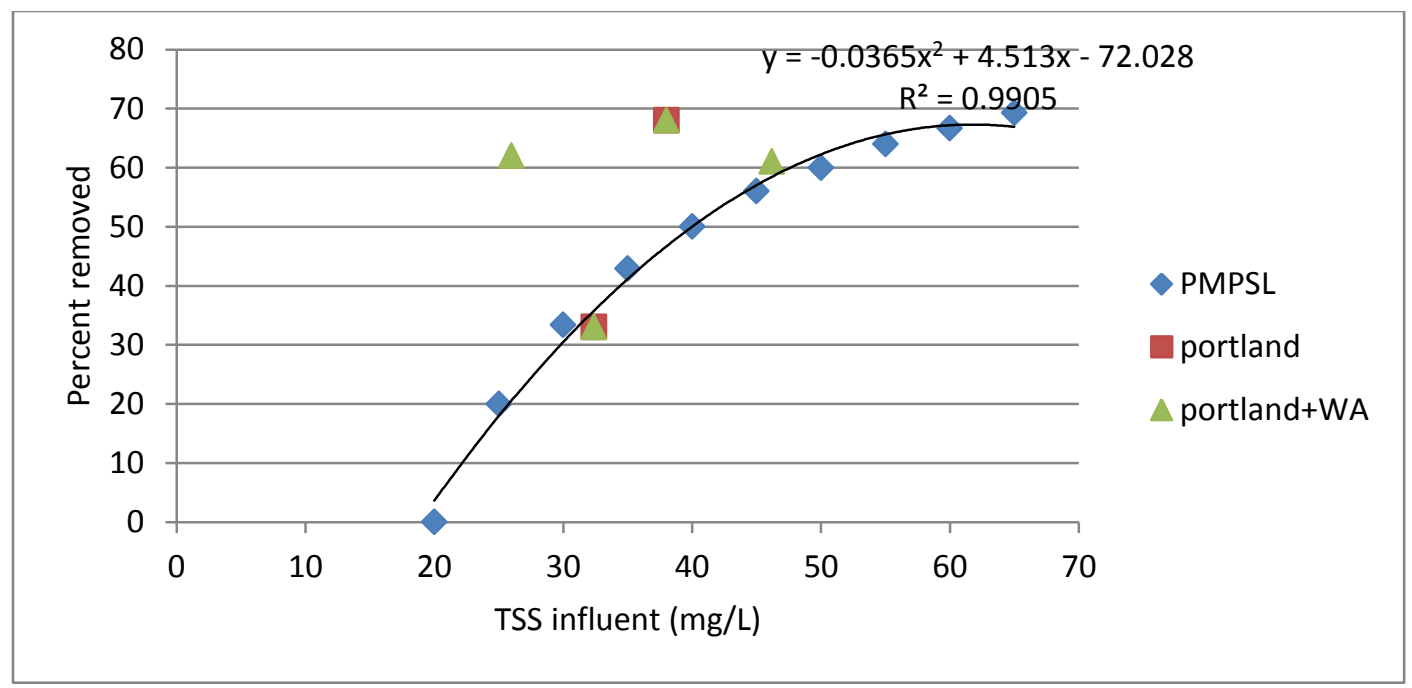

Figure 25: Part I of the Portland's Modified Performance standard Line

The points approved by Portland:

Table 13: RMSE and Bias results for acceptable events by Portland in part I of Portland's modified performance standard line

\begin{tabular}{lcccc}
\hline $\begin{array}{l}\text { TSS } \\
\text { influent }\end{array}$ & $\begin{array}{c}\text { Efficiency } \\
\text { (observation) }\end{array}$ & $\begin{array}{c}\text { Efficiency } \\
\text { (Simulation) }\end{array}$ & $\begin{array}{c}\text { RMSE } \\
\text { (ob-sim) }^{3}\end{array}$ & $\begin{array}{c}\text { Bias } \\
\text { Obs-sim }\end{array}$ \\
\hline 32.4 & 33 & 35.88 & 8.28 & -2.87 \\
38 & 68 & 46.76 & 451.14 & 21.24 \\
\hline
\end{tabular}

RMSE: 15.1561

Bias: $26.08 \%$

Table 14: RMSE and Bias results for acceptable events by Portland and Washington in part I of Portland's modified performance standard line

\begin{tabular}{lcccc}
\hline $\begin{array}{l}\text { TSS } \\
\text { influent }\end{array}$ & $\begin{array}{c}\text { Efficiency } \\
\text { (observation) }\end{array}$ & $\begin{array}{c}\text { Efficiency } \\
\text { (simulation) }\end{array}$ & $\begin{array}{c}\text { RMSE } \\
\text { (ob-sim) }\end{array}$ & $\begin{array}{c}\text { Bias } \\
\text { Obs-sim }\end{array}$ \\
\hline 32.4 & 33 & 35.87 & 8.28 & -2.87 \\
38 & 68 & 46.76 & 451.14 & 21.24 \\
46.2 & 61 & 58.56 & 5.93 & 2.43 \\
26 & 62 & 20.63 & 1710.98 & 41.36 \\
\hline
\end{tabular}

RMSE: 23.32

bias: $27.75 \%$ 
Comparing the two bias results we can see that bias error for Portland events (26.1) is lower than bias error for Washington+ Portland events (27.7). by only looking at the bias error in this part the two different sets of points do not have that much difference, but if we look at the RMSE error we see that they are quite different (RMSE error changed to 23.32 from 15.15), meaning now that Washington's data has improved the efficiency, the added points must have had a very high efficiency, considerably higher than the standard line. This is corroborated by looking at the data. Of course these results are based on the data from one vendor. It is strongly advised to collect more data from more vendors in order to get a more comprehensive result.

\section{Part II of Portland's Modified Performance standard Line}

This same result was gained for the second two parts of the trisected Portland's Modified Performance standard Line. Part II of the Portland's Modified Performance standard Line was for TSS influents between $65 \mathrm{mg} / \mathrm{L}$ and $130 \mathrm{mg} / \mathrm{L}$. 


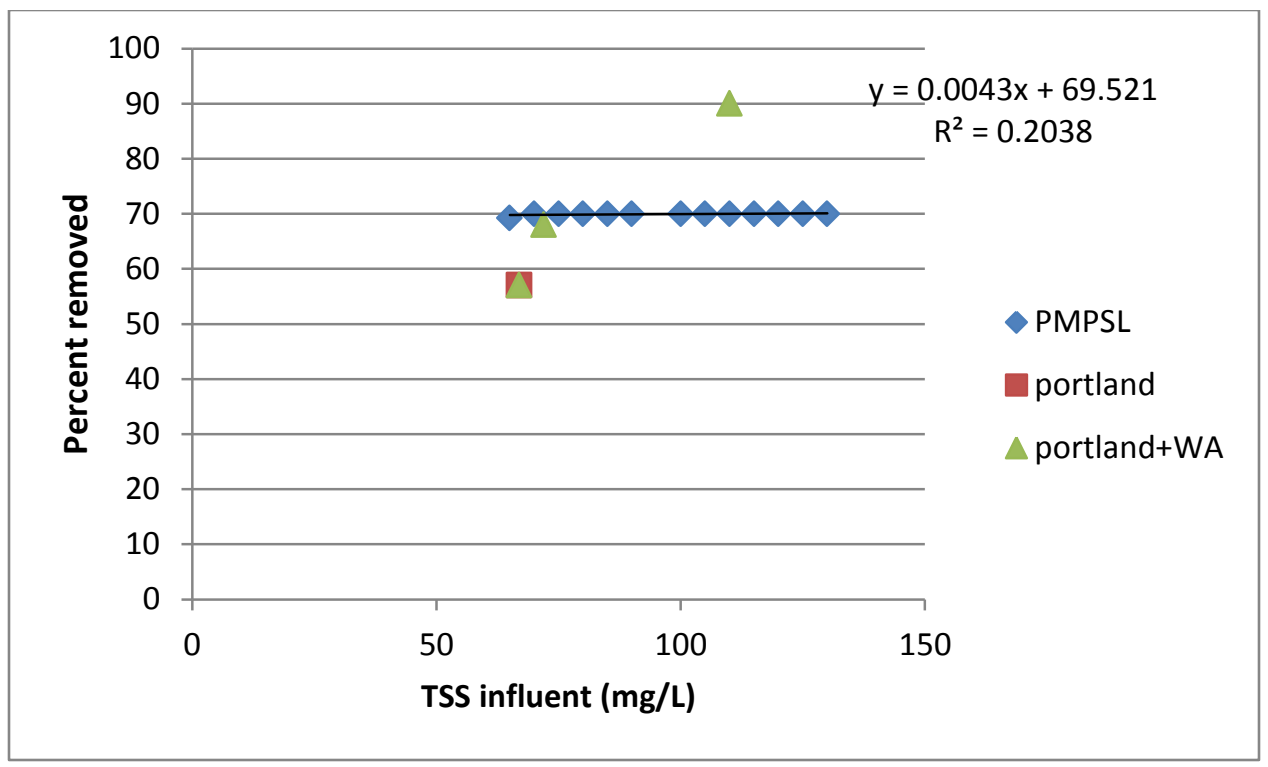

Figure 26: Part II of the Portland's Modified Performance standard Line

Table 15: RMSE and Bias results for acceptable events by Portland in part II of Portland's modified performance standard line

\begin{tabular}{lcccc}
\hline $\begin{array}{l}\text { TSS } \\
\text { influent }\end{array}$ & $\begin{array}{c}\text { Efficiency } \\
\text { (observation) }\end{array}$ & $\begin{array}{c}\text { Efficiency } \\
\text { (simulation) }\end{array}$ & $\begin{array}{c}\text { RMSE } \\
\text { (ob-sim) }\end{array}$ & $\begin{array}{c}\text { Bias } \\
\text { Obs-sim }\end{array}$ \\
\hline 66.9 & 57 & 69.54 & 157.22 & -12.54 \\
\hline RMSE: 12.54 & & & \\
Bias: $-21.99 \%$ & & & \\
\hline
\end{tabular}

Table 16: RMSE and Bias results for acceptable events by Portland and Washington in part II of Portland's modified performance standard line

\begin{tabular}{lllll}
\hline $\begin{array}{l}\text { TSS } \\
\text { influent }\end{array}$ & $\begin{array}{l}\text { Efficiency } \\
\text { (observation) }\end{array}$ & $\begin{array}{l}\text { Efficiency } \\
\text { (simulation) }\end{array}$ & $\begin{array}{l}\text { RMSE } \\
\text { (ob-sim) }\end{array}$ & $\begin{array}{l}\text { Bias } \\
\text { Obs-sim }\end{array}$ \\
\hline 66.9 & 57 & 69.53867 & 6.962579 & -2.63867 \\
72 & 68 & 69.5606 & 5.950672 & 2.4394 \\
110 & 90 & 69.724 & 1622.156 & 40.276 \\
\hline
\end{tabular}

RMSE: 23.35

Bias: $16.10 \%$ 
The simulation points for part II of Portland's Modified Performance standard Line followed this line:

$$
y=0.0043 x+69.521 \quad \text { (Equation 7) }
$$

Comparing the two bias results we can see that bias error for Portland events $(-21.99)<$ bias error for Washington+ Portland events (16.10). This is again indicating that adding the events accepted by State of Washington has actually improved the efficiency.

\section{Part III of Portland's Modified Performance Standard Line}

Part III of the Portland's Modified Performance standard Line was for TSS influents larger than $130 \mathrm{mg} / \mathrm{L}$.

The simulation points for part III of Portland's Modified Performance standard Line followed equation 6:

$$
y=5 E-07 x^{3}-0.0007 x^{2}+0.3446 x+37.237 \text { (Equation 8) }
$$

After comparing the simulation and observation points and comparing the two bias results for events allowed for Portland and events approved by Washington state, the result is: bias error for Portland events $(-3.1307)<<$ bias error for Washington+ Portland events $(-2.7296)$. These results indicate that the events accepted by State of Washington have improved the efficiency. 


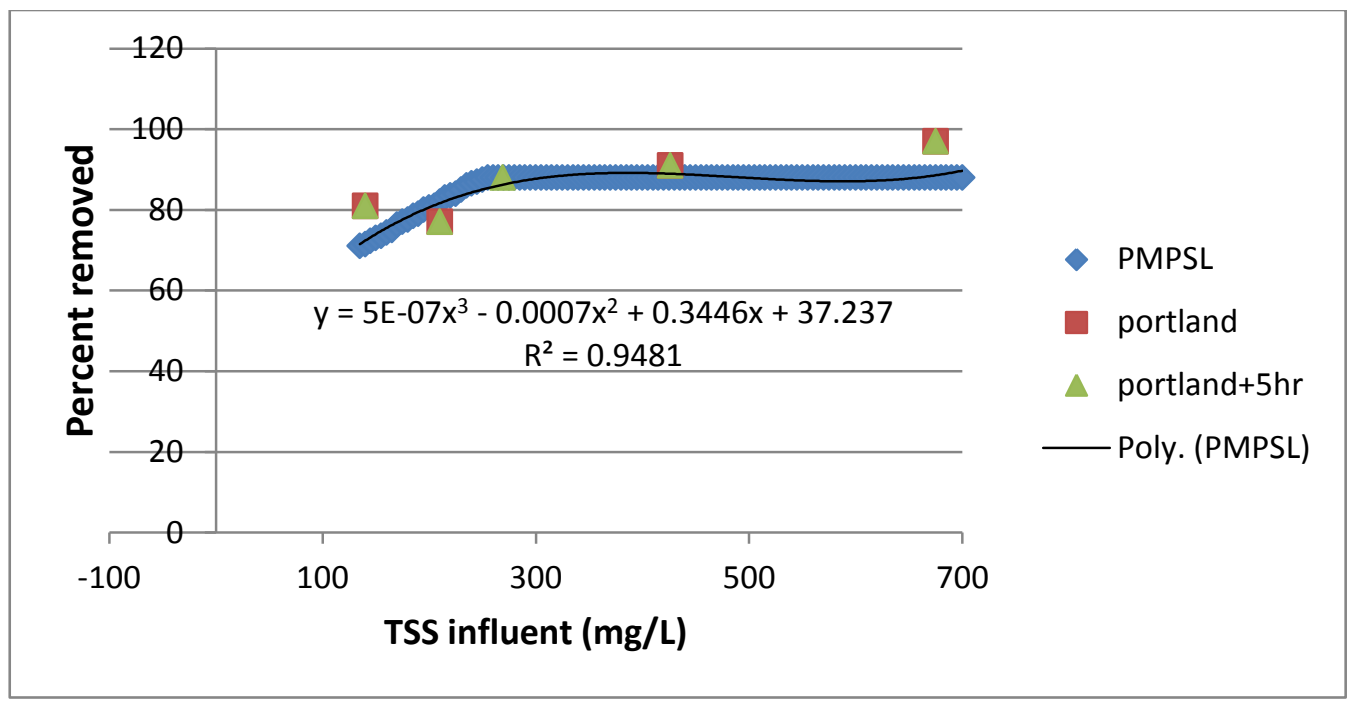

Figure 27: Part III of the Portland's Modified Performance standard Line

Table 17: RMSE and Bias results for acceptable events by Portland in part III of Portland's modified performance standard line

\begin{tabular}{lllll}
\hline $\begin{array}{l}\text { TSS } \\
\text { inflent }\end{array}$ & $\begin{array}{l}\text { efficiency } \\
\text { (observation) }\end{array}$ & $\begin{array}{l}\text { efficiency } \\
\text { (simulation) }\end{array}$ & $\begin{array}{l}\text { RMSE } \\
\text { (ob-sim) }\end{array}$ & $\begin{array}{l}\text { Bias } \\
\text { Obs-sim }\end{array}$ \\
\hline 675 & 97 & 104.6779 & 58.95072 & -7.67794 \\
426 & 91 & 95.65779 & 21.69499 & -4.65779 \\
210 & 77 & 83.3635 & 40.49413 & -6.3635 \\
140 & 81 & 73.133 & 61.88969 & 7.867 \\
\hline
\end{tabular}

RMSE: 6.76

Bias: $-3.13 \%$

Table 18: RMSE and Bias results for acceptable events by Portland and Washington in part III of Portland's modified performance standard line

\begin{tabular}{lcccc}
$\begin{array}{l}\text { TSS } \\
\text { influent }\end{array}$ & $\begin{array}{c}\text { Efficiency } \\
\text { (observation) }\end{array}$ & $\begin{array}{c}\text { Efficiency } \\
\text { (simulation) }\end{array}$ & $\begin{array}{c}\text { RMSE } \\
\text { (ob-sim) }\end{array}$ & $\begin{array}{c}\text { Bias } \\
\text { Obs-sim }\end{array}$ \\
\hline 675 & 97 & 104.6779 & 58.95072 & -7.67794 \\
426 & 91 & 95.65779 & 21.69499 & -4.65779 \\
210 & 77 & 83.3635 & 40.49413 & -6.3635 \\
140 & 81 & 73.133 & 61.88969 & 7.867 \\
269 & 88 & 89.01425 & 1.028712 & -1.01425 \\
\hline
\end{tabular}

RMSE: 5.13

Bias: $-2.73 \%$ 
From State of Washington's approved events for higher than $130 \mathrm{mg} / \mathrm{L}$ TSS influents, one event was not used because there was an internal bypass during the treatment to avoid overflow, so not all the inflow water was treated.

All these results indicate that the Washington State's approved events have actually helped with the efficiency of the device.

\section{Differences between Land Covers}

Land form is different from land use, where land form features include soil texture, soil type (mineral or organic), surficial geology, physiography (slope, drainage density), and soil chemistry. ((Sonzogni et al., 1980))

Even though land form is not a factor in Appendix B (SWMM), I think that it is important to consider it, especially for the places with certain conditions. Particle size distribution in soil is one of the most important features of land forms to consider. If the soil texture is more of a fine grain, clay soil, then the runoff spreads more comparing to a coarse sandy soil. Clay sized particles usually store more pollutants because of their chemical and physical properties ((Sonzogni et al., 1980),(Makepeace et al., 1995)). Another property could be the slope, a steep slope means a more pollutant runoff.

In the previous sections, it was talked about the influence of land cover on the different pollution components. One the most important conclusions which is 
also very useful was that out of many different studies it was shown that land cover does not have much effect on the amount of TSS in runoff. Of course, those conclusions were achieved from studying on a large number of sites, and different land covers and one of the main reasons for why this conclusion is not always achieved was based on the reason that there were not enough tests done, on not enough sites with different land covers. Although this argument logical, it was not a bad idea to check these result on the very little data that was available from one of the vendors. This data was sent from one vendor on two different sites, with two different land covers. Of course, one of the rules of accepting a vendor is that they have data from three sites with at least two different land uses.

The vendor had done their experiment in Washington State. It is notable to remind that the land cover and the climate in Washington and Portland are very similar. One of the sites was a commercial retail facility in Vancouver Washington called Heritage Marketplace and the other was near a roadway Everett Washington in Lake Stevens. There was about 21 events from the first site and 13 events from the second site. The average efficiency was put in a t-test. All the events were used except for one which had an average efficiency of 1, and was considered an outlier. This t-test was done in MATLAB. The null hypothesis was that sample means are the same within $95 \%$ of confidence interval. If the result of $h$ equals 0 , then we could not reject the null hypothesis and thus accepted that the means of the two sample groups were the same, indicating that there was not that much difference in the two land uses. 
The samples were inserted into the t-test and the test result showed that $\mathrm{h}$ was equal to 0 , with a p-value of 0.0759 .

This meant that the t-test was unable to reject the null hypothesis; and that there was no difference between the two land covers for this specific vendor. 


\section{Chapter 6: Conclusion}

The main purpose of this work was to analyze the vendor submission guide of the stormwater treatment manual of the city of Portland. Our specific goals are in two areas, 1) compare the criteria for acceptable storm event in the manual to the actual frequency of such event in Portland, and 2) compare the stormwater testing criteria and results for Washington State with Portland test standards.

The information gathered includes: 31 years of hourly precipitation data from 66 gauges throughout Portland as well as data from two different vendors which included the hydrologic properties of the events and the TSS influent and effluent. Also available were the requirements and rules intended for city of Portland and state of Washington. The two sets of rules were compared and it was found that, while in most cases, Washington has more restrictions on the treatment of the data, Portland has more rigid restrictions on the types of storm events that can be used and how to accept a given rainfall event. The two stormwater treatment requirements were compared rule by rule.

One of our main findings was that the rule governing samples seasonality may be excessively restrictive on data gathering. The Portland rule states that no more than $70 \%$ of data could be in the wet or dry season. Historical precipitation data were fitted by this rule and the other duration and intensity rules which applied to rainfalls in order to accept them as a suitable event. We found that applying the seasonality $(30 \%-70 \%)$ rule considerably lower's the number of 
available events per gauge. It is particularly difficult to obtain sufficient summer events and we found that the rule rather arbitrarily filters out a great many otherwise useful storms for device testing. This injects great uncertainty and much higher testing costs for vendor, with no apparent benefit to the city.

We also used regression techniques and a Poisson distribution analysis to devise a method for estimating the number of usable events in a given year, based on total precipitation. This will help the city know with a 95\% confidence interval how many number of events should be expected in a testing year to be used by vendors by knowing the average annual rainfall.

Our studies of land use and land form demonstrated that, when considering TSS, land use does not have an effect on the concentration of TSS based on the available data. From this we conclude that for the data the study was prepared on testing rules mandating data from multiple land uses are not very useful in improving test reliability and simply add unnecessary costs to vendors.to get a more thorough result, more data is needed.

The study then checked the result of changing some of the rules concerning the rain fall. We found that, after the $30 \%-70 \%$ rule, the rule that there should be at least a six hour duration of no rain event before and after an event used in testing. Using the historical precipitation data, this six hour restriction was reduced to five hours, four hours, three hours and two hours. By eliminating each one-hour interval we found there was a considerable increase in the number of accepted events. We 
recommend that the city strongly considers reducing the interval period to four or five hours to expand the basis of useful test events.

Another part of this thesis focused on increasing the number of events available per year by merging any two events separated by a 1 hour or less of no rain inside a rain event segment which otherwise follows all the testing rules. We concluded that this data adjustment significantly increases the number of accepted events with no obvious loss of quality in the results received by the city.

The Portland performance standard line for TSS was also used in order to check the efficiency of the events accepted by Portland and compare them to the events accepted by Washington State under their testing guidelines. The line was divided into three parts for modeling purposes. The events which were within each influent concentration range for both Portland and Washington were extracted. Then the TSS treatment efficiencies reported were checked to see whether using the data accepted by Washington will actually increase the overall reported efficiency of a device. We concluded that for all the three parts of the trisected Portland modified standard line, the Washington data had a higher efficiency in comparison to the data accepted by Portland.

This leads us to conclude that most Washington test data should be considered useful by Portland in evaluating the performance of a device. This thesis recommends more data be obtained by Portland in order to facilitate any further work. It is recommended that Portland ask the vendors for more treatment data. It 
is also recommended that the vendors present data which accepts Portland rules as well as data which follow only the Washington rules. More data will give city regulations a more precise and complete set of results for evaluating, and if necessary, modifying the stormwater-device testing protocol. It is also good if the 31 years of data were clustered into different section of land uses to check the effects of land use on the data as well. 


\section{References}

http://or.water.usgs.gov/non-usgs/bes/raingage info/clickmap.html.

http://www.portlandonline.com.

http://www.wsdot.wa.gov/Environment/WaterQuality/StormwaterPermitQandA.htm. (2008).Stormwater Management Manual; Revision-4. City of Portland.

Armstrong, L. J. \&Consultants, W. C. (1994). Contribution of heavy metals to storm water from automotive disc brake pad wear. Woodward-Clyde Consultants.

Athayde, D. N. (1984). Results of the nationwide urban runoff program. National Technical Information Service.

Beckwith, P., Ellis, J., Revitt, D. \&Oldfield, F. (1986). Heavy metal and magnetic relationships for urban source sediments. Physics of the Earth and Planetary Interiors 42(1): 67-75.

Bruland, K. W., Bertine, K., Koide, M. \&Goldberg, E. D. (1974). History of metal pollution in southern California coastal zone. Environmental Science \& Technology 8(5): 425-432.

Carleton, J., Grizzard, T., Godrej, A. \&Post, H. (2001). Factors affecting the performance of stormwater treatment wetlands. Water Research 35(6): 1552-1562.

Chebbo, G. (1999). Characterisation of urban runoff pollution in Paris. Wat Sci Tech 39(2): 1-8.

Chiew, F. H. S., Mudgway, L. B. \&McMahon, T. A. (1997). Urban stormwater pollution. CRC for Catchment Hydrology.

Clark, S. E. \&Pitt, R. (2008). Comparison of stormwater solids analytical methods for performance evaluation of manufactured treatment devices. Journal of Environmental Engineering 134(4): 259-264.

Dechesne, M., Barraud, S. \&Bardin, J. P. (2004). Spatial distribution of pollution in an urban stormwater infiltration basin. Journal of contaminant hydrology 72(1): 189-205.

Ellis, J. B., Harrop, D. O. \&Revitt, D. M. (1986). Hydrological controls of pollutant removal from highway surfaces. Water Research 20(5): 589-595.

Fabricius, K. E. (2005). Effects of terrestrial runoff on the ecology of corals and coral reefs: review and synthesis. Marine pollution bulletin 50(2): 125-146.

Hoppin, M. (2008).Guidance for Evaluating Emerging Stormwater Treatment Technologies, Technology Assessment Protocol - Ecology (TAPE) Olympia, Washington: Washington State Department of Ecology.

Howie, D. C. (2011).Technical Guidance Manual for Evaluating Emerging Stormwater Treatment Technologies, Technology Assessment Protocol - Ecology (TAPE) Olympia, Washington: Washington State Department of Ecology.

Jurries, D. (2003). Biofilters (Bioswales, Vegetative Buffers, \& Constructed Wetlands) for Storm Water Discharge Pollution Removal. Quality, S. o. OD o. E.(Ed.). Kidd, R., y N. Colletta.(1980). Tradition for Development: Indigenous Structures and Folk 
Media in Non-Formal Education. Bonn: German Foundation for International Development.

Makepeace, D. K., Smith, D. W. \&Stanley, S. J. (1995). Urban stormwater quality: summary of contaminant data. Critical Reviews in Environmental Science and Technology 25(2): 93-139.

Minton, G. R. (2002). Stormwater treatment: Biological, chemical, and engineering principles. Resource Planning Associates.

Novotny, V., Olem, H. \&OIness, A. (1994). Water quality: prevention, identification, and management of diffuse pollution. Van Nostrand Reinhold New York.

Passeport, E., Hunt, W. F., Line, D. E., Smith, R. A. \&Brown, R. A. (2009). Field study of the ability of two grassed bioretention cells to reduce storm-water runoff pollution. Journal of Irrigation and Drainage Engineering 135(4): 505-510.

Pitt, R., Field, R., Lalor, M. \&Brown, M. (1995). Urban stormwater toxic pollutants: assessment, sources, and treatability. Water Environment Research 67(3): 260275.

PROTECTION, E. (2007). Evaluation of Current Stormwater Design Criteria within the State of Florida.

Sonzogni, W. C., Chesters, G., Coote, D., Jeffs, D., Konrad, J., Ostry, R. \&Robinson, J. (1980). Pollution from land runoff. Environmental Science \& Technology 14(2): 148-153.

Taebi, A. \&Droste, R. L. (2004). First flush pollution load of urban stormwater runoff. Journal of Environmental Engineering and Science 3(4): 301-309.

Tsihrintzis, V. A. \&Hamid, R. (1997). Modeling and management of urban stormwater runoff quality: A review. Water Resources Management 11(2): 136-164.

USEPA (1983).Results of the nationwide urban runoff program. Vol. PB84185552Washington, D.C.

USEPA (1984).Process design manual: land treatment of municipal wastewater, supplement on rapid infiltration and overland flow. Vol. EPA 625/1-81013aWashington, D.C.

Weibel, S., Anderson, R. J. \&Woodward, R. L. (1964). Urban land runoff as a factor in stream pollution. Journal (Water Pollution Control Federation): 914-924.

Wong, T., Breen, P. F. \&Lloyd, S. D. (2000). Water sensitive road design: design options for improving stormwater quality of road runoff. CRC for Catchment Hydrology. 


\section{Appendix - more additional information}

\section{Sample Data Collection Sheet}

\section{Field Site 1}

Test 1= 10 sub-samples: ave. influent conc.=_; ave. effluent conc. $=$ __ ;efficiency $=$

Test $2=10$ sub-samples: ave. influent conc.=__; ave. effluent conc. $=\ldots$ _efficiency $=$

Test $3=10$ sub-samples: ave. influent conc.=_; ave. effluent conc. $=\ldots$ _efficiency $=$

Test $4=10$ sub-samples: ave. influent conc.=__; ave. effluent conc. $=$ __ ;efficiency $=$

Test $5=10$ sub-samples: ave. influent conc.=__; ave. effluent conc. $=\ldots$ _efficiency $=$

\section{Field Site 2}

Test $1=10$ sub-samples: ave. influent conc.=__; ave. effluent conc. $=$ __ ;efficiency $=$

Test $2=10$ sub-samples: ave. influent conc.=__; ave. effluent conc. $=\ldots$ _efficiency $=$

Test $3=10$ sub-samples: ave. influent conc.=__; ave. effluent conc. $=\ldots \ldots$ _efficiency $=$

Test $4=10$ sub-samples: ave. influent conc.=_; ave. effluent conc. $=\ldots$ _efficiency $=$

Test $5=10$ sub-samples: ave. influent conc.=__; ave. effluent conc. $=\ldots$ _efficiency $=$

\section{Field Site 3}

Test $1=10$ sub-samples: ave. influent conc.=__; ave. effluent conc. $=$ ___efficiency $=$

Test $2=10$ sub-samples: ave. influent conc. $=\ldots$; ave. effluent conc. $=\ldots$ _ ;efficiency $=$

Test $3=10$ sub-samples: ave. influent conc.=__; ave. effluent conc. $=\ldots$ _efficiency $=$

Test $4=10$ sub-samples: ave. influent conc.=__; ave. effluent conc. $=$ __ ;efficiency $=$

Test $5=10$ sub-samples: ave. influent conc.=__; ave. effluent conc. $=$ __ ;efficiency $=$

\section{Laboratory studies with real stormwater}


Test 1= 10 sub-samples: ave. influent conc. $=\ldots$; ave. effluent conc.$=$

Test $2=10$ sub-samples: ave. influent conc. $=\_$; ave. effluent conc. $=$

Test $3=10$ sub-samples: ave. influent conc. $=\_$; ave. effluent conc. $=$

Test $4=10$ sub-samples: ave. influent conc. $=\_$; ave. effluent conc. $=\ldots$ _efficiency $=$

Test $5=10$ sub-samples: ave. influent conc. $=\_$; ave. effluent conc. $=$

Test $6=10$ sub-samples: ave. influent conc. $=\_$; ave. effluent conc. $=$

Test $7=10$ sub-samples: ave. influent conc. $=\_$; ave. effluent conc. $=$

Test $8=10$ sub-samples: ave. influent conc. $=\ldots$; ave. effluent conc. $=$

\section{Laboratory studies with real stormwater}

Test $1=10$ sub-samples: ave. influent conc. $=\_$; ave. effluent conc $=$ ___ $;$ efficiency $=$

Test $2=10$ sub-samples: ave. influent conc. $=\_$; ave. effluent

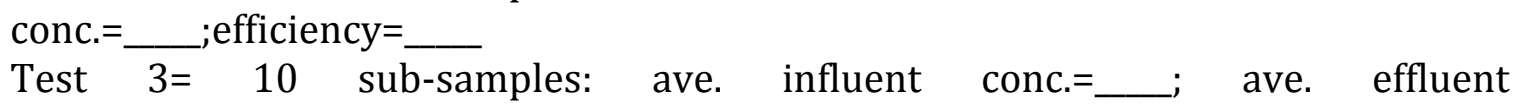
conc. $=$

Test $4=10$ sub-samples: ave. influent conc. $=\ldots$; ave. effluent $\begin{array}{ll}\text { conc. }=\_ \text {_efficiency }=\text { } \\ \text { Test } 5= & 10 \text { sub-samples: ave. influent } \text { conc. }=\_; \text {ave. effluent }\end{array}$ conc. $=\_$_efficiency $=$

Test $6=10$ sub-samples: ave. influent conc. $=\ldots ;$ ave. effluent conc $=$ _

Test $7=10$ sub-samples: ave. influent conc. $=\ldots$; ave. effluent conc. $=$

\section{Treatment Efficiency}

Method \#1: Removal in each storm calculated as:

100(flow-weighted influent concentration - flow-weighted effluent concentration) / flow-weighted influent concentration 
Method \#2: Aggregate removal of the storms sampled as:

$100(\mathrm{~A}-\mathrm{B}) / \mathrm{A}$

Where: $\mathrm{A}=$ (influent concentration Storm 1)(flow of Storm 1) + (influent concentration of Storm 2)(flow of Storm 2) +...(influent concentration of Storm $\mathrm{N}$ )(flow of Storm N)

$B=($ effluent concentration of Storm 1)(flow of Storm 1) + (effluent concentration of Storm 2)(flow of Storm 2) +...(effluent concentration of Storm N)(flow of Storm N)

Where concentrations are flow-weighted, and flow = average storm flow or total storm volume (vendor's choice).

Method \#3: Efficiency based on geometric mean:

$100(\mathrm{~A}-\mathrm{B}) / \mathrm{A}$

Where: A = Geometric mean of all products of flow-weighted influent concentration times average storm flow or total storm volume.

$\mathrm{B}=$ Geometric mean of all products of flow-weighted effluent concentration times average storm flow or total storm volume.

Method \#4: Removal in each storm calculated as:

Efficiency $=100$ (Captured load mass) $/$ (Influent load mass over entire storm)

Where: Captured load mass = Mass of accumulated TSS in the treatment facility during testing period

Influent load mass over entire storm $=$ Flow-weighted influent concentration times total storm volume through facility, or for laboratory tests with spiked water, total mass of added TSS. 


\section{Portland Gauge Information}

\begin{tabular}{|c|c|c|c|}
\hline $\begin{array}{c}\text { Gaugen } \\
\text { umber }\end{array}$ & station_name & address & $\begin{array}{l}\text { location_de } \\
\text { scription }\end{array}$ \\
\hline 1 & Ankeny Fire Station & 55 SW Ash & $\begin{array}{l}\text { SW Ash \& } \\
\text { Front }\end{array}$ \\
\hline 2 & Skyline School & 11536 NW Skyline & $\begin{array}{l}\text { NW Skyline } \\
\text { at NW } \\
\text { Brooks } \\
\text { Road }\end{array}$ \\
\hline 3 & Sauvies Island School & 14445 NW Charlton Rd & \\
\hline 3 & Sauvies Island School & 14445 NW Charlton Rd & \\
\hline 4 & Sylvania PCC & 12000 SW 49th Ave & \\
\hline 6 & Mt. Tabor Yard & 6437 SE Division & $\begin{array}{l}\text { Park } \\
\text { bureau } \\
\text { warehouse } \\
\text { on Division }\end{array}$ \\
\hline 7 & Hayden Island Pump Station & 1740 N Jantzen Beach CTR & \\
\hline 9 & $\begin{array}{l}\text { PDX E Business Park Pump } \\
\text { Station }\end{array}$ & 8599 NE Alderwood Road & \\
\hline 10 & Collins View School & 9806 SW Boones Ferry Road & $\begin{array}{l}\text { Renamed } \\
\text { to } \\
\text { Riverdale } \\
\text { School }\end{array}$ \\
\hline 12 & Fernwood School & 3255 NE Hancock & \\
\hline 14 & Kelly School & 9030 SE Cooper St & \\
\hline 20 & Gresham Fire Station & 1550 NW Eastman Parkway & \\
\hline 21 & Holgate Pump Station & 4507 SE 136th Ave & \\
\hline 41 & Vernon School & 2044 NE Killingsworth & \\
\hline 48 & Open Meadows School & 7602 N Emerald & $\begin{array}{l}\text { Originally } \\
\text { known as } \\
\text { Columbia } \\
\text { Boys \& } \\
\text { Girls Club }\end{array}$ \\
\hline 58 & Bonny Slope School & 10351 NW Thompson Rd & \\
\hline 64 & Harney Pump Station & 2033 SE Harney St & \\
\hline 72 & Fremont Pump Station & 2777 NE Fremont Dr. & \\
\hline 82 & Shipyard Pump Station & 11966 N Edison & \\
\hline 89 & Vermont Hills Pump Station & 5730 SW Idaho St. & \\
\hline 107 & Columbia IPS & 5001 N Columbia Blvd & \\
\hline 108 & Ankeny Pump Station & 30 S.W. Front Ave & \\
\hline 111 & Airport Way \#2 Pump Station & 14614 NE Airport Way & \\
\hline 115 & Mallory Pump Station & 8030 NE Mallory & \\
\hline 117 & Albina Pump Station & 2920 N Larrabee Ave & \\
\hline 120 & Thomas Pump Station & 4026 SW Macadam Ave & \\
\hline 121 & Yeon Pump Station & 3395 NW Yeon Ave & \\
\hline 122 & Swan Island Pump Station & 2600 N Going St & \\
\hline 125 & Guilds Lake Pump Station & 7110 NW Front Ave & \\
\hline 130 & Linnton Pump Station & 10909 NW Front Ave & \\
\hline 137 & Marine Drive Pump Station & 7305 N Marine Dr. & \\
\hline
\end{tabular}




\begin{tabular}{|c|c|c|c|}
\hline 139 & Simmons Pump Station & 16001 N Simmons Rd & \\
\hline 144 & Columbia STP & 5001 N Columbia Blvd & $\begin{array}{l}\text { On roof of } \\
\text { screen } \\
\text { house }\end{array}$ \\
\hline 145 & Pleasant Valley School & 17625 SE Foster Rd. & \\
\hline 146 & Cottrell School & $\begin{array}{l}39225 \text { SE Proctor Rd. } \\
\text { Gresham }\end{array}$ & \\
\hline 147 & Skyline Fire Station & 8031 NW Skyline Blvd & \\
\hline 152 & Beaumont School & 4043 NE Fremont St & \\
\hline 153 & Cascade PCC & 705 N Killingsworth & \\
\hline 153 & Cascade PCC & 705 N Killingsworth & \\
\hline 159 & PDX Post Office Pump Station & & $\begin{array}{l}\text { Portland } \\
\text { Internation } \\
\text { al airport } \\
\text { East of US } \\
\text { Post Office }\end{array}$ \\
\hline 160 & WPCL & 6543 N Burlington Ave & $\begin{array}{l}\text { Water } \\
\text { Pollution } \\
\text { Control } \\
\text { Laboratory }\end{array}$ \\
\hline 161 & Sylvan School & 1849 SW 58th & $\begin{array}{l}\text { German- } \\
\text { American } \\
\text { school of } \\
\text { Portland }\end{array}$ \\
\hline 162 & Grant Park Unsumped & $1907 \mathrm{NE} 45^{\text {th }}$ & $\begin{array}{l}\text { NE Sandy } \\
\text { Blvd \& NE } \\
\text { 45th on } \\
\text { Rose City } \\
\text { Park } \\
\text { Presbyteria } \\
\text { n Church }\end{array}$ \\
\hline 164 & SW 12th \& Clay & & Ecoroof \\
\hline 167 & Terminal 4 & 11040 N Lombard & $\begin{array}{l}\text { Port of } \\
\text { Portland } \\
\text { Terminal } 4\end{array}$ \\
\hline 167 & Terminal 4 & 11040 N Lombard & $\begin{array}{l}\text { Port of } \\
\text { Portland } \\
\text { Terminal } 4\end{array}$ \\
\hline 171 & Sunnyside School & 3421 SE Salmon & \\
\hline 172 & Maplewood Elementary School & 7425 SW 52nd & \\
\hline 173 & Metro Learning Center & 2033 NW Glisan & \\
\hline 174 & Arleta School & 5109 SE 66th Ave & \\
\hline 175 & Glencoe School & 825 SE 51st Ave & \\
\hline 181 & Multnomah Raingauge & 501 SE Hawthorne Blvd & \\
\hline 192 & Children's Museum & 4015 SW Canyon Rd. & \\
\hline 193 & Astor School & 5601 N Yale St & \\
\hline 204 & $\begin{array}{l}\text { Swan Island CSO Pump } \\
\text { Station }\end{array}$ & & \\
\hline 213 & Madison School & 2735 NE 82nd & \\
\hline 214 & OPB Raingauge & & \\
\hline 217 & Park SE Yard & 5669 SE 136th & \\
\hline 300 & West T.V. School & 8800 SW Leahy Road & \\
\hline 311 & Bridlemile School & & \\
\hline
\end{tabular}




\begin{tabular}{|r|l|l|}
\hline 312 & Chapman School & \\
\hline 313 & Facilities Planning & \\
\hline 314 & Fire Station Number 1 & \\
\hline 315 & Fire Station Number 9 & \\
\hline 316 & Fire Training Center & \\
\hline 317 & Fremont Drive (Old) & \\
\hline 318 & Fulton Tr Number 6 & \\
\hline 319 & Holy Family S & \\
\hline 320 & Kliever Army & \\
\hline 321 & Mt Tabor Tst & \\
\hline 322 & NE 33 & \\
\hline 323 & Powell Shops & \\
\hline 324 & Sacajawea S & \\
\hline & & \\
\hline
\end{tabular}




\section{Current Approved List of Vendors by City of Portland as of April 2005}

\begin{tabular}{|c|c|}
\hline $\begin{array}{l}\text { Approved for use in Public Right-of-Way } \\
\text { (systems maintained by the City) }\end{array}$ & $\begin{array}{l}\text { Approved for use on } \\
\text { Private Property } \\
\text { (systems maintained } \\
\text { privately) }\end{array}$ \\
\hline $\begin{array}{l}\text { 1. Stormwater Management Stormfilter (vault-type w/multiple } \\
\text { filter cartridges). Approved for standalone } 1 \text { use at } 15 \mathrm{gpm} \\
\text { treatment flow per cartridge. }\end{array}$ & $\begin{array}{lr}1 . & \text { Stormwater } \\
\text { Management } & \text { Stormfilter } \\
\text { (vault-type } \quad \text { w/multiple } \\
\text { filter } \quad \text { cartridges). } \\
\text { Approved for stand-alone } 1 \\
\text { use at } 15 \text { gpm treatment } \\
\text { flow per cartridge. }\end{array}$ \\
\hline $\begin{array}{l}\text { 2. Stormwater Management Stormfilter (precast } 48 \text { " manhole } \\
\text { w/ } 2 \text { filter cartridges). Approved for standalone } 1 \text { use at } 15 \text { gpm } \\
\text { treatment flow per cartridge. }\end{array}$ & $\begin{array}{l}2 . \\
\text { Management Stormwater } \\
\text { (precast 48" or } 60 " \\
\text { manhole } \\
\text { Approved for stand-alone } 1 \\
\text { use at } 15 \text { gpm treatment } \\
\text { flow per cartridge. }\end{array}$ \\
\hline $\begin{array}{l}\text { 3. Stormwater Management Stormfilter (precast } 60 \text { " manhole } \\
\text { w/3 filter cartridges). Approved for standalone } 1 \text { use at } 15 \text { gpm } \\
\text { treatment flow per cartridge. }\end{array}$ & $\begin{array}{l}3 . \quad \text { Stormwater } \\
\text { Management Stormfilter } \\
\text { (catch basin model). } \\
\text { Approved for stand-alone } 1 \\
\text { use at } 15 \text { gpm treatment } \\
\text { flow per cartridge. }\end{array}$ \\
\hline $\begin{array}{l}\text { 4. CDS Technologies. Approved for pretreatment } 2 \text { as a } \\
\text { component of a treatment train. }\end{array}$ & $\begin{array}{l}\text { 4. CDS Technologies. } \\
\text { Approved for pretreatment } \\
2 \text { as a component of a } \\
\text { treatment train. }\end{array}$ \\
\hline $\begin{array}{l}\text { 5. Downstream Defender. Approved for } \\
\text { Pretreatment } 2 \text { as a component of a treatment train. }\end{array}$ & $\begin{array}{l}\text { 5. Downstream Defender. } \\
\text { Approved for pretreatment } \\
2 \text { as a component of a } \\
\text { treatment train. }\end{array}$ \\
\hline $\begin{array}{l}\text { 6. Vortechnics Vortechs System. Approved for Pretreatment } 2 \text { as } \\
\text { a component of a treatment train. }\end{array}$ & $\begin{array}{l}\text { 6. Vortechnics Vortechs } \\
\text { System. Approved for } \\
\text { Pretreatment } 2 \text { as a } \\
\text { component of a treatment } \\
\text { train. }\end{array}$ \\
\hline $\begin{array}{l}\text { 7. Stormceptor. Approved for pretreatment } 2 \text { as a component of } \\
\text { a treatment train. }\end{array}$ & $\begin{array}{l}\text { 7. Stormceptor. Approved } \\
\text { for pretreatment } 2 \text { as a } \\
\text { component of a treatment } \\
\text { train. }\end{array}$ \\
\hline & $\begin{array}{l}8 . \text { Jensen Precast } \\
\text { Stormvault. Approved for } \\
\text { Pretreatment } 2 \text { as a } \\
\text { component of a treatment } \\
\text { train. }\end{array}$ \\
\hline
\end{tabular}




\section{Summary of Best Management Practices by City of Portland}

\begin{tabular}{|c|c|}
\hline BMP CATEGORY AND PURPOSE & CITY OF PORTLAND BMPS \\
\hline $\begin{array}{l}\text { Public Involvement (PI) } \\
\text { To inform and educate the public about the causes of } \\
\text { stormwater pollution, the effects on local streams and } \\
\text { rivers, and the need for stormwater management. To } \\
\text { encourage active participation in pollution reduction. }\end{array}$ & $\begin{array}{l}\text { PI-1: Implement public information, } \\
\text { education, involvement, and } \\
\text { stewardship activities that will } \\
\text { raise awareness, foster community } \\
\text { stewardship, and promote pollution } \\
\text { prevention and stormwater } \\
\text { management. }\end{array}$ \\
\hline $\begin{array}{l}\text { Operations and Maintenance (OM) } \\
\text { To implement operations and maintenance practices } \\
\text { for public streets, sewers, and other facilities to reduce } \\
\text { pollutants in discharges from the municipal separate } \\
\text { storm sewer system. }\end{array}$ & $\begin{array}{l}\text { OM-1: Operate and maintain } \\
\text { components of the municipal separate } \\
\text { storm sewer system (MS4) to remove } \\
\text { and prevent pollutants in discharges } \\
\text { from the MS4. } \\
\text { OM-2: Operate and maintain } \\
\text { components of public rights-of-way, } \\
\text { including streets, to remove and } \\
\text { prevent pollutants in discharges from } \\
\text { the municipal separate storm sewer } \\
\text { system. } \\
\text { OM-3: Operate and maintain other } \\
\text { City facilities and infrastructure (not } \\
\text { included in OM-1 or OM-2) to remove } \\
\text { and prevent pollutants in discharges } \\
\text { from the municipal separate storm } \\
\text { sewer system. }\end{array}$ \\
\hline $\begin{array}{l}\text { Industrial/Commercial Controls (IND) } \\
\text { To reduce and control the discharge of pollutants from } \\
\text { industrial and commercial facilities to the municipal } \\
\text { separate storm sewer system. }\end{array}$ & $\begin{array}{l}\text { IND-1: Implement the Industrial } \\
\text { Stormwater Management Program to } \\
\text { control the discharge of pollutants } \\
\text { from industrial and commercial } \\
\text { facilities to the municipal separate } \\
\text { storm sewer system. } \\
\text { IND-2: Provide education and } \\
\text { technical assistance to reduce } \\
\text { industrial and commercial pollutant } \\
\text { discharges to the municipal separate } \\
\text { storm sewer system. }\end{array}$ \\
\hline $\begin{array}{l}\text { Illicit Discharges Controls (ILL) } \\
\text { To identify, investigate, and, if appropriate, } \\
\text { control/eliminate illicit discharges and } \\
\text { nonstormwater discharges to the municipal separate } \\
\text { storm sewer system. }\end{array}$ & $\begin{array}{l}\text { ILL-1: Identify, investigate, control, } \\
\text { and/or eliminate illicit discharges } \\
\text { (illicit connections, illegal dumping, } \\
\text { and spills) to the municipal separate } \\
\text { storm sewer system. Evaluate and, if } \\
\text { appropriate, control non-stormwater } \\
\text { discharges to the municipal separate } \\
\text { storm sewer system. }\end{array}$ \\
\hline $\begin{array}{l}\text { New Development Standards (ND) } \\
\text { To prevent and mitigate pollutant discharges and } \\
\text { other water quality impacts associated with new } \\
\text { development and redevelopment during and after } \\
\text { construction. }\end{array}$ & $\begin{array}{l}\text { ND-1: Control erosion, sediment, and } \\
\text { pollutant discharges from active } \\
\text { construction sites. } \\
\text { ND-2: Implement and refine } \\
\text { stormwater }\end{array}$ \\
\hline
\end{tabular}




\begin{tabular}{|c|c|}
\hline & $\begin{array}{l}\text { requirements for new development } \\
\text { and redevelopment projects to } \\
\text { minimize pollutant discharges and } \\
\text { erosive stormwater flows. }\end{array}$ \\
\hline $\begin{array}{l}\text { Structural Controls (STR) } \\
\text { To implement structural modifications (constructed } \\
\text { facilities) to existing systems/development to reduce } \\
\text { pollutants in discharges from the municipal separate } \\
\text { storm sewer system. }\end{array}$ & $\begin{array}{l}\text { STR-1: Structurally modify } \\
\text { components of the storm drainage } \\
\text { system to reduce pollutant discharges. } \\
\text { Implement structural retrofits/ } \\
\text { improvements to existing development } \\
\text { to reduce pollutants in discharges from } \\
\text { the municipal separate storm sewer } \\
\text { system. }\end{array}$ \\
\hline $\begin{array}{l}\text { Natural Systems (NS) } \\
\text { To help preserve and restore the natural resources } \\
\text { and functions that prevents pollutants from entering } \\
\text { into and discharging from the municipal separate } \\
\text { storm sewer system. }\end{array}$ & $\begin{array}{l}\text { NS-1: Protect and restore natural } \\
\text { areas and vegetation to reduce } \\
\text { pollutants in discharges from the } \\
\text { municipal separate storm sewer } \\
\text { system. }\end{array}$ \\
\hline $\begin{array}{l}\text { Program Management (PM) } \\
\text { To ensure effective program management, } \\
\text { coordination, and reporting. }\end{array}$ & $\begin{array}{l}\text { PM-1: Conduct program management, } \\
\text { coordination, and reporting }\end{array}$ \\
\hline
\end{tabular}

